Florida International University FIU Digital Commons

6-29-2015

\title{
Policing Slavery: Order and the Development of Early Nineteenth-Century New Orleans and Salvador
}

Gregory K. Weimer

PhD Student, gweim001@fiu.edu

DOI: $10.25148 /$ etd.FIDC000107

Follow this and additional works at: https:// digitalcommons.fiu.edu/etd

Part of the Latin American History Commons, Legal Commons, Social History Commons, and the United States History Commons

\section{Recommended Citation}

Weimer, Gregory K., "Policing Slavery: Order and the Development of Early Nineteenth-Century New Orleans and Salvador" (2015). FIU Electronic Theses and Dissertations. 2192.

https://digitalcommons.fiu.edu/etd/2192 


\title{
FLORIDA INTERNATIONAL UNIVERSITY \\ Miami, Florida
}

\section{POLICING SLAVERY: ORDER AND THE DEVELOPMENT OF EARLY NINETEENTH-CENTURY NEW ORLEANS AND SALVADOR}

\author{
A dissertation submitted in partial fulfillment of the \\ requirements for the degree of \\ DOCTOR OF PHILOSOPHY \\ in \\ HISTORY \\ by \\ Gregory Kent Weimer
}

2015 
To: Dean Michael R. Heithaus

College of Arts and Sciences

The dissertation, written by Gregory Kent Weimer, and entitled Policing Slavery: Order and the Development of Early Nineteenth-Century New Orleans and Salvador, having been approved in respect to style and intellectual content, is referred to you for judgment.

We have read the dissertation and recommend that it be approved.

Victor Uribe-Uran

Matthew Mirow

Okezi Otovo

Alexandra Cornelius

Kirsten Wood, Major Professor

Date of Defense: June 29, 2015

The dissertation of Gregory Kent Weimer is approved.

$\begin{array}{r}\hline \begin{array}{r}\text { Dean Michael R. Heithaus } \\ \text { College of Arts and Sciences }\end{array} \\ \hline \begin{array}{r}\text { Dean Lakshmi N. Reddi } \\ \text { University Graduate School }\end{array}\end{array}$

Florida International University, 2015 
C Copyright 2015 by Gregory Kent Weimer

All rights reserved. 


\section{DEDICATION}

For my parents, whose support and inspiration have been essential to my academic career and my life. 


\section{ACKNOWLEDGMENTS}

During my doctoral work at Florida International University, my dissertation transformed from a narrowly-focused project on late eighteenth-century British naval impressment in American waters to a comparison of urban slavery in the United States and Brazil. The evolution of this dissertation has been both rewarding and daunting. I appreciate both the moral and financial support of Florida International University's History Department. I owe a multitude of people thanks for helping me along the way.

First and foremost I would like to thank my dissertation director, Kirsten Wood. Her mentorship and commitment to the project and its improvement will always be appreciated. I would also like to thank the other members of my committee, Alexandra Cornelius, Matthew C. Mirow, Okezi Otovo, and Victor Uribe. It has been a privilege to work with them. Their suggestions have shaped my dissertation over the past few years. I will also continue to benefit from their advice in future iterations of my dissertation.

I would like to thank my peers in the Florida International University's History Department. Amongst students and faculty in the History Department there is a strong sense of community and support. I am indebted to all the individuals who have encouraged me through my doctoral studies and the dissertation. Amanda Snyder and Carolina Zumaglini deserve special mention. I am grateful for both their comments on the dissertation and their mentorship over the past several years.

I would like to thank the Tinker Foundation, the Graduate School at Florida International University, and FIU's SIPA for their belief in my project and their financial support of its research. The Tinker Foundation provided funding for the preliminary research of the project. The generous funding by FIU's Dissertation Evidence 
Acquisition and Dissertation Year Fellowship allowed me to carry out much of the research and writing. The Morris and Anita Broad Fellowship provided funding to conduct research at the Library of Congress.

I also would like to thank the archivist and librarians at the Arquivo Público Do Estado da Bahia, the Arquivo Municipal do Prefectura do Salvador, the New Orleans Public Library—Louisiana Division, Tulane University—Louisiana Research Collection, University of New Orleans-Louisiana and Special Collections, Xavier University of New Orleans-University Archives, and the Library of Congress. 


\title{
ABSTRACT OF THE DISSERTATION \\ POLICING SLAVERY: ORDER AND THE DEVELOPMENT OF EARLY \\ NINETEENTH- CENTURY NEW ORLEANS AND SALVADOR
}

\author{
by \\ Gregory Kent Weimer \\ Florida International University, 2015 \\ Miami, Florida

\section{Professor Kirsten Wood, Major Professor}

My dissertation explores the development of policing and slavery in two early nineteenth-century Atlantic cities. This project engages regionally distinct histories through an examination of legislative and police records in New Orleans, Louisiana, and Salvador, Bahia. Through these sources, my dissertation holds that the development of the theories and practices that guided "public order" emerged in similar ways in these Atlantic slaveholding cities. Enslaved people and their actions played an integral role in the evolution of "good order" and its policing. Legislators created laws and institutions to police enslaved people and promote order. In these instances, local government policed slavery through the surveilling and arresting of enslaved people. By mid-century, the prerogative of policing slavery created a comprehensive bureaucratic structure that policed many individuals within the community, not just slaves.

In New Orleans and Salvador, slavery was an important part of policing, but not just in the sense we sometimes assume: as a panicked reaction to real or imagined slave rebellions. As the commercial and demographic development of cities created opportunities for enslaved people, local legislation and institutions formed an important 
part of policing slavery in New Orleans and Salvador. Local government officialsregional and municipal legislators-responded by passing laws that restricted not only where and how enslaved people worked and lived, but also the police that enforced these laws. Police forces, once created, interpreted and applied the laws passed by legislators. They surveilled and arrested individuals, and their actions sometimes triggered further legislative reforms. Thusly, police forces became representations of public well-being, particularly in relation to slavery. By mid-century, new conceptions of public order made the police an accepted part of urban slavery and urban life more generally in New Orleans and Salvador. At the same time, the police surveilled and arrested free people, not just enslaved people, in the name of promoting orderly slavery. 


\section{TABLE OF CONTENTS}

CHAPTER

PAGE

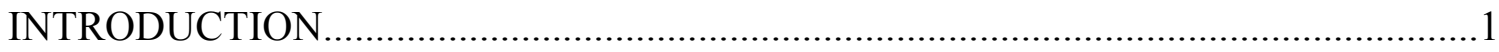

Part I.

The Development of Public Police Forces and the Prevention of Rebellions and

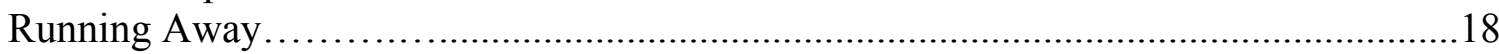

CHAPTER 1

New Orleans: 1804 - 1811.

CHAPTER 2

Salvador: 1823 - 1835 .

Part II.

Police Forces and the Policing of Slavery

CHAPTER 3

New Orleans: 1811 - 1815

CHAPTER 4

Salvador: 1835 - 1838

Part III.

Police Forces and the Policing of the Community.

CHAPTER 5

New Orleans: 1815 - 1835

CHAPTER 6

Salvador: 1838 - 1850

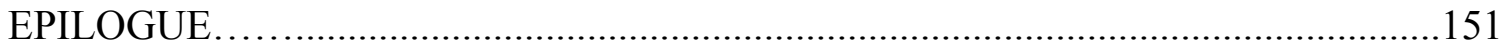

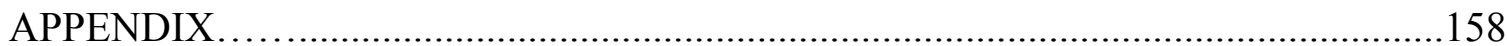

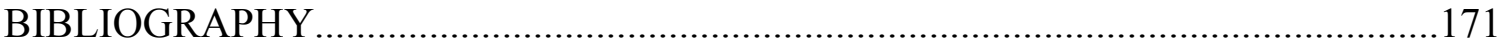

VITA 


\section{LIST OF TABLES}

TABLE

PAGE

1. The average exchange rate of milréis in U.S. cents from 1830 to $1890 \ldots \ldots \ldots \ldots \ldots \ldots \ldots . . . . . . . .17$

2. Occupations of Slaves within New Orleans' Inventories, between 1803 and $1840 \ldots . . .30$

3. Arrest Records from the Reports of the Captain of the Guards in $1809 \ldots \ldots \ldots \ldots \ldots \ldots . . . . . . .42$

4. Occupations of Slaves within Salvador's Inventories, between 1800 and $1840 \ldots \ldots \ldots . .53$

5. Juiz da Paz, Conceição da Praia, "Relação do Prezos.” September-October 1831.......65

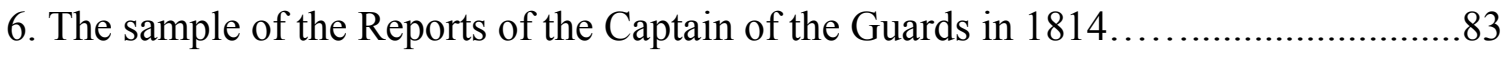

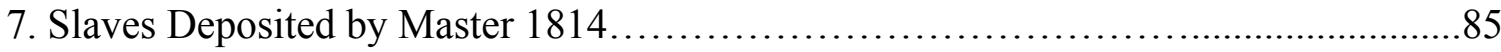

8. Total Arrests reported at São Bento, January - November 6, 1837.......................106

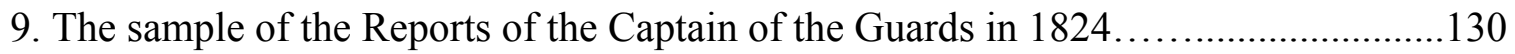

10. The sample of the Reports of the Captain of the Guards in $1834 \ldots \ldots \ldots \ldots \ldots \ldots \ldots \ldots . . . . . . . . . .130$

11. Slaves arrested at the behest of their masters in the Reports of the Captain of the

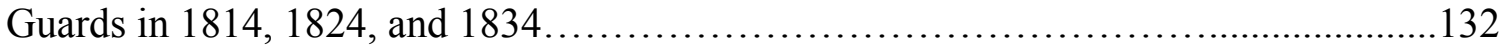

12. Breakdown of actions taken in relation to individuals within the Registro de Portaria from January to December 1847.

13. Crime statistics within a sample of the Registro de Portaria from January to December 1847 148 


\section{INTRODUCTION}

Ordering Urban Slave Society

Policing Slavery

\section{Introduction}

Over the past four decades, scholars of Brazil and Latin America have used police records in their historical studies. These sources have enabled a burgeoning scholarship that focuses on the role of institutions and crime in the development of cities and regions. Collectively, the literature has argued that police forces-militias, patrols, watches, justices of the peace, and civilian police units — enforced societal norms and restraints within society. At the same time, patterns of crime indicated how individuals resisted these societal norms. My dissertation moves beyond the dialectic of crime and restraint to a comparison between New Orleans and Salvador that examines the role that official conceptions of order played in the development of policing and slavery in the early nineteenth century. ${ }^{1}$

In cities throughout the Atlantic in the early nineteenth century, government and government institutions became responsible for the welfare of the community. State and

1. Patricia Ann Aufderheide, "Order and Violence: Social Deviance and Control in Brazil, 1780 - 1840," Ph.D. diss. (Minneapolis, MN: University of Minnesota, 1976); Leila Mezan Algranti, "Slave Crimes: The Use of Police Power to Control the Slave Population of Rio de Janeiro," Luso-Brazilian Review 25, no. 1 (1988): 27 - 48; Thomas H. Holloway, Policing Rio de Janeiro: Repression and Resistance in a 19th-Century City (Stanford, CA: Stanford University Press, 1993); Alexandra K. Brown, "On the Vanguard of Civilization': Slavery, the Police, and Conflicts Between Public and Private Power in Salvador Da Bahia, Brazil, 1835 - 1888," Ph.D. diss. (Austin, TX: University of Texas, 1998); Pablo Piccato, City of Suspects: Crime in Mexico City 1900 - 1931 (Durham, NC: Duke University Press, 2001). 
municipal authorities established and expanded many of the institutions that make up the modern era. Police forces, jails, courts, city councils, mayors, and other municipal services became accepted parts of everyday life. These institutions allowed government officials to define and then assume responsibility for many aspects of public welfare from private individuals, organizations, and groups. After the early nineteenth century, local government officials played a central role in the public life of society in cities throughout the Atlantic. ${ }^{2}$

My dissertation focuses precisely on the institutions responsible for ordering the urban slave societies in the nineteenth century: the legislators who created legal codes, and the police who interpreted and applied such legislation. While private individuals had been chiefly responsible for protecting public property in the eighteenth century, the demographic, economic, and physical expansion of cities prompted government authorities to assume responsibility for protecting the city and its inhabitants in the nineteenth century. Government officials theorized that the well-being of society depended upon government regulations and their enforcement. From these positions,

2. James Pitot, Observations of the Colony of Louisiana from 1769 to 1802, trans. Henry C. Pitot (Baton Rouge, LA: The Historic New Orleans Collection by the Louisiana State University Press, 1979), 29; Roberta Delson, "Land and Urban Planning: Aspects of Modernization in Early Nineteenth-Century Brazil," Luso-Brazilian Review 16, no. 2 (Winter 1979): 191 - 214; Walter Fraga Filho, Mendigos, Moleques e Vadios Na Bahia Do Século XIX (Salvador, BA: Editora da Universidade Federal da Bahia, 1996), 1 - 17; Dell Upton, Another City: Urban Life and Urban Spaces in the New American Republic (New Haven, CT: Yale University Press, 2008); Eric H. Monkkonen, America Becomes Urban: The Development of U.S. Cities and Towns, 1780 - 1980 (Oakland, CA: University of California Press, 1990), 5 - 6; Holloway, Policing Rio de Janeiro, 1; William J. Novak, The People's Welfare: Law and Regulation in Nineteenth Century America (Chapel Hill, NC: University of North Carolina Press, 1996), 1 - 13. 
authorities passed and enforced legislation intended to prevent crime and other forms of disorder. Thusly, legislators and the police became important aspect of everyday life within cities. ${ }^{3}$

Legislators (individuals in municipal, provincial, and state legislative bodies) sought to order cities in new ways in the nineteenth century. They created laws that protected various aspects of society. William Novak, a scholar of nineteenth-century law in the United States, has argued that these concerns divided into:

regulations for public safety and security (protecting the very existence of the population from catastrophic enemies like fires and invasion); the constructions of public economy (determining the rules by which the people would acquire and exchange food and goods); the policing of public space (defining common rights in roads, rivers, and public squares); all-important restraints on public morals (establishing the social and cultural conditions of public order); and the openended regulatory powers granted in public officials to guarantee public health (securing the population's well-being longevity, and productivity). ${ }^{4}$

Through laws in these related categories, legislators expressed their concerns for individuals and practices within society. These concerns manifest in legal codes that attempted to protect public welfare and good order. This legislation also suggested how officials sought to control individuals and practices that challenged the well-being of society, as they saw it.

Police forces (guards, police, patrols and watches and their commanders) were some of the most important groups that interpreted and applied legislation in Atlantic slaveholding cities. While courts, legislative bodies, executives, and military units all

3. Filho, Mendigos, Moleques e Vadios, 1 - 17; Monkkonen, America Becomes Urban, 5 - 6; Novak, The People's Welfare, 1 - 13.

4. Novak, The People's Welfare, $2-3$. 
had a role in defining government, police forces became important public institutions in the nineteenth century. Historically, these police forces differed greatly from our modern understanding of the institution. Police forces in Salvador and New Orleans did not investigate crimes as part of judicial proceedings. Police forces had two main responsibilities: to arrest individuals in the commission of crimes and to reinforce executive and judicial officials. By the nineteenth century, police forces also became a preventative organization. Rather than responding to the orders of government administrators and private citizens, the police also sought to prevent and detect crime. ${ }^{5}$

As legislators and the police transformed in the nineteenth century, so too did official conceptions of order and crime. Government officials felt that the well-being of a society depended upon legislation and policing of its security, economy, space, morals, and health. Governments had traditionally protected communities from crimes with individual victims: violent crimes — such as assault, murder, rebellion, robbery (presumably with force), and stabbings - and property crimes, including theft, trespassing, and using false monies. In the nineteenth century, legislators and the police began to emphasize a new sort of crime: crimes against public order. Public order crimes were ones that supposedly interfered with the operations, customs, or values of a society. Officials held that when an individual gambled, disturbed the peace, weighed goods

5. Richard C. Wade, Slavery in the Cities: The South 1820 - 1860 (New York, NY: Oxford University Press, 1964), 80 - 111; Aufderheide, "Order and Violence"; Holloway, Policing Rio de Janeiro; Dennis Charles Rousey, Policing the Southern City: New Orleans 1805 - 1889 (Baton Rouge, LA: Louisiana State University Press, 1997); Brown, "On the Vanguard of Civilization"”; Bryan Wagner, Disturbing the Peace: Black Culture and the Police Power After Slavery (Cambridge, MA: Harvard University Press, 2009), 58 - 65. 
improperly, or gathered illegally, he or she interfered with the orderly and efficient operation of a society. Cities were marked by the invention and policing of many new public order crimes in the era. ${ }^{6}$

In New Orleans and Salvador, slavery played an integral role in official conceptions of order and its policing. Slaves who lived, worked, and played within cities had always had unique opportunities afforded to them: they spent much of their daily life away from their masters' property; they occasionally used the cityscape or their occupations to run away, drink, and celebrate; and they lived in close proximity to free people of color. However, the ways that authorities legislated and policed enslaved people changed over time. In the eighteenth century, local government officials had a narrow mandate for policing slaves. Slave patrols, militias, and capitães do mato (slave catcher) were to seek out runaways and rebellious slaves. These types slave disorders were the very basis of public order crimes. By the nineteenth century, a more expansive mandate emerged. Police forces arrested not only runaways and rebels, but also enslaved people who committed minor infractions that impeded public economy, public space, public morals, and public health. In efforts to protect public welfare, local authorities began to regulate and police slavery through attention to far less serious crimes than rebellion.

The early nineteenth-century evolution in legislative and police efforts to control enslaved people can be divided into distinct phases or periods. In the earliest period,

6. Helen Boritch and John Hagan, "Crime and the Changing Forms of Class Control: Policing Public Order in 'Toronto the Good'," Social Forces 66, no. 2 (December 1987): 307 - 55; Algranti, "Slave Crimes," 31. 
officials focused tightly on the prevention of larger public safety concerns within the slave community. Legislators and the police attempted to prevent the conditions that enabled enslaved people to run away or violently resist. In the second period, officials regulated slaves and the individuals whom they came in contact with. Partly as a response to slave rebellions in and around each city, officials developed comprehensive systems for regulating slavery that rested upon surveillance not only of slaves, but also of their masters and free people of color. Legislators and the police also established and enforced new laws to prevent resistance and rebellion. In the final phase, officials continued to survey those around the slave community and created a more comprehensive set of laws focused on slaves and their relationship to public safety, economy, space, and morals. The argument, of course, is not that the legislation of slavery was unique to the nineteenth century. Instead, my dissertation holds that the creation of preventative police forces allowed legislators to create expansive regulations for slavery in New Orleans and Salvador by the second half of the nineteenth century.

Yet, my dissertation is not only an institutional study of legislators and the police. Legislative and police records provide an avenue to examine and understand the actions of those in society who were not able to write their stories. As the police often encountered and arrested individuals on the fringes of society, including slaves, they created a written account of such people's actions. To be sure, these records only highlight those few individuals who came in contact with police forces in the official government records. My dissertation does not lay claim to being a comprehensive study of crime and criminality. By the same token, arrest records only represent a small sample 
of the actions of government institutions. ${ }^{7}$ However, the patterns that emerged from these sources illuminate important aspects of law, law enforcement, and the individuals arrested. When policing is compared with written statutes, a clear picture emerges of the practices, theories, and transformations of public order in the early nineteenth century.

\section{Contribution to the Historiography of Brazil and the United States}

Since the appearance of Frank Tannenbaum's (1946) Slave and Citizen: The Negro in the Americas, scholars writing on race, slavery, and formal government institutions - the laws, courts, militaries, police, and legislative bodies - in the Americas have approached their projects in similar ways. Implicit in their work is an assertion that these institutions were a determining factor in the development of slave societies. With an institutional focus, scholars have insisted on differences between the cities, states, and countries that sprang from Dutch, English, French, Portuguese, and Spanish colonial roots. ${ }^{8}$ Using the institution of the police, my dissertation serves as a counterpoint to this vein of historiography. It holds that similar official concepts of order emerged in regions with different legal histories. The response of legislators and the police to the slave population in New Orleans and Salvador was more alike than it was different.

7. Holloway, Policing Rio de Janeiro, 10.

8. Frank Tannenbaum, Slave and Citizen: The Negro in the Americas (Boston, MA: Beacon Press, 1946); Alejandro De La Fuente, "Slave Law and Claims-Making in Cuba: The Tannenbaum Debate Revisited," Law and History Review 22, no. 2 (Summer 2004): 339 - 69; Ariela Gross and Alejandro De la Feunte, "Slaves, Free Blacks, and Race in the Legal Regimes of Cuba, Louisiana, and Virginia: A Comparison," North Carolina Law Review 91, no. 5 (2013): 1699 - 756; Robert J. Cottrol, The Long, Lingering Shadow: Slavery, Race, and Law in the American Hemisphere (Athens, GA: University of Georgia Press, 2013). 
My dissertation also contributes to the literature that examines slavery in New Orleans and Salvador. Within the historical scholarship on New Orleans, Louisiana, and the United States, scholars have acknowledged the importance of many different institutions, but they have often held that legislative bodies and courts were most instrumental in the ordering of race relations. In addition, they have understood New Orleans as an epicenter of a transition from French to Spanish to American slave law. Thus, they have compared the French Code Noir (1724) and the Spanish Siete Partidas to the 1821 and 1845 Louisiana Constitutions in order to tell the story of the transformation of Louisiana's slave law. These legal codes were integral to Louisiana and its slave system. However, this approach tends to obscure the actions of legislators, the police, and enslaved people in the development of official conceptions of orderly slavery in New Orleans. ${ }^{9}$ Similarly, other scholars have examined the police in New Orleans, but the actions of enslaved people rarely affect the storyline of their institutional histories. ${ }^{10}$ By

9. Judith Kelleher Schafer, Slavery, The Civil Law, and the Supreme Court of Louisiana (Baton Rouge, LA: Louisiana State University Press, 1994); Kimberly S Hanger, Bounded Lives, Free Black Society in Colonial New Orleans, 1769 - 1803 (Durham, NC: Duke University Press, 1997); Gilbert C Din, Spaniards, Planters, and Slaves: The Spanish Regulation of Slavery in Louisiana, 1763 - 1803 (College Station, TX: Texas A \& M University Press, 1999); Thomas N. Ingersoll, Mammon and Manon in Early New Orleans: The First Slave Society in the Deep South, 1718 - 1819 (Knoxville, TN: University of Tennessee Press, 1999); Judith Kelleher Schafer, Becoming Free, Remaining Free: Manumission and Enslavement in New Orleans, 1846 - 1862 (Baton Rouge, LA: Louisiana State University Press, 2003); Jennifer M. Spear, Race, Sex, and Social Order in Early New Orleans (Baltimore, MD: The Johns Hopkins University Press, 2007); Rebecca J Scott, "Slavery and the Law in Atlantic Perspective: Jurisdiction, Jurisprudence, and Justice," Law and History Review 29, no. 4 (November 2011): 915 24.

10. James F. Richardson, Urban Police in the United States (London, UK, 1974); Derek Kerr, Petty Felony, Slave Defiance, and Frontier Villainy: Crime and Criminal 
using the arrest records of the period, a rarely used source, my dissertation looks beyond court records, legislation, newspapers, and personal accounts for a better understanding of the day-to-day practices and theories that guided the policing of slavery. My dissertation holds that the growth of the city and the actions of enslaved people influenced both constructions of public order and the development of the New Orleans City Council and the City Guard.

Within the scholarship on Salvador, Bahia, and Brazil, meanwhile, my dissertation's temporal frame represents an important contribution. My dissertation examines the long-term changes taking place in Salvador by studying the early imperial era, 1824 - 1850. In the historiography of Salvador, scholars have analyzed the importance of the legal and institutional responses to the actions of enslaved and free people of color. The historiographic field has mainly revolved around Brazilian independence (1821 - 1824) and the Revolta dos Malês, a slave revolt attributed to the growing population of Muslim enslaved people within Salvador in 1835. Scholars have suggested that these events largely determined the subsequent character of Salvador's slave society. While these events did change local, regional, and national legislation, my dissertation holds that the policing of slavery developed incrementally. ${ }^{11}$ Before these

Justice in Spanish Louisiana, 1770 - 1803 (New York, NY: Garland Publishers, 1993); Rousey, Policing the Southern City.

11. João José Reis, Slave Rebellion in Brazil: The Muslim Uprising of 1835 in Bahia, Arthur Brakel, Arthur Brakel (Baltimore, MD: John Hopkins University Press, 1993); Graden, "An Act 'Even of Public Security"; Dale Torston Graden, “"The City Has Too Many Slaves Joined Together': The Abolitionist Crisis in Salvador, Bahia, Brazil, 1848 - 1856," in The African Diaspora, Alusine Jallah and Stephen E. Maizlish (College Station, 1996), 134 - 52; Brown, “'On the Vanguard of Civilization"”; Brown, 
events, provincial and municipal officials had already created legislation and institutions to police slavery. When independence and the Revolta dos Malês occurred, therefore, they only served to accelerate an existing pattern of change. Throughout, government officials actively shaped the laws and institutions guiding slavery in the name of public welfare.

The combination of New Orleans and Salvador in my dissertation serves as a means to contrast the theories and practices that guided the policing of slavery in the early nineteenth century. Aside from the obvious differences of locality and thus, national political events and chronologies, the legislation and police practices undertaken in the name of public welfare made Salvador and New Orleans more alike than different. The growth of urban Atlantic slavery in the nineteenth century resulted in comprehensive efforts to police slaves as part of public order. In response to enslaved people's actions, state and local authorities passed laws that limited enslaved people's lives. Legislation also created robust police institutions that became a preventative force. In the process, a new understanding emerged in Atlantic slaveholding cities among officials and elites: public welfare meant policing slavery as a whole and not just individual runaways and rebels.

Several key differences persisted between New Orleans and Salvador, however. First, different types of governmental agencies were at play in these cities since New

\footnotetext{
“"A Black Mark on Our Legislation"”; Mieko Nishida, Slavery and Identity: Ethnicity, Gender, and Race in Salvador, Brazil, 1808 - 1888 (Bloomington, IN: Indiana University Press, 2003); Dale Torston Graden, From Slavery to Freedom in Brazil: Bahia, 1835 1900 (Albuquerque, NM: University of New Mexico Press, 2006).
} 
Orleans and Salvador were state and provincial capitals, respectively. Territorial, state, and provincial legislators all established laws directed at the city. In New Orleans, state and territorial authorities largely left the New Orleans City Council to its own devices. However, Salvador's câmara (city council) worked alongside the Bahian Legislative Assembly and the Bahian provincial administrators to make legal codes specifically for Salvador.

Second, the records of the police represented two different approaches to policing the urban enslaved population. The arrest records and patterns in each city varied greatly in each city. In New Orleans, the City Guard initially arrested slaves at rates higher than their percentage of the population. Arrest rates slowly began to reflect the proportion of enslaved people by the 1820s and 1830s. In Salvador, officials did not always indicate whether individuals were slaves. Ethnicity was more commonly used than legal status in official police records. Nonetheless, the records of Salvador suggest an opposite trend. The arrest rates of slaves were lower than their representative percentage of population initially. By the 1840 s, police officials arrested slaves at a more proportional rate than in earlier eras.

Third, the police records illustrated different forms of engagement with slaveowners in New Orleans and Salvador. Masters were very difficult to trace within official police records in both New Orleans and Salvador. In all of the records that my dissertation surveyed, there was not a single arrest of a master for crimes against slaves or against public order. This suggested that laws that applying to masters more likely clarified liability than served as mandates for the police to arrest and punish masters. Nonetheless, the report of the Captain of the Guards in New Orleans contained 
information pertaining to masters. These records showed that masters increasingly had their slaves arrested. Whether or not masters did so to avoid to persecution was impossible to ascertain; however, by submitting their slaves to city authorities, masters tacitly justified or legitimated police authority.

\section{Chapters}

My dissertation focuses on the slow transformation of policing in New Orleans and Salvador in six paired chapters, organized into three parts. Each part examines New Orleans and Salvador in chronological periods when similar events occurred. The parts do not examine the same years in each city, but rather highlight similar developments in the policing of slavery, which took place at slightly different times in the two cities.

Part I examines the years 1804-1811 in New Orleans and 1823-1835 in Salvador, in order to focus on the demographic, economic, and political growth accompanying key political transitions - the Louisiana Purchase and the subsequent transition to American rule (1804) and Brazilian Independence (1821-1824) - and their influence on the policing of local slave laws. The first chapter, "New Orleans: 1804-1811," traces policing and slavery in an era of drastic change as a result of demographic, economic, and political currents. In New Orleans, the Louisiana Purchase let loose westward expansion in the United States. Westward expansion drove economic and demographic growth in New Orleans. American settlers came into conflict with a group of established inhabitants tracing their roots back to the French and Spanish colonial eras, called Creoles. Enslaved people capitalized upon the growth and the political instability. As they lived, worked, and recreated in the city, they sometimes broke official conceptions 
of order. In response, territorial and municipal officials largely focused on policing enslaved people who ran away or rebelled.

Chapter 2, "Salvador: 1823 - 1835," follows the policing of slavery in Salvador from Brazilian independence (1821 - 1824) to the Revolta dos Malês (1835). Brazilian independence redefined the political landscape and placed power within the hands of provincial and municipal officials. Independence also facilitated particular commercial and political events within Salvador. Trade in sugar and tobacco created an important demographic and economic impetus. In the years that followed, Salvador's population increased. Enslaved people were an essential part of these events. Their labor was crucial to the development of the city. However, their actions also sometimes threatened official conceptions of public order. Municipal legislators and provincial police forces focused their efforts on policing runaway slaves.

Part II analyzes the years 1811-1815 in New Orleans and 1835-1838 in Salvador. While demographic, economic, and political developments continued within each city, local slave rebellions prompted distinct responses from regional and municipal officials. Government authorities established new conceptions of orderly slave society. Legislators and the police took a heavy-handed approach to controlling slavery through a focus on the slave community and the individuals related to this community.

Chapter 3, "New Orleans: 1811-1815," examines the period of time between the German Coast Rebellion (1811) and the Battle of New Orleans (January 1815). The period was one of great instability, in which enslaved people capitalized upon the volatile circumstances to rebel and run away. Instability accelerated the development of municipal ordinances and changed the mandates of the police. In the period, New 
Orleans City Council passed new slave laws and increased the authority of the New Orleans City Guard. After the threat of rebellion and war subsided, government officials in New Orleans did not roll back these changes but continued to regulate slavery through policing enslaved people and related individuals.

Chapter 4, "Salvador: 1835 - 1838," follows changes in Salvador that resulted in the aftermath of the Revolta dos Malês. The rebellion and its impact highlighted how contemporaries understood social disorder. Bahian officials sought to deal with the possibility for slave resistance through a number of police reforms and increasingly restrictive laws and ordinances on enslaved people and their masters. In response to the Revolta dos Malês, provincial officials created new laws and police institutions to police the slave population and the individuals who interacted with it.

Part III investigates the years 1815-1835 in New Orleans and 1838-1850 in Salvador. After restoring stability in each city, officials continued to surveil and police enslaved people and others in an attempt to order slavery. Legislators and the police remained significant components of policing slavery. Collectively, these chapters tell the story of the establishment of the broad police authority that marked modern cities and would persist even after governments abolished slavery.

The fifth chapter, "New Orleans: 1815 - 1835," traces the institutional changes in New Orleans after the instability of the early-1810s. Even as the threat of rebellion subsided, officials continued to pass ordinances that regulated enslaved people and their masters for the sake of public order. The New Orleans City Council created new legislation that made enslaved people easier to surveil and police. The City Council also expanded the mandate of the New Orleans City Guard. Although the City Guard began 
to arrest other individuals at higher rates than before, policing slavery remained an important part of official conceptions and practices of order. The City Council and City Guard endured as important components of New Orleans in the years that followed.

"Salvador: 1838 - 1850" follows the changes that occurred in Salvador after 1838. The Bahian Legislative Assembly, provincial authorities, and Salvador's câmara drove official responses to enslaved people in the era. At the same time, provincial legislators established and supported new police forces. For decades to follow, these institutions persisted as a part of slavery in Salvador.

Altogether, these chapters trace an important period of transition within urban policing, when governmental oversight emerged as a part of everyday life in cities. Policing and public order grew in relation to enslaved people in slaveholding cities. Legislators and the police established and policed new slave laws that responded to the actions of enslaved people and urban environment. At the same time, the individuals who interacted with slaves everyday became subject to increased policing.

\section{Notes on Terminology}

In the following pages I have made a conscious effort to let the historical records speak for themselves. As part of the enterprise, I purposefully use the terminology of the historical period and region. In some small way, I hope that the will allow readers to better understand how contemporaries discussed issues like race, ethnicity, and skin color and thus the differences between constructions of such discourses in Brazil and the United States.

At any given time, enslaved and free people of color could be identified by a variety of traits. Contemporaries most commonly used ethnicity or skin color to identify 
such people. Within judicial documents, court officials often identified enslaved people by their place of origin or ethnic identity. However, police records often concerned themselves with observable remarks on skin color and status. Within the New Orleans Reports of the Captains of the Guards, the captain identified people of color with the terms "black," "negro," a person of solely black descent, "griffe," a person one-quarter white by descent, "mulatto," a person equally white and black by descent, and "quadroon," a person one-quarter black by descent. Contemporaries used these definitions in assumptions of ancestry to indicate skin color. These descriptors, however, were also used to denote status. The three most common forms were the annotation "H[omme].D[e].C[oleur].L[ibre]," free man of color; "negre de," meaning the negro belonging to someone; and "S[e].D[isant].L[ibre]," one who states he or she is free.

Skin color was a common identifier, but distinctions between foreign-born and Brazilian-born persons were also made within the Parte Geral of Salvador. Therefore, observations within the records often reported "preto," a person of solely black descent, "cabra," a person of a color between black and brown, "mulato," a person equally white and black by descent, or "pardo," a light-skinned person of black and white ancestry. Yet, officials sometimes indicated whether the person of color was an "African $(\mathrm{o} / \mathrm{a})$ " or "Crioul(o/a)", denoting whether African or Brazilian-born. ${ }^{12}$

12. Carl N. Degler, Neither Black Nor White: Slavery and Race Relations in Brazil and the United States (New York, NY: Macmillan, 1971), 102 - 04; Africa and the Americas: Interconnections During the Slave Trade, ed. José C. Curto and Reneé Soulodre-La France (Trenton, NJ: Africa World Press, 2005), 279 - 85. 
In the work, I have also chosen to relate prices as they were written. The description should allow for a greater command of the similarities and differences between Brazil and the United States. In New Orleans, the word escalin (a historic unit of currency in the Netherlands) remained a vernacular term for a dollar. Until the midtwentieth century, Brazilian currency was the mil-réis. One thousand réis comprised the mil-réis. In written form, one mil-réis was written as $1 \$ 000$. The relationship of the milréis to the U.S. dollar fluctuated throughout the nineteenth century. (See Table 1) Table 1: The average exchange rate of milréis in U.S. cents from 1830 to 1890

\begin{tabular}{|c|c|}
\hline Year & $\begin{array}{c}\text { Average } \\
\text { Value of one } \\
\text { mil-réis in } \\
\text { U.S. cents }\end{array}$ \\
\hline 1830 & $\$ 0.46$ \\
\hline 1840 & $\$ 0.63$ \\
\hline 1850 & $\$ 0.58$ \\
\hline 1860 & $\$ 0.52$ \\
\hline 1870 & $\$ 0.45$ \\
\hline 1880 & $\$ 0.45$ \\
\hline 1890 & $\$ 0.46$ \\
\hline
\end{tabular}

Source: Julian Smith Duncan, Public and Private Operation of Railways in Brazil (New York City, NY, 1932), 183, quoted in Thomas H. Holloway, Policing Rio de Janeiro: Repression and Resistance in a 19th-Century City (Stanford, CA: Stanford University Press, 1993), xvi.

A series of yearly comparisons that follows suggests that rough approximation of the era suggested that one U.S. dollar equated two Brazilian mil-réis. ${ }^{13}$

13. Julian Smith Duncan, Public and Private Operation of Railways in Brazil (New York City, NY, 1932), 183; Holloway, Policing Rio de Janeiro, xvi. 


\section{PART I}

The Development of Public Police Forces and the Prevention of Rebellions and Running

Away

The first period-1804 to 1811 in New Orleans and 1824 to 1835 in Salvadorwas defined by preliminary attempts for the municipalities to structure themselves and their policing within larger important political changes. The Louisiana Purchase and subsequent transition to American control (1803 - 1804) and Brazilian independence (1821 - 1824) facilitated demographic, economic, and political changes in each city. As enslaved people lived, worked, and recreated in these cities, they responded to the development of the city in ways that sometimes challenged public order. Territorial and municipal bureaucrats created new legislation. Police also became central to public order. 


\section{CHAPTER 1}

New Orleans

$1804-1811$

\section{Introduction}

As rumors spread that French rule would be restored in Louisiana when Napoleon advanced throughout Europe, Jacques-François (James) Pitot— the future mayor of New Orleans and Judge of Orleans Parish Court — wrote a manuscript highlighting the great potential of the Louisiana colony. ${ }^{1}$ Pitot created the guidebook for officials and merchants detailing the government, finance, religion, commerce, and agriculture within the colony. While generally positive about Louisiana's prospects, the author used the platform to criticize the Spanish colonial government and its maintenance of order. In particular, Pitot suggested that the governor's heavy-handed control of matters relating to the police, courts, and military fostered disorder. Authoritarianism paralyzed an extensive system of policing, comprised of runaway slave patrols, serenos (night watchmen), alguacil mayors (sheriffs), tenientes (deputies), and syndics (justices of the peace) and facilitated confusion throughout the region. ${ }^{2}$ Authoritarianism also had disastrous effects on New Orleans.

1. Spain took possession of Louisiana from France during the Seven Years War (1754/6 - 1763). France had a presence in the region since the seventeenth century and established New Orleans as the government seat of the colony in 1722. France would remain in possession of Louisiana until the Treaty of Fontainebleu, a secret agreement that gave Spain possession of the region in the final years of the Seven Years War. Pitot, Observations of the Colony of Louisiana from 1769 to 1802, xi - xxiii.

2. In Spanish New Orleans several groups performed policing functions: Serenos (nightwatchmen); alguacil mayor (sheriff); tenientes (deputies); and syndics (justice of 
Described as disorderly since the eighteenth century, New Orleans continued to be characterized as a haven for runaway slaves, gambling dens, illicit taverns, fenced goods, and illegal balls in the nineteenth century. ${ }^{3}$ Pitot proposed that New Orleans would benefit from municipal institutions that oversaw the "drainage of the city, street cleaning,...patrols, surveillance of gambling houses, inspection of dance halls and theatres, and immediate imprisonment of vagrants and fugitive slaves." These institutions would improve conditions by maintaining the city's "security, good order, and healthfulness." ${ }^{\prime 4}$ Although the Louisiana Purchase would dash the hopes of French institutional reform, Pitot's refined understanding of the relationship between "good order," authorities, and institutions mirrored the reforms that Americans initiated in the years that followed.

peaces. Patrols or serenos (nightwatchmen) illuminated lamps, arrested individuals in the commission of crimes, and alerted the city in the case of fire. The alguacil mayor and his tenientes supervised the prison, executed criminals, and apprehended criminals with warrants. Syndics - a position initially brought to Louisiana under French rule- judged minor criminal activity, reported strangers, enforced livestock and boundary regulations, regulated slavery, and directed repairs to levees, bridges, and roads. Each of these institutions had a stake in controlling order in the cities and the countryside throughout Louisiana. John Edwards Harkins, "The Neglected Phase of Louisiana's Colonial History: The New Orleans Cabildo, 1769 - 1803," Phd Dissertation (Memphis, TN: Memphis State University, 1976), 112; Derek Kerr, Petty Felony, Slave Defiance, and Frontier Villainy: Crime and Criminal Justice in Spanish Louisiana, 1770 - 1803 (New York, NY: Garland Publishers, 1993), 177 - 86.

3. Pitot, Observations of the Colony of Louisiana from 1769 to 1802, 29; Jack D. L Holmes, "The Abortive Slave Revolt at Pointe Coupée, Louisiana, 1795," Louisiana History 11, no. 4 (1970): 341 - 62; Kerr, Petty Felony, Slave Defiance, and Frontier Villainy, 198 - 203; Shannon Lee Dawdy, Building the Devil's Empire: French Colonial New Orleans (Chicago, IL: The University of Chicago Press, 2008).

4. Pitot, Observations of the Colony of Louisiana from 1769 to 1802, 27. 
This chapter traces policing and slavery in New Orleans from 1804 to 1811 , when the police emerged as an important component of government authority in the city and its slavery. At the turn of the century, New Orleans entered an era of significant and interrelated demographic, economic, and political change. As the United States expanded westward, expansion created new opportunities within New Orleans. Trade in sugar and cotton increased in the Mississippi River Valley. Commerce supported New Orleans' economy and enticed settlers from the United States, Saint-Domingue, and Europe to settle the city. These individuals also brought slaves to the city. The New Orleans City Council and the City Guard responded to the slave population, and more specifically the enslaved people who went against official conceptions of public welfare by running away and rebelling. In the 1810s, New Orleans' criminal justice system was put to the test. Slave rebellion and warfare mandated changes in official constructions of order and its policing.

Between 1804 and 1811, officials in New Orleans sought to order the city through legislative and police reforms. Political rivalry between French, Spanish, and American interests also influenced these reforms. After the Louisiana Purchase (1804), the United States government charged legislators and officials with implementing American laws, institutions, and practices while accommodating a powerful group of inhabitants tracing their roots back to the French and Spanish colonial periods, called Creoles. President Thomas Jefferson appointed the Virginia-born William Charles Cole (W.C.C) Claiborne as governor of the Orleans Territory to oversee the initial transfer of power. Claiborne established many of the early reforms during the transition from Spanish to French to American rule. However, New Orleanians quickly took over their own governance. 
Creoles, who made up a large portion of New Orleans, dominated the City Council and the Orleans Legislature. In the City Council, Creoles established their own laws and institutions in New Orleans. Claiborne and the Creoles emphasized different strategies for governance and power, yet their conceptions of policing slavery largely remained the same. ${ }^{5}$

Slavery was a main source of disorder in the years after the Louisiana Purchase. First, a number of slaves took advantage of the unsettled borders with Spanish Texas to escape. Second, traders and masters brought a number of enslaved people from other parts of the United States and Saint Domingue to work in the fields and cities of Louisiana. These trends prompted a government response. Claiborne and the New Orleans City Council responded to the actions of the slave owners and enslaved people through regulations on runaway and rebellious slaves. ${ }^{6}$

Contemporary constructions of good order in the era reflected a mix of French, Spanish, and American theories. The New Orleans City Council promoted order through comprehensive ordinances, regulating how enslaved people lived, worked, and played. These ordinances created curfews, banned offensive weapons, prohibited assemblies, established standards for living and hiring out, and limited the ability of slaves to work on ships. However, the City Council continued to search for the proper police forces to

5. Dennis Charles Rousey, Policing the Southern City: New Orleans 1805 - 1889 (Baton Rouge, LA: Louisiana State University Press, 1997), 6 - 23; Peter J. Kastor, The Nation's Crucible: The Louisiana Purchase and the Creation of America (New Haven, CT: Yale University Press, 2004), 63 - 107. 107.

6. Rousey, Policing the Southern City, 6 - 23; Kastor, The Nation's Crucible, 63 - 
enforce such legislation. They experimented with several different police groups:

informal watches (1804), gendarmerie (1805 - 1806), the City Guard (1806 - 1808; 1809

- 1836), reinforced constables (1808), and lamplighter-watchmen (1808 - 1809). Over

time, the City Guard proved to be the most effective police force and operated as New Orleans' sole police force for the next several decades. ${ }^{7}$

The chapter argues that municipal and police officials began to transform the relationships between authorities, enslaved people, and their masters in New Orleans between 1804 and 1811. During this period, ordinances based upon Spanish and French legal code gave way to new laws and policing practices that corresponded to the growth of the city. The chapter thus adds another dimension to what we already know about slavery in New Orleans by pointing to the importance of laws and their enforcement. Many historians have discussed the demographic, economic, legal, and political changes within New Orleans and their effects on the trajectory of slavery. Scholars have focused on the differences between French, Spanish, and American legal codes. Yet, these works have failed to properly understand the impact of the institutions charged with enforcing legislation. ${ }^{8}$ The chapter brings the City Council and City Guard into a discussion with

7. Rousey, Policing the Southern City, 14 - 19.

8. Hans W Baade, "The Law of Slavery in Spanish Luisiana 1769 - 1803," in Louisiana's Legal Heritage, Edward F. Hass (Pensacola, FL: Louisiana Historical Society, 1983), 45 - 86; Kerr, Petty Felony, Slave Defiance, and Frontier Villainy; Judith Kelleher Schafer, Slavery, The Civil Law, and the Supreme Court of Louisiana (Baton Rouge, LA: Louisiana State University Press, 1994); Rousey, Policing the Southern City; Gilbert C Din, Spaniards, Planters, and Slaves: The Spanish Regulation of Slavery in Louisiana, 1763 - 1803 (College Station, TX: Texas A \& M University Press, 1999); Thomas N. Ingersoll, Mammon and Manon in Early New Orleans: The First Slave Society in the Deep South, 1718 - 1819 (Knoxville, TN: University of Tennessee Press, 
the demographic, economic, legal, and political changes, so the practices and theories that guided formal local authority become the focus. Legal codes and arrest records indicate that enslaved people and slavery played a prominent role in official constructions of public order in New Orleans.

The chapter also holds that urban expansion affected slave laws and policing in the era. As the commercial and demographic changes within New Orleans created opportunities for enslaved people, local officials responded with new urban ordinances. Police forces interpreted and applied legislation to the slave community. Through these efforts, municipal institutions became important actors. Legislators and the police developed into interlocutors between enslaved people, their masters, and the public.

\section{New Orleans at the Time of the Louisiana Purchase}

On July 15, 1804, W.C.C. Claiborne, the newly appointed territorial governor of Louisiana, reported to Secretary of State James Madison an event that caused much "anxiety." Several citizens "hoisted the French flag and sung their favourite national songs" in commemoration of Bastille Day, a French national holiday celebrating the beginning of the French Revolution. The celebration of radical French political events in a city divided between English and French-speaking groups had serious implications. Claiborne was only able to decrease tensions after he told the Americans "that

1999); Judith Kelleher Schafer, Becoming Free, Remaining Free: Manumission and Enslavement in New Orleans, 1846 - 1862 (Baton Rouge, LA: Louisiana State University Press, 2003); Kastor, The Nation's Crucible; Jennifer M. Spear, Race, Sex, and Social Order in Early New Orleans (Baltimore, MD: The Johns Hopkins University Press, 2007); Rebecca J Scott, "Paper Thin: Freedom and Re-Enslavement in the Diaspora of the Haitian Revolution," Law and History Review 29, no. 4 (November 2011): 1061 - 88. 
indulgences of a similar kind were allowed to foreigners in the United States, and that Americans[,] when abroad[,] very frequently on the 4th. July[,] unfurled the Standard of their country and drank to her prosperity." ${ }^{\prime 9}$ While direct contestation subsided in the years that followed, New Orleans remained a divided city. Yet, social and political discord continued to shape New Orleans as it grew substantially in the years after the Louisiana Purchase.

The Louisiana Purchase created an important context for New Orleans and Louisiana. When President Thomas Jefferson purchased Louisiana for fifteen million dollars and appointed W.C.C. Claiborne its territorial governor, he initiated a period of change, where the United States expanded westward and New Orleans became the metropolis of the West. The city's docks filled with goods transported on the Mississippi River. The city's boundaries expanded as settlers moved to the region. Yet, Creoles retained a controlling stake in these developments and used them to challenge American officials as they came to the city. These events shaped government institutions, which would be responsible for creating order to control New Orleans' slave population. ${ }^{10}$

9. W.C.C. Claiborne, "James Madison From William C.C. Claiborne, 15 July 1804 (Abstract)," Source: The Papers of James Madison, Secretary of State Series, vol. 7, 2 April-31 August 1804, ed. David B. Mattern, J.C. A. Stagg, Ellen J. Barber, Anne Mandeville Colony, Angela Kreider, and Jeanne Kerr Cross. Charlottesville: University of Virginia Press, 2005, p. 457. (Founders Online, National Archives).

10. George Dargo, Jefferson's Louisiana: Politics and the Clash of Legal Traditions (Cambridge, MA: Harvard University Press, 1975), 1 - 40; Kastor, The Nation's Crucible, 55 - 110; Sean Wilentz, The Rise of American Democracy: Jefferson to Lincoln (New York, NY: W.W. Norton and Company, 2005), 108 - 13; Gordon S Wood, Empire of Liberty: A History of the Early Republic, 1789 - 1815 (New York, NY: Oxford University Press, 2009), 368 - 74. 
Prior to the Louisiana Purchase, New Orleans was the center of modest but thriving river commerce. Principally trading in "sugar, cotton, indigo, rice, furs and peltry, lumber, tar, pitch, lead, flour, horses and cattle," Spanish Louisiana conducted $\$ 2,153,000$ of exports through New Orleans between 1799 and 1802 . Income from trade made up the lion's share of the colony's revenue. Commerce increased as Louisiana's nascent sugar industry experienced a boom, when Saint-Domingue's sugar industry collapsed during the Haitian Revolution (1791 - 1804). Saint-Domingue was the world's major sugar producer prior to the Haitian Revolution; however, warfare crippled sugar production and left the world looking for other suppliers, like Louisiana and Bahia. Moreover, the westward expansion of the United States promised to bring new revenue to New Orleans. It was on the docks of New Orleans that Mississippi River canoes, barges, and floats mixed with ocean-going freighters. However, inhabitants of the city could hardly anticipate the stimulus that cotton and sugar would provide in the years that followed. ${ }^{11}$

As profits increasingly flowed through New Orleans, Americans, immigrants, and their slaves settled in the city. Official U.S. estimates suggests that the population of Orleans Parish increased by 8,945 inhabitants between 1803 and 1810 . The demographic influx indicated a little over two-fold growth in around seven years, as the population of

11. John Sibley, An Account of Louisiana Laid Before Congress by Direction of the President of the United States November 14, 1803 (Providence, RI: Heaton \& Williams, 1803), 65 - 66; Amos Stoddard, Sketches, Historical and Descriptive of Louisiana (Philadelphia, PA, 1812), 293 - 306. 
the city grew from 8,056 to 17,242 between 1803 and 1810. People capitalized upon the economic growth and moved to the city. ${ }^{12}$

The period also was marked by an in-fighting of citizens over the trajectory of the region. The political divisions between Americans and Creoles had repercussion on the demographic and economic growth of New Orleans. Creoles fought to retain the form and function of French and Spanish government, while American authorities sought to impose Anglo-American theories and practices. Clashes between these two groups over the judicial and legal trajectory of Louisiana took place both within the halls of the state and the municipal legislature. Americans won out initially; however, Creoles assumed power over the New Orleans City Council when it was created in 1805. Through the City Council, Creoles left their mark on New Orleans. ${ }^{13}$

The city's planning stood as an important example of the division between Creoles and American settlers. While the Vieux Carré (the part of the city that is presently referred to as the French Quarter) was once the entirety of the municipality, the city expanded beyond its traditional boundaries after the Louisiana Purchase. Creoles chiefly inhabited in the Vieux Carré. Americans settlers, Haitian emigrés, and their

12. Sibley, An Account of Louisiana, 46 - 48; U.S. Census, Third Decennial Census (Washington, D.C.: U.S. Government Printing Office, 1811), 82.

13. George Dargo, Jefferson's Louisiana: Politics and the Clash of Legal Traditions (Cambridge, MA: Harvard University Press, 1975); Thomas N. Ingersoll, Mammon and Manon in Early New Orleans: The First Slave Society in the Deep South, 1718 - 1819 (Knoxville, TN: University of Tennessee Press, 1999), 244 -80; Jennifer M. Spear, Race, Sex, and Social Order in Early New Orleans (Baltimore, MD: The Johns Hopkins University Press, 2007), 179 - 214; Rebecca J Scott, "Paper Thin: Freedom and Re-Enslavement in the Diaspora of the Haitian Revolution," Law and History Review 29, no. 4 (November 2011): 1061 - 88. 
slaves arrived in other parts of the city. These immigrants settled in the Faubourg Marigny, Faubourg Tremé, and Faubourg Saint Marie, the districts to the northeast, northwest, and southwest of the Vieux Carré, respectively. In the years that followed, a rivalry developed between the neighborhoods of Faubourg Saint Marie-the American business district—and the Vieux Carré.$^{14}$

Collectively, the commercial, economic, and demographic growth presented a challenge to officials within New Orleans. As commodities, monies, and people came to the city, authorities struggled with one another. Infighting created two distinct government powers that influenced official responses to the city's slavery and the enslaved people who threatened official conceptions of public welfare by running away and rebelling.

\section{Slaves}

On November 8, 1804, W.C.C. Claiborne issued a circular in New Orleans. As residents reported slaves escaping from the city and other areas for "Spanish Dominions" and "freedom," Claiborne alerted readers to the "spirit of great insubordination among the negroes [that] has been manifested." At the same time, he quieted fears by suggesting police vigilance and oversight. The governor finished the circular by presenting the maxim, "the best way to prevent mischief, is to be prepared to meet it." While the circular suggested a swift response, it also indicated that the actions of enslaved people affected official conceptions of order. Enslaved people in New Orleans were an essential

14. Nathalie Dessens, Creole City: A Chronicle of Early American New Orleans (Gainesville, FL: University of Florida Press, 2015), 170 - 74. 
part of the growth of the city. Slaves also reacted to opportunities around them. In the process, New Orleans' slave population became an important focus for local officials. ${ }^{15}$

A random sampling of Orleans Parish inventories indicated that enslaved people performed a variety of occupations within the city. These sources are a font of information for historians. Inventories were created for tax purposes and contained the estimated value of an individual's property. As property, enslaved people made up a significant proportion of some inventories, in that $49 \%$ of all inventories contained at least one record of a slave. These sources, therefore, contained valuable descriptors of enslaved people and the things that determined their worth, like their age, occupation, and skin color. ${ }^{16}$ In a way, these inventories became a means to account for the slave population. Authorities also used these documents to trace the transaction of property after an individual's death. For historians, inventories provide a way to understand which types of labor were most common. While enslaved people most frequently labored as domestics and agricultural workers, they also toiled as the transporters, tradespersons, and market sellers in New Orleans (See Table 2). ${ }^{17}$

15. W.C.C. Claiborne, "Circular. New-Orleans," Early American Imprints Series 2, no. no. 6965 (8 November 1804), America's Historical Imprints.

16. Edward E. Baptist, “'Cuffy,' 'Fancy Maids,' and 'One-Eyed Men': Rape, Commodification, and the Domestic Slave Trade in the United States," The American Historical Review 106, no. 5 (December 2001), 1633 - 1639; Walter Johnson, Soul by Soul: Life Inside the Antebellum Slave Market (Cambridge, MA: Harvard University Press, 1999), 1 - 77.

17. The dissertation uses a random sampling of the Orleans Parish Inventories between 1803 and 1840. The sample is compiled from 295 of the 3,329 total inventories. Amongst these inventories, heads of households collectively owned 766 slaves. Amongst the 766 slaves, 337 slaves had one or multiple recorded jobs. Collectively these 337 
Table 2: Occupations of Slaves within New Orleans' Inventories, between 1803 and 1840

\begin{tabular}{|c|c|c|c|}
\hline Occupation Groups & Occupations & Number & $\begin{array}{l}\text { Percentage } \\
\text { of Enslaved } \\
\text { People } \\
\text { working in } \\
\text { these } \\
\text { occupations }\end{array}$ \\
\hline Domestic & $\begin{array}{l}\text { Cooks, Washers, } \\
\text { Domestics, House } \\
\text { Servants, Ironers, } \\
\text { Nannies, and } \\
\text { Seamstresses. }\end{array}$ & 344 & $65 \%$ \\
\hline Agriculture & $\begin{array}{l}\text { Pickaxe Laborer, } \\
\text { Woodcutters, Laborers, } \\
\text { Fieldhands, and } \\
\text { Gardeners. }\end{array}$ & 83 & $16 \%$ \\
\hline Transportation & $\begin{array}{l}\text { Draymen, Coachmen, } \\
\text { Sailors, and Pilots. }\end{array}$ & 34 & $6 \%$ \\
\hline Tradepeople & $\begin{array}{l}\text { Bricklayers, Shoemakers, } \\
\text { Masons, Turners, } \\
\text { Plasterers, Joiners, } \\
\text { Sugarmakers, Saddlers, } \\
\text { Caulkers, Hatters, and } \\
\text { Chocolate Makers. }\end{array}$ & 48 & $9 \%$ \\
\hline Market Occupations & $\begin{array}{l}\text { Marketsellers, } \\
\text { Daylaborers, and } \\
\text { Milksellers. }\end{array}$ & 19 & $4 \%$ \\
\hline Total & & 528 & \\
\hline
\end{tabular}

Source: "Estate Inventories, 1803 - 1877," Orleans Parish Civil Court, Louisiana Division, New Orleans Public Library, New Orleans, Louisiana.

In these occupations, enslaved people were an important component of the development of the city. They worked in the houses of the city's inhabitants. They tended the

enslaved people had 528 occupations. "Estate Inventories, 1803 - 1877," Orleans Parish Civil Court, Louisiana Division (New Orleans Public Library). 
gardens, fields, and woods in and around New Orleans. They loaded ships and transported goods. They worked as skilled laborers, bricklayers, masons, carpenters, and rope makers. They sold goods in the city's markets. Enslaved people would remain a noteworthy part of New Orleans' workforce throughout the early nineteenth century (See Table 3.A. in Appendix for a complete list of occupations). ${ }^{18}$

As enslaved people worked within the city, they also lived and recreated there. Enslaved people met in New Orleans' famed Congo Square on Sundays, where they exchanged goods and attended religious ceremonies. They traded commodities in the city's markets. They sang songs and entertained other slaves. They attended public celebrations. Enslaved people mingled with free people of color and others in the city's taverns. While officials permitted these forms of entertainment initially, they would eventually restrict a number of these diversions by mid-century. ${ }^{19}$

An influx of enslaved people also made slavery more commonplace within New Orleans after the Louisiana Purchase. The slave population grew numerically while

18. "Estate Inventories, 1803 - 1877," Orleans Parish Civil Court, Louisiana Division (New Orleans Public Library).

19. "Connecticut; New Orleans; Prohibited," The Daily Picayune, 23 June 1838, 2; "Cabarets; Impunity; Police; Owner; Offence; Wise," The Daily Picayune, 15 June 1839, 2; Liliane Crété, Daily Life in Louisiana, 1815 - 1830, Patrick Gregory (Baton Rouge, LA: Louisiana State University Press, 1978); Gary A. Donaldson, "A Window on Slave Culture: Dances at Congo Square in New Orleans, 1800 - 1862," The Journal of Negro History 69, no. 2 (Spring 1984): 63 - 72; Jerah Johnson, "New Orlean's Congo Square: An Urban Setting for Early Afro-American Culture Formation," Louisiana History 32 (Spring 1991): 117 - 57; Andrew N. Wegmann, "No Ordinary, No Earthly Scene: Know-Nothingism and the Death of Congo Square," Social Identities: A Journal for the Study of Race, Nation, and Culture 35, no. 3 (Fall 2012): 34 - 59; Freddi Williams Evans, Congo Square: African Roots in New Orleans (Lafayette, LA: University of Louisiana at Lafayette Press, 2011). 
remaining roughly the same proportion of the city's inhabitants. Slaves made up slightly above one-third of the total population in the period. In 1803, enslaved persons accounted for 2,773 of the city's 8,056 inhabitants, or $34 \% .{ }^{20}$ The slave population grew to 5,961 of the city's 17,242 total inhabitants by 1810 , or $35 \%$. These statistics support perceptions of New Orleans having a large and vibrant slave community in the early nineteenth century. $^{21}$

Some enslaved people escaped New Orleans and the rest of the Orleans territory. A number of slaves capitalized upon the unsettled borders with Spanish Texas and reputed promises of freedom there. As a result, groups of enslaved people escaped westward. While there are no exact estimates of the number of runaways, it is important to note that runaways became a theme in a series of diplomatic correspondences between W.C.C. Claiborne and the governor of Texas, the Marques de Caso Calvo. ${ }^{22}$ Runaway slaves also fled to other places besides Texas, as enslaved people became maroons within New Orleans itself. The city and its substantial population of enslaved and free people of color provided an opportunity for slaves to hide and live. ${ }^{23}$ The multiple avenues for running away challenged territorial and municipal officials.

20. Sibley, An Account of Louiana, 46 - 48.

21. U.S. Census, Third Decennial Census (Washington, D.C.: U.S. Government Printing Office, 1811), 295.

22. Claiborne, "Circular"; W.C.C. Claiborne, "Claiborne to Casa Calvo," in The Letter Books of William C.C. Claiborne, 1801 - 1816, vol. 2, ed. Dunbar Rowland (Jackson, MS: Mississippi State Library and Archive, 1917), 382 - 83.

23. W.R.D. Earle, "Correspondence," W.R.D. Earle to James Mather, mayor of New Orleans, Charles F. Heartman Collection 1724 - 1897 (Suite 319, Building 38, Xavier University of Louisiana, 1 Drexel Drive, New Orleans, LA 70125, 1808); John 
Collectively, the growth of the city — and the roles of enslaved people in this growth — and runaway slaves became known as serious issues for government authorities in New Orleans. To put it in another way, officials in New Orleans interpreted runaway slaves as a major problem, yet, that problem was caused by slavery and by growth, neither of which the officials wanted to impede. So they turned instead to regulating of enslaved people to ensure the expansion of slave labor and masters' ability to bring in additional slaves. At the same time, it created new institutions that ensured control over the slave population, particularly the City Council and the City Guard. Therefore, the New Orleans City Council and the New Orleans City Guard emerged as guardians of public order, as described largely by the task of regulating enslaved people and their movements through the city.

\section{Police Organization}

On March 3, 1804, W.C.C. Claiborne responded to the anxieties of a "Committee of Respectable Citizens" in New Orleans. While serenos (nightwatchmen); alguacil mayors (sheriffs); tenientes (deputies); and syndics (justice of peaces) had sufficed for the Spanish and French, the Louisiana Purchase created uncertainty over what laws applied and who would enforce them. ${ }^{24}$ The "Committee of Respectable Citizens" appealed to the governor to make sure the American transition would occur smoothly. Claiborne responded by issuing the "Ordinance Regulating the City Police." As the ordinance

Hope Franklin and Loren Schweninger, Runaway Slaves: Rebels on the Plantation (New York City, NY: Oxford University Press, 1999), 126 - 30.

24. Kerr, Petty Felony, Slave Defiance, and Frontier Villainy, 30. 
created a police force to "repress disorders and maintain the quiet and Security of the City," it also made slaves an essential focus of policing. ${ }^{25}$

In the days before the New Orleans City Council formed and created a permanent police force, Claiborne's “Ordinance Regulating the City Police” performed an important function. The ordinance established a basic police force with conscripted free white male inhabitants. A resultant "Watch" operated at night and in small patrols. The watch served in a rotation under a police chief. These men patrolled their districts in rounds after a 9 p.m. curfew and apprehended "people who may be found transgressing regulations of the Police." The ordinance also established a mission for the watch. Claiborne entrusted the force "to apprehend and commit to prison" those who committed "crimes or breaches of the peace." The ordinance held that four major disturbances posed the deepest threat to order in New Orleans: slaves found out after a 9 p.m. curfew and without passes from their masters; all persons outside at "unseasonable hours" without good reason; people assembled at "Gambling houses, tipling Houses, and Houses of ill fame"; and "sailors and soldiers absent from their ship's after nine o'clock." From the finite mandate, the immediate concerns of New Orleans were laid bare. Order was something that needed policing; the watch and other police groups would be responsible

25. W.C.C. Claiborne, "Ordinance Regulating the City Police," in The Letter Books of William C.C. Claiborne, 1801 - 1816, vol. 2, ed. Dunbar Rowland (Jackson, MS: Mississippi State Library and Archive, 1917), 16 - 19. 
for public safety. Moreover, the city's enslaved population was a significant part of official constructions of order and, at the same time, made up a majority of arrests. ${ }^{26}$

In the months that followed, the New Orleans City Council passed new ordinances specifically aimed at the enslaved population. The City Council also experimented with a number of police forces. They responded to the instability associated with the demographic, economic, and political events of the time. They also reacted to the growth of New Orleans' slave population and the actions of enslaved people who threatened order.

As the New Orleans City Council formed in the winter months of 1805, it established a set of comprehensive ordinances to govern New Orleans. The council's first act was to draft and pass a series of regulations governing New Orleans. The one hundred and seven articles of the document covered everything from housing codes to dogs. Amongst these articles, the New Orleans City Council also found it essential to address slaves. In five articles of the law, the City Council borrowed heavily from the Code Noir and Bandos de Buen Gobierno. These provisions contained prohibitions on slaves carrying offensive weapons and restrictions against slave congregations (excluding Sundays). They also mandated slave curfews and established stipulations for where enslaved people, lived, they were required to live with their masters or with the persons

26. Claiborne, "Ordinance Regulating the City Police"; Rousey, Policing the Southern City, 2; Sally E. Hadden, Slave Patrols: Law and Violence in Virginia and the Carolinas (Cambridge, MA: Harvard University Press, 2003), 19 - 35. 
to whom they were rented out. These types of regulations came almost directly from French and Spanish legal precedents. ${ }^{27}$

Yet, other codes responded more directly to the growth of the city and a need to control those laboring in it. For example, these laws provided that enslaved and incarcerated individuals were to be used in the chain gang to clean streets and build municipal structures, including the batture (the earthen structure abutting the Mississippi River that controlled flooding). Officials used the chain gang not only to get labor out of those incarcerated but also to preserve the health of the city's inhabitants and protect the city. They also prohibited enslaved people from working on docked vessels unless permitted by their masters, in an attempt to prevent an avenue of escape. Regulations further restricted slaves from gambling. The City Council also created rules for hiring out enslaved people. These early ordinances responded to the presence of enslaved people within New Orleans' changing urban environment. They attempted to control the slave population by making it easier to surveil and police. Officials within the city now had justifications to stop and examine people of color, even when they were busy at work. These types of ordinances would be the first of many that placed restrictions on both the work and recreation of enslaved people in the name of public welfare. ${ }^{28}$

27. James Pitot, The Municipal Body. To All the Inhabitants of the City and Precincts of New-Orleans, Early American Imprints, Series 2, No. 9007 (New Orleans, LA, 1805); "Regulations of Police for the Town and Suburbs of New Orleans" in Louisiana's Code Noir in French, Historical Collections of Louisiana, 89 - 95; "Miró's Bando de Beun Gobierno," No. 1, Vol. 3, Records and Deliberations of the Cabildo, 1769 - 1803, Louisiana Division (New Orleans, LA: New Orleans Public Library, 1786).

28. New Orleans, Règlement General de Police: Pour la Ville et Banlieue de la Nouvelle-Orléans (New Orleans, LA: Jean Renard, 1805), 4 - 24, 28, 54. 
At the same time, New Orleans also experimented with a number of different police organizations. The first institution to replace Claiborne's watch was the gendarmerie (1804 - 1806). The gendarmerie was a mounted patrol that was subsidized through a one-dollar tax on each slave, payable by slaveholders. As with the watch, the gendarmerie acted as a nightly patrol. It also served as an auxiliary force during the day, if called upon by the local citizenry. Yet, the City Council had a hard time justifying the expenses of the mounted force and dissolved it in $1806 .{ }^{29}$ Following the experiment, the City Council established the New Orleans City Guard. The New Orleans City Guard (1806 - 1808) largely mirrored that of the gendarmerie. Although the City Guard was a foot patrol, it marched the street in rounds at night and served as a reserve force during the daytime. However, in 1808, the New Orleans City Council disbanded the City Guard, again citing the expense. ${ }^{30}$

A series of irregular police forces followed after the City Guard. The New Orleans City Council first created a group of reinforced constables. They worked with other bureaucrats in the city to enforce warrants, but they were not sufficient to maintain the security of the city at night. The City Council replaced the constables with a group of lamplighter-watchmen. These individuals were responsible for the upkeep of the city's street lighting system. They also reported any incidents occurring during their rounds. The tight relationship between the street-lighting system and policing remained a constant in New Orleans and Salvador throughout the early nineteenth century. Even

29. Rousey, Policing the Southern City, 16 - 17.

30. Rousey, Policing the Southern City, 17. 
after lamplighting responsibilities diverged from policing, police forces continually reported on the conditions of lamps in the city. This suggests the conviction of authorities that lamps were an important aspect of preserving public safety. By lighting the city at night, lamps made the urban landscape easier to surveil. Moreover, officials imagined lamps to be a deterrent to criminals, whose actions would be visible to police and inhabitants looking out into the city. Nonetheless, the New Orleans City Council also found these lamplighters inefficient and disbanded them in favor of a re-established City Guard in $1809 .^{31}$

The 1809 legislation that formed the New Orleans City Guard also defined the policing of New Orleans for the subsequent twenty-seven years. Like the gendarmerie and the earlier incarnation of the City Guard, the New Orleans City Guard was distinctly a military-styled police force, with a hierarchy like other armed forces. The basic unit of the grouping was the "round." Eight watchmen and a lieutenant comprised each round, and all rounds reported to a captain. These rounds organized at the central post at nightfall. The rounds then marched through their respective districts. The City Guard policed slaves and sailors found out in public at night. However, they could be called to respond to "all slaves making an uproar" and those "committing any offence against the

31. Rousey, Policing the Southern City, 17; "Report of the Captain of the Guards," Charles F. Heartman Collection 1724 - 1897 (Suite 319, Building 38, Xavier University of Louisiana, 1 Drexel Drive, New Orleans, LA 70125, 1809); "Report of the Captain of the Guards," Charles F. Heartman Collection 1724 - 1897 (Suite 319, Building 38, Xavier University of Louisiana, 1 Drexel Drive, New Orleans, LA 70125, 1814); "Report of the Captain of the Guards," Charles F. Heartman Collection 1724 - 1897 (Suite 319, Building 38, Xavier University of Louisiana, 1 Drexel Drive, New Orleans, LA 70125,1824$)$. 
public order, and also all slaves denounced as fugitives" at any time. ${ }^{32}$ In other words, enslaved people were imagined as pre-eminent in the New Orleans City Guard's mission. While the City Guard expanded as New Orleans grew in the early nineteenth century, the basic configuration remained until the New Orleans City Council passed legislation that broke up patrols in favor of beat cops in $1836 .{ }^{33}$

The City Guard was not without controversy. Contemporaries regularly complained about the use of force by guardsmen, even though they were armed only with swords. When a round of guardsmen encountered individuals, any physical altercation quickly became violent. ${ }^{34}$ Collectively, these accusations of police brutality marked New Orleans from the earliest period. ${ }^{35}$

On May 8, 1810, the New Orleans City Guard established a mandate for policing within New Orleans. Legislators asked the Guardsmen to pay particular attention to vagabonds, runaway slaves, and individuals disturbing the peace. The legislation also identified meetings of enslaved people in the markets and taverns of the city as new

32. New Orleans, Ordinances Issued by the City Council of New-Orleans: From the Promulgation of the Police Code Until the First of January 1812, with Two Acts of the Territorial Legislature, Relative to Said City, to Serve as a Supplement to the Police Code. (New Orleans, LA: Printed by Thierry, 1812), 48.

33. The "Ordinance Concerning the City Guard of New Orleans" in New Orleans, Ordinances Issued by the City Council of New-Orleans, 38 - 58; Rousey, Policing the Southern City, 13 - 37.

34. James Pirspond, New Orleans 29 June 1821, Charles F. Heartman Collection 1724 - 1897 (Suite 319, Building 38, Xavier University of Louisiana, 1 Drexel Drive, New Orleans, LA 70125, 1821).

35. The "Ordinance Concerning the City Guard of New Orleans" in New Orleans, Ordinances Issued by the City Council of New-Orleans, 38 - 58; Rousey, Policing the Southern City, 13 - 37. 
sources of disorder. Authorities felt that by policing slaves who drank in taverns or loitered in the city's markets after-hours, they could prevent smaller crimes from escalating to larger ones that threatened society or, at the very least, prevent lesser crimes from disrupting society. ${ }^{36}$

Collectively, the history of the legislation and the police forces highlights how significant enslaved people were to official constructions of order. Enslaved people were integral to New Orleans but contemporaries feared the presence of slaves could threaten public safety, economy, morals, and space. The New Orleans City Council created municipal codes responding to the enslaved population. The City Council also established a strong police presence to enforce such legislation. The New Orleans City Guard interpreted and applied the legislation to preserve order.

\section{Policing Slavery in Practice}

On December 12, 1809, G.T. Loeben sent the Report of the Captain of the Guards to Mayor James Mather. As a police administrator, Loeben was responsible for detailing the actions of the City Guard the previous night. His handwritten reports listed the names of those arrested, their status, the crime, and any supporting information. When replicated over days, weeks, and years, these types of accounts provided important insights into policing practices. On that day, Loeben accounted:

At 9:30[,] the first patrol arrested on Ursuline St. a negro named Jean Joseph. He said he was free.

At the same hour[,] the first Lieutenant, arrested on Bienville a negro name Joseph, belonging to Mr. Nagel.

36. "Ordinance Additional to that concerning the City Guard" in New Orleans, Ordinances Issued by the City Council of New-Orleans, 66 - 68. 
At 10:00[,] the police arrested a negress named Nagelline, who said she belonged to Mrs. Castillian. After we had examined her she showed us a bill which appeared to be counterfeit, and if it was not, it was still no good, as the law will not cash a bill over a month old.

After 10:00[,] the police found in the shop of Mr. Gillion a young negress named Celeste belonging to Julienne Lange, free negress. Said negress had runaway yesterday morning. The negro was named Sam, alias Williams was put in Jail for having consorted with enslaved people who had been arrested for theft...

P.S. Yesterday at four in the afternoon I arrested in the street a negro belonging to Mr. Collender, who had four cases of chalk which he was offering to sell at a price of one escalin each, which caused me to suspect said negro and arrest him. The negro had also stolen an arm from the arsenal, which was put back. ${ }^{37}$

As a complete record of the actions of the City Guard on December 12, 1809, the Report of the Captain of the Guards indicated how arrests happened in New Orleans. The City Guard was an active patrolling and preventative force. As they patrolled the city in rounds, they arrested individuals who they suspected had committed crimes. Once arrested, the round took these individuals to the central post for processing. At the central post, each arrested individual would be questioned and entered into the Report of the Captain of the Guard. If these individuals were people of color, they would be taken to the police jail. If not, they would be sent to meet with the mayor or police chief the following morning. As the City Guard arrested individuals they encountered at all hours of the night, the City Guard proved its worth as a preventative and patrolling force.

The various activities related in these records detailed the fine line between licit and illicit activities, the pressing problems of society, and how the police enforced their various codes of the City Council. As the ordinances of New Orleans City Council have indicated, contemporaries viewed the actions of enslaved people as an essential source of

37. "Report of the Captain of the Guards," Report of December 12, 1809, Charles F. Heartman Collection 1724 - 1897 (Suite 319, Building 38, Xavier University of Louisiana, 1 Drexel Drive, New Orleans, LA 70125, 1809). 
disorder within society. While the legislation signified that officials must guard against vagabonds, runaway slaves, and all those disturbing the peace, the records of the City Guard suggest that the application of such laws focused most on New Orleans' slave population. A random sampling of the arrest records within the Reports of the Captain of the Guards in 1809 showed that enslaved people made up a larger proportion of arrests than their population suggested. Although enslaved people made up 35\% of the total population of New Orleans, they made up $64 \%$ of arrests. ${ }^{38}$ Within these records, the New Orleans City Guard arrested enslaved people for property and public order crimes most commonly, $57 \%$ and $43 \%$ of the total arrests of slaves, respectively (See Table 3). Table 3: Arrest Records from the Reports of the Captain of the Guards in 1809

\begin{tabular}{|l|r|r|r|r|}
\hline Crimes & $\begin{array}{c}\text { Slaves } \\
\text { Arrested }\end{array}$ & $64 \%$ & $\begin{array}{l}\text { Free } \\
\text { People }\end{array}$ & $36 \%$ \\
\hline Property & 3 & $43 \%$ & 1 & $25 \%$ \\
\hline Public Order & 4 & $57 \%$ & 3 & $75 \%$ \\
\hline Total & 7 & & 4 & \\
\hline
\end{tabular}

Source: "Report of the Captain of the Guards," Charles F. Heartman Collection 1724 1897 (Suite 319, Building 38, Xavier University of Louisiana, 1 Drexel Drive, New Orleans, LA 70125, 1809).

These records suggest that the period presented opportunities for enslaved people. While it is impossible to ascertain motivations behind these alleged crimes, these statistics suggest two important trends. First, enslaved people did capitalize on the instability of

38. In the 1810 Census, slaves accounted for 5,961 of 17,242 inhabitants within New Orleans. There were only a few reports of the Captain of the Guards in 1809, these reports accounted for 5 days in December of that year. The current data set comes from the 11 arrests. Slaves made up $63.64 \%$ of arrests, or 7 arrests. Amongst those 7 arrests, the City Guard arrested enslaved people for marroonage twice, stealing twice, using false monies once, sleeping outdoors once, and illegally selling goods once. U.S. Census, Third Decennial Census; "Report of the Captain of the Guards." 
the era. Enslaved people used their freedom in and around the city. They ran away, stole, and participated in other illicit activities (See Table 3.A. in Appendix for a complete list of crimes). Second, although enslaved people broke laws with their actions, the arrest rate significantly exceeded the representative proportion of slaves. If order was something that needed policing, the New Orleans City defined their order largely in terms of enslaved people.

The practices of the New Orleans City Guard fed into the ordinances and laws of local officials. These Reports of the Captain of the Guards were a written barometer of policing and slavery within the city. With the information contained in these reports, the New Orleans City Council and the mayor went about refining their positions on public order and slavery. The City Council used reports, like the 1809 Reports of the Captain of the Guard, to craft future police codes. In those codes, the City Council went beyond traditional constructions of public order to prevent: avenues for runaway slaves and other forms of resistance in the markets and taverns of the city. Along with the city's ordinances, the arrest records signified that order was something fluid, defined not only in legislative halls, but also in daily, and especially nightly, encounters in the streets. ${ }^{39}$ While order depended on the actions of slaves, it also depended on public officials. When the City Council passed ordinances or the City Guard arrested individuals, they created norms for public order. In both cases, these norms rested upon the actions of New Orleans' slave population. When enslaved people ran up against official conceptions of public order, legislators and the police refined their positions. In

39. New Orleans, Ordinances Issued by the City Council of New-Orleans, 66 - 68. 
the following period, rebellion and warfare tested the limits of public order and official responses.

\section{Conclusion}

Between 1804 and 1811, the theory and, even more, the practice of policing revolved around slavery within New Orleans. The New Orleans City Council passed a number of ordinances that restricted the ways enslaved people lived, worked, and recreated. At the same time, the City Council expanded the mandate of the New Orleans City Guard. Accordingly, the city's enslaved people became an important focus of policing. The City Guard arrested enslaved people for all types of crimes, but most commonly for public order and property crimes. The pattern demonstrated that larger transformations took place within the New Orleans and the ways it policed slavery. New Orleans already began to come up with new ways to arrest, surveil, and police its slave population in the years after the Louisiana Purchase. While masters were responsible for the actions of their enslaved people, slaves themselves remained the focus of restrictions and punishments. This would not remain the case, however, as a new sense of public order emerged in the wake of multiple external threats to the city. Slavery remained a central concern, but who policed whom, and how, would shift in important ways. 


\section{CHAPTER 2}

Salvador

$1823-1835$

\section{Introduction}

On October 17, 1821, Maria Dundas Graham arrived in São Salvador da Bahia de Todos os Santos (Holy Savior of the Bay of All Saints) on the Northeast Coast of Brazil. Already the author of two published travel narratives, Maria Graham kept detailed notes later to be circulated as a Journal of a Voyage to Brazil, and Residence There, During Part of the Years 1821, 1822, 1823. The account within these notes provided extraordinary insights into life, society, and politics during a particularly turbulent time in the Portuguese Colony, which marked the early stages of rebellion that would ultimately become Brazilian independence (1821 - 1824).

Maria Dundas Graham's descriptions of slavery and urban life are most striking for those studying such themes. On October 20, Graham walked the city and commented on its various institutions: the government offices, the theater, and the hospital. The author also used the occasion to discuss Salvador's criminal justice system. She was thoroughly unimpressed with law enforcement, stating that the "police here is in a wretched state." While aware of the repercussions of the nascent independence movement and the weakened state of police forces, Graham suggested that several factors contributed to crime in Salvador: the distinctive landscape, a poor street lighting system, the unchecked power of royal officials, and the capricious nature of law enforcement. These criticisms not only reflected the perceptions of the visitor but alsorevealed major problems in Salvador. As Brazil emerged as an independent nation over the next several 
years, bureaucrats attempted to find the best way to promote order in Salvador. They looked at municipal institutions as anchors within society, particularly police forces. Therefore, policing slavery became an important project within notions of order in a newly independent Brazil. ${ }^{1}$

The chapter traces slavery within Salvador from the Brazilian independence (1823) to the Revolta dos Malês (1835), a revolt tied to enslaved and free Muslims of color in the city. Salvador was the commercial and political center of the province of Bahia. While the city grew along with the region's sugar and tobacco economies in the years before Brazilian independence, the development stagnated in the years after. Enslaved people were an important part of these changes within the city, as its main labor force. The overlapping systems of local, regional, and national government passed legislation and created institutions that sought to maintain an orderly slave population.

Provincial and municipal officials in Salvador attempted to order society through regulations and the creation of police institutions. One of the central aspects of the ordering focused on policing slavery. The establishment of the Corpo da Policia (1825), the Juiz da Paz (1827), and the Guarda Municipal Permanente (1830) created local institutions which interpreted and applied legislation created in Salvador's câmara (municipal and town council). The câmara passed many of the ordinances that guided slavery in Salvador during the period. It created regulations that sought to promote public safety through prohibitions on the slave population. Most of these laws focused

1. Maria Dundas Graham, Journal of A Voyage to Brazil, and Residence There, During Part of the Years 1821, 1822, 1823 (New York, NY: Frederick A. Praeger, 1969), 140 - 41. 
on policing the actions of enslaved people who could rebel or run away. ${ }^{2}$ The police forces then interpreted and applied these legal mandates in ways they saw fit.

Collectively, legislators and the police forces became the public face of policing slavery. ${ }^{3}$

Policing slavery was an essential concern for officials within Salvador prior to

1835. While a number of scholars have examined early nineteenth-century slavery in

Salvador, they have focused on its relationship to regional politics, and the transformation of slavery within national legislation. The scholarly emphasis on politicians-

particularly those holding high offices - and the law has minimized the role of local and regional officials. Similarly, while the actions of slaves surely influenced the politics of the era, scholars have rarely examined enslaved people's impact on local police responses. By looking at judicial and police records, the chapter squarely focuses on local officials, masters, and enslaved people to examine the policing of slavery. ${ }^{4}$

2. Aufderheide, "Order and Violence," 132; Alcides Passos Palma, ed., História Da Polícia Civil Da Bahia (Bahia, BA: Governo do Estado, 1978), 88 - 90; Thomas Flory, Judge and Jury in Imperial Brazil, 1808 - 1871 (Austin, TX: University of Texas Press, 1981), 50 - 60, 150 - 59; Roderick Barman, Brazil: The Forging of a Nation, 1798 - 1852 (Stanford, CA: Stanford University Press, 1988), 145 - 72; Holloway, Policing Rio de Janeiro, 49 - 50; Brown, “'On the Vanguard of Civilization'," 64; João José Reis and Hendrik Kraay, "'The Tyrant is Dead': The Revolt of the Periquitos in Bahia, 1824," Hispanic American Historical Review 89, no. 3 (2009): 399 - 434.

3. Graden, "An Act 'Even of Public Security”; Brown, “"A Black Mark on Our Legislation'”; Graden, From Slavery to Freedom in Brazil.

4. Aufderheide, "Order and Violence"; João José Reis, Rebelião Escrava No Brasil: A História Do Levante Dos Malês Em 1835 (São Paulo, SP: Companhia Das Letras, 1986); Filho, Mendigos, Moleques e Vadios; Brown, “'On the Vanguard of Civilization"'; Hendrik Kraay, Race, State, and Armed Forces in Independence-Era Brazil: Bahia 1790s - 1840s (Stanford, CA: Stanford University Press, 2001); Graden, From Slavery to Freedom in Brazil; Richard Graham, Feeding the City: From Street 
The chapter maintains that urban expansion played an important part in constructions of order. As Salvador expanded, so too did opportunities for individuals to cause disruptions within cities. Provincial and municipal officials in Salvador responded with legislation to control different individuals in the city. The growing slave population was one of the groups that influenced the theories and practices guiding order in early nineteenth-century Salvador. While there had been legislation about enslaved people by the eighteenth century, the growth of the city led to an expansion of such laws in the nineteenth century. Salvador's câmara created ordinances that attempted to protect public safety through preventative legislation and police practices. These laws prohibited enslaved people from many different activities: gambling, purchasing swords and daggers, carrying weapons, galloping horses, and gathering. Authorities sought to stop these particular threats from becoming larger threats to public order, like running away or rebellion. As police forces interpreted and applied the legislation, they also affirmed a focus on policing slavery through policing the slave community.

\section{Salvador}

By the time of Maria Dundas Graham's visit, commerce on the Bay of All Saints had already brought substantial demographic and economic growth to Salvador and the region. Salvador is situated on eastern side of the Bahia de Todos os Santos (Bay of All Saints), the second largest bay in the world, enclosing approximately 750 square kilometers of relatively placid waters. The bay provided the namesake for the province

Market to Liberal Reform in Salvador, Brazil, 1780 - 1860 (Austin, TX: University of Texas Press, 2010). 
in which Salvador is located—Bahia—and a safe and defensible harbor for the region's internal and external trade. The city had been the colonial capital of Brazil from the sixteenth to the eighteenth century. Although the Portuguese moved the colonial capital to Rio de Janeiro in 1763, Salvador remained Bahia's provincial capital. Salvador experienced substantial demographic and institutional growth in the nineteenth century, principally through a trade in cassava, sugar, tobacco, and slaves. ${ }^{5}$

Salvador functioned as an important economic center tied to the exportation of sugar and tobacco. On its docks, ocean-going vessels of the Bahian export economy mixed with canoes and boats carrying crops from the Recôncavo (Bahia's interior region). Fluctuations in global commodity prices at the end of the eighteenth century-as a result of the instability in Saint-Domingue that would ultimately produce the Haitian Revolution — provided an impetus for economic growth of agricultural commodities, including sugar. While Salvador exported 400,000 arrobas (a measure of weight equaling 14.75 kilograms) of sugar annually in the 1770 s, the trade expanded to 760,000 arrobas of sugar annually by the late-1790s. Economic growth continued to drive Salvador's annual exports of sugar to above one million arrobas by the 1820 s. $^{6}$

5. Stuart B Schwartz, Sugar Plantations in the Formation of Brazilian Society: Bahia, 1550 - 1835 (Cambridge, UK: Cambridge University Press, 1985); Maria José de Souza Andrade, A Mão de Obra Escrava Em Salvador 1811 - 1860 (São Paulo, SP: Corrupio, 1988), 9; B.J Barickman, Bahian Counterpoint: Sugar, Tobacco, and Slavery in the Recôncavo (Stanford, CA: Stanfored University Press, 1998); Richard Graham, Feeding the City.

6. The Haitian Revolution had important reverberations throughout the Atlantic, including Salvador. The 1791 slave rebellion set off a chain of events that drastically changed Saint-Domingue. The slave rebellion - and resulting universal emancipation in 1794 - drastically changed the economic outlook of the island and fostered factionalism 
Trade in tobacco initially experienced a similar growth but it eventually stagnated by the 1830 s. While merchants transported 320,000 arrobas of tobacco annually in the 1750s and 1760s, an average of 615,000 arrobas of tobacco left the port of Salvador by the 1780s. Tobacco exports began to trend downwards by 1815 , so that Salvador exported roughly 169,500 arrobas of tobacco by the early 1830 s. In subsequent years, both the sugar and tobacco economies in Bahia entered a phase of economic depression. ${ }^{7}$ Economic developments went hand-in-hand with demographic growth. While the population of Salvador had grown by roughly 20,000 inhabitants between 1724 $(25,000)$ and $1805(45,600)$, Salvador grew at a faster rate during the early nineteenth century. As Bahia's economy prospered, scores of people settled in Salvador. Although there were no censuses in Salvador between 1805 and 1872, scholars have projected a steady rate of growth between those dates. These scholars have suggested that Salvador

led by Toussaint Louverture in the Northern parts of Saint-Domingue and André Rigaud in the South. While under Louverture (1791 - 1802) the export economy rebounded, the instability throughout the rest of the Haitian Revolution effectively destroyed SaintDomingue's prominent sugar and coffee economies. This collapse drove global supply of sugar down and drove prices up. As a result, it created opportunity for tropical regions that could produce sugar, like Bahia and southern Louisiana. Sidney W. Mintz, Sweetness and Power: The Place of Sugar in Modern History (New York, NY: Penguin Books, 1985), 69 - 70; Ronald Angelo Johnson, Diplomacy in Black and White: John Adams, Toussaint Louverture, and Their Atlantic World Alliance, Race in the Atlantic World 1700 - 1900 (The University of Georgia Press, 2014).

7. Luís Antônio de Oliveira Mendes, "Discurso Preliminar, Historico, Introductivo Com Natureza de Descripção Economica Da Comarca e Cidade Da Bahia.," Anais Da Biblioteca Nacional Do Rio de Janeiro 27 (1905): 351; Stuart B Schwartz, Sugar Plantations in the Formation of Brazilian Society: Bahia, 1550 - 1835 (Cambridge, UK: Cambridge University Press, 1985), 573; Maria José de Souza Andrade, A Mão de Obra Escrava Em Salvador 1811 - 1860 (São Paulo, SP: Corrupio, 1988), 9; B.J Barickman, Bahian Counterpoint: Sugar, Tobacco, and Slavery in the Recôncavo (Stanford, CA: Stanfored University Press, 1998), 28 - 36. 
had a population of 62,980 inhabitants by $1830 .^{8}$ The demographic growth redefined the shape of the city and pushed the traditional boundaries of the Cidade Alta and the Cidade Baixa (upper and lower city, respectively).

Salvador's defining feature is a two to three hundred-foot ridgeline that divided the city into the Cidade Alta and Cidade Baixa, which was more than a physical barrier. The division between Cidade Alta and Cidade Baixa also functioned as a social barrier, albeit somewhat porous. The upper city was comprised of the freguesias (parishes) of Curato de Sé, Nossa Senhora da Vitória, São Antônio Além do Carmo, São Pedro, Santa do Sacramento, Santissimo Sacrmento do Rua do Passo, and Nossa Senhora de Brotas. On the raised land above the city, officials placed the governmental offices, courts, and military barracks. The upper city also had the Santa Casa de Misericórdia, a religiouslyaffiliated charity hospital. While the upper city had many of the city's institutions and residential neighborhoods, it was not a segregated area of the city. The upper city and its freguisias continued to be the center of Bahia in the years that followed. The lower city grew simultaneously. The lower city was divided into two parishes: Conceição da Praia and Pilar. It contained the Navy yard, the piers, warehouses, and markets of the city and,

8. Although an official census was not taken of the city until 1872, Salvador had an estimated population between 65,000 and 67,182 citizens in 1835 . Since regular censuses were not taken in Salvador, estimates of population have been compiled from sporadic censuses, estimating incremental growth. In Bahia: A Cidade Do Salvador e Seu Mercado No Século XIX, Katia Mattoso used censuses in 1805 and 1872 and estimated steady growth between the two dates. In Slave Rebellion in Brazil: The Muslim Uprising of 1835 in Bahia, João José Reis has taken a similar approach estimating a 1\% population growth between a census in 1808 and 1835. Katia M. de Mattoso, Bahia: A Cidade Do Salvador e Seu Mercado No Século XIX, Estudos Brasileiros (Salvador, Brazil: Secretaria Municipal de Educação e Cultura, 1978), 138; Reis, Slave Rebellion in Brazil, 6. 
therefore, it was the commercial hub of the town. The lower city also tended to be home to the merchants and enslaved people who worked there. ${ }^{9}$

\section{Slaves}

Salvador's slave population was an essential part of the growth of the city between 1824 and 1835. Enslaved people remained an important labor source. They worked in domestic occupations and groups dedicated to tasks in the city, called cantos. They also lived and worked within the city. As a significant portion of Salvador's population, enslaved people sometimes partook in actions that went against the norms of the public. Therefore, enslaved people and their actions forced a response from local government officials.

A random sampling of inventories in Salvador between 1800 and 1840 revealed that enslaved people labored in many different ways. Like the inventories in New Orleans, Salvador's inventories were created for the purposes of taxes and inheritance. Enslaved people made up a valuable proportion of the property of citizens in Salvador, as $77 \%$ of inventories contained at least one slave. Thusly, these inventories contained significant information about enslaved people and their value, including age, occupation, ethnicity, and any possible maladies. These records served as a way for officials to account for the transaction of enslaved people, particularly after a slaveowner's death. Yet for scholars, these inventories also indicated which types of occupations were most

9. de Casal, Corografia Brasílica, 89; Anna Amélia Vieira Nascimento, Dez Freguesias Da Cidade Do Salvador: Aspectos Socias e Urbanos Do Século XIX (Salvador, BA: Fundação Cultural do Estado da Bahia, 1986), 28 - 29. 
common for enslaved people. While slaves often worked in domestic occupations, they also performed a variety of jobs in the city (See Table 4). ${ }^{10}$

Table 4: Occupations of Slaves within Salvador's Inventories, between 1800 and 1840

\begin{tabular}{|l|l|r|l|}
\hline $\begin{array}{l}\text { Occupation } \\
\text { Groups }\end{array}$ & Occupations & Number & $\begin{array}{l}\text { Percentage } \\
\text { of Enslaved } \\
\text { People } \\
\text { working in } \\
\text { these } \\
\text { occupations }\end{array}$ \\
\hline Domestic & $\begin{array}{l}\text { Houseservant, Domestic, Tea } \\
\text { maker, Ironer, Washer, Seamstress, } \\
\text { and Servant. }\end{array}$ & 631 & $46.23 \%$ \\
\hline Agriculture & $\begin{array}{l}\text { Farmworker, Pickaxe Person, Sugar } \\
\text { Miller, Tobacco Tamper, and } \\
\text { Farmhand. }\end{array}$ & 240 & $17.58 \%$ \\
\hline Tradepersons & $\begin{array}{l}\text { Framer, Boilermaker, Lacemaker, } \\
\text { Carpenter, Cooper, Blacksmith, } \\
\text { Shoemaker, Mason, Tailor, and } \\
\text { Barber. }\end{array}$ & 150 & $10.99 \%$ \\
\hline Market & $\begin{array}{l}\text { Coachman, Sedan Carrier, Coffee } \\
\text { Grinder, Tobacco Roller, Day } \\
\text { laborer, Cashier, Breadmaker, and } \\
\text { Vegetable Seller. }\end{array}$ & 265 & $19.41 \%$ \\
\hline Sea Related & $\begin{array}{l}\text { Fisherman, Seaman, Sailor, Rigger, } \\
\text { and Shellfisherman }\end{array}$ & 43 & $3.15 \%$ \\
\hline Administrative & $\begin{array}{l}\text { Works for Customs, Police, } \\
\text { Military, and Patrol. }\end{array}$ & & $2.64 \%$ \\
\hline Total & & 1365 & \\
\hline
\end{tabular}

10. The list of occupations comes from a random sampling of inventories within Salvador from 1800 to 1840 . Of the 1381 total catalogued inventories between 1800 and 1840 , this data set is based upon a random sample of 251 records (or a $5.5 \%$ margin of error sample). Of these collective records, some 1202 enslaved persons had a recorded 1365 occupations. "Inventários Da Captial (1800 - 1888)," Seção Judiciária, Arquivos Do Estado Do Bahia (Salvador, BA). 
Source: “Inventários Da Capital (1800 - 1888)." Seção Judiciária. Arquivos Do Estado Do Bahia. Salvador, BA.

These occupations made Salvador's enslaved population an important component of the development of the city. They worked in the houses of Bahian elites, likely in the upper city, as nearly one-quarter of the slave population worked as either domestics or house servants. They lived and worked inside their masters' homes. They were also employed as hired-out cooks, ironers, and washers. Enslaved people also worked in sugar and tobacco fields directly surrounding the city and in the factories processing these commodities. A number of these enslaved people worked in skilled labor positions, as carpenters, masons, lacemakers, coopers, and boilermakers. Less skilled slaves worked as day laborers and transporters within the lower city. Through these various occupations, Salvador's slave population had access to all parts of the city (See Table 4.A. in the Appendix for a complete list of occupations). The presence of enslaved people throughout the city in these occupations was one aspect of Salvador's slavery that justified an expansive system of surveillance and policing.

Canto labor was one of the most unique forms of labor within Salvador. A Canto was a group of workers united by ethnic associations. These cantos performed a variety of different market-related work. As part of these cantos, enslaved people worked as carregadors de cadeira (sedan carriers, transporters, and couriers), barbers, cooks, and marketsellers. Collectively, these laborers and others defined Salvador throughout the early nineteenth century. ${ }^{11}$

11. Africa and the Americas, 280. 
Enslaved people lived and recreated in the city, just as they worked there. They inhabited the upper and lower city, living inside and outside their masters' homes. They celebrated local Catholic holidays and practiced Candomblé (an African-based religious community and practices) and capoeira (a martial arts practiced by people of African descent). ${ }^{12}$ They traded goods in the city's markets. Enslaved people occasionally mixed with free people in the city's taverns. These types of activities became the focus of subsequent legislation, which deemed them cardinal threats to public order. Officials took an interest in surveilling and policing the lives of enslaved people to prevent both serious threats (rebellious and runaway slaves) and minor disturbances to public welfare.

The perceived threat posed by Salvador's slave population had something to do with numbers, as the population grew throughout the period. The region had unprecedented levels of slave imports between 1798 and 1807. Roughly sixty thousand enslaved people came through Salvador in that period. ${ }^{13}$ While most of these enslaved people headed to plantations and farms in Bahia's interior, many remained in Salvador. Scholars have suggested that Salvador's population of enslaved people grew slowly until 1835. In that year, slaves made up an estimated $42 \%$ of the city's population. ${ }^{14}$ As enslaved people remained in Salvador, their actions were an important focus of local officials. As slaves lived, worked, and recreated it created opportunities to rebel,

12. Africa and the Americas, 280.

13. Schwartz, Sugar Plantations, 343 - 51.

14. João José Reis has estimated slaves made up $42 \%$ of Salvador's population by 1835, in which African slaves made up $26.5 \%$ and Brazilian slaves made up $15.5 \%$ of the total population. Graden, From Slavery to Freedom in Brazil, 1 - 16; Reis, Slave Rebellion in Brazil, 6. 
run away, resist, and threaten official conceptions of order. Local bureaucrats within the câmara passed legislation that limited the activities of enslaved people whenever those officials perceived a threat to public order. In the wake of Brazilian independence, liberal political ideology gave power to the câmara. The câmara responded by passing a number of ordinances aimed at controlling the slave population by limiting their actions that threatened or disturbed public order. Local police forces, in turn, interpreted and applied the legislation in years that followed.

\section{Independence and Liberalism}

Brazilian independence, 1821 - 1824, initiated a new era of politics. Independence and the formation of the Empire of Brazil created new institutions and political forces. These developments shaped not only the nation but how laws and institutions operated at a local level. In Salvador, national political events supported the authority of municipal and provincial officials. These institutions influenced the theories and practices behind policing slavery in Salvador.

Brazil had experienced a prolonged period of autonomy (1808 - 1820), when it became the home of the Portuguese court and emerged as an equal partner in within the Portuguese empire. When Napoleon threatened to conquer Portugal, the Portuguese crown fled to Rio de Janeiro and established a number of royal institutions in the colony, including royal militias and police forces. ${ }^{15}$ In 1815, Dom João VI (the Portuguese Regent) and his mother, Dona Maria I (the Portuguese Queen Regnant), sought to reward Brazil and seek assurances of its allegiance. On December 16, 1815, they elevated the

15. Algranti, "Slave Crimes"; Holloway, Policing Rio de Janeiro. 
status of Brazil from a colony to an equal partner in the United Kingdom of Portugal, Brazil, and the Algarves. While the Portuguese court created new militias and police forces in Brazil, many Brazilians feared what would happen to it if the court returned to Portugal. Brazilians realized these fears when events in Europe forced the Portuguese crown to return to Lisbon in the 1820 s.

Brazilian independence began in earnest in 1821, as King Dom João VI returned to Lisbon responding to pressures from the Cortes (Constitutional Assembly) in Portugal. Dom João VI left his son, Dom Pedro I, in Rio de Janeiro. While Brazil had gained political power in the early nineteenth century, the Portuguese Cortes passed a resolution to subordinate Brazilian provinces to Portugal. These actions outraged many Brazilians and, in response, they began to rebel. Dom Pedro I saw an opportunity in supporting the resistance movement, formally declaring independence from Portugal on September 7, 1822. While there were a number of regional struggles, in which local militias forced the Portuguese military out of Brazil, a relatively peaceful transition of power took place. Afterwards, Dom Pedro I named himself Emperor of Brazil and its constitutional monarchy, called the Empire of Brazil. ${ }^{16}$

16. Richard Graham, Patronage and Politics in Nineteenth-Century Brazil (Stanford, CA: Stanford University Press, 1990), 45 - 49; Holloway, Policing Rio de Janeiro, 28 - 63; Jeffrey Carl. Mosher, "Pernambuco and the Construction of the Brazilian Nation-State, 1831 - 1850," Ph.D. diss. (Gainesville, FL: University of Florida, 1996), 41 - 71; Emilia Viotti da Costa Costa, The Brazilian Empire: Myths and Histories (The University of North Carolina Press: Chapel Hill, NC, 2000), 1 - 23; Kirsten Schultz, Tropical Versailles: Empire, Monarchy, and the Portuguese Royal Court in Rio de Janeiro, 1808 - 1821 (New York, NY: Routledge, 2001). 
While the 1824 Brazilian Constitution harnessed political forces unleashed by independence, its implementation gave rise to political factions. Under the Constitution, the emperor remained the supreme executive, although the power was primarily exercised through appointed ministers of state and the General Assembly (Brazil's Congress). ${ }^{17}$ The Constitution also made promises to appease liberal political forces-who resisted central control—by promising the trial-by-jury and juiz de paz (locally-elected justice of the peace). ${ }^{18}$ However, Dom Pedro I largely failed to support these institutions. ${ }^{19}$ The failure to accommodate political aims gave rise to political parties in the early-1820s, as Brazil was divided between Conservative and Liberal political parties. While Conservatives largely supported the crown and centralization, Liberals championed regional autonomy. For his part, Dom Pedro I concerned himself with establishing diplomatic relations. In a trade agreement with Great Britain, for example, Dom Pedro I committed Brazil to the abolition of the Atlantic Slave Trade by 1831; however, Dom Pedro I lost control of domestic affairs, especially at the local level. The Brazilian General Assembly forced Dom Pedro I to institute the changes he had promised in the Constitution. Yet, the slow implementation of reforms did not appease Brazilian politicians. Dom Pedro I became increasingly unpopular and abdicated his throne in 1831, leaving Dom Pedro II regent of Brazil. Subsequently, the General Assembly

17. Barman, Brazil, 125.

18. Flory, Judge and Jury in Imperial Brazil, 49.

19. Barman, Brazil, 126 - 46. 
became the main political force. This General Assembly became the home of the Liberals and Conservatives who fought over the trajectory of Brazil. ${ }^{20}$

As a result of the national political jockeying, a unique period of profound local autonomy emerged in Salvador in the 1820 s and the 1830 s. The city's câmara became the main legislative institution within the city and its laws. The câmara established different ordinances to order slavery within Salvador. At the same time, provincial officials created several different police organizations to police slavery and enforce ordinances.

\section{Police Organization}

Within the larger political climate, provincial and municipal officials created a strong legislative and institutional presence in Salvador. Salvador's câmara responded to local concerns and the city's slave population; so too did the creation of the Corpo da Policia (1825), Juiz da Paz (1827), and the Guarda Municipal Permanente (1830). The Corpo da Policia, Juiz da Paz, and the Guarda Municipal Permanente became the face of the local governmmment that interpreted and applied legislation.

In 1825, Salvador made its first major step in the years after Brazilian independence to establish a formal police force. Dom Pedro I created the Corpo da Policia (Police Corps) within Salvador in response to the Revolta dos Periquitos, a revolt of black and mulatto military regiments within the city. The institution was an offshoot of the Guarda Real (Royal Guard), a police force formed in Rio de Janeiro in 1809. The Corpo da Policia was responsible for maintaining order and enforcing posturas

20. Flory, Judge and Jury in Imperial Brazil, 150 - 59; Barman, Brazil, 168. 
(municipal ordinances). The police regiment was comprised of three companies. Each company reported to a police intendant. The Corpo da Policia had two main charges: to catch people in the commission of crime and to execute warrants for the police intendant. While government officials expected the institution to protect the city from disorders, reformers often accused police intendants of corruption. They felt that the Corpo da Policia became a personal militia of the police intendant rather than protectors of good order. National reforms created another layer of police bureaucracy in subsequent years. ${ }^{21}$

Fulfilling a promise Dom Pedro I had made in Brazil's Constitution (1824), officials in Salvador established the office of Juiz da Paz. Electors in each freguesias voted for a Juiz da Paz. The justice of the peace was an arbitrator between two parties in potential lawsuits. Yet, because of the broad wording of the Constitution, the Juiz da Paz had a variety of responsibilities: breaking up gatherings, assembling evidence in criminal cases, pursuing known criminals, interrogating suspects, enforcing posturas, and preventing runaway communities. ${ }^{22}$ In 1830, provincial officials created the Guarda Municipal Permanente (1830) to supplement the Juiz da Paz. The expansive powers of

21. Aufderheide, "Order and Violence," 132; Brown, “'On the Vanguard of Civilization'," 64; Reis and Kraay, “"The Tyrant is Dead”; Palma, História Da Polícia Civil Da Bahia, 88 - 90.

22. Flory, Judge and Jury in Imperial Brazil, 59 - 60. 
the Juiz da Paz and the Guarda Municipal Permanente made them central figures in regional policing and governance. ${ }^{23}$

Local legislators created many of the initial regulations that ordered slavery and its policing in Salvador's câmara. On February 25, 1831, the câmara passed three provisions pertaining to enslaved people. These ordinances focused specifically on the actions of enslaved people at leisure. Postura 86 held that enslaved people were to dispose trash at certain hours during the night. Postura 87 established fines for houseowners and tavernkeepers who allowed enslaved people to gamble on their property. Postura 88 prohibited batuques (drum circles), dances, and gatherings of enslaved people. These posturas did more than prohibit specific actions. They sought to address smaller concerns for public health and public morals that disrupted official conceptions of order. At face values, these ordinances aimed at annoyances in society; however, these actions could also serve as the pretext for catastrophic disorders. In the case of Postura 88, these gatherings were not only disruptive to the quiet but could be part of larger resistance movements. By prohibiting or breaking up slave gatherings or gambling, the police could intercede before these crimes became the pretenses to commit other more serious crimes. ${ }^{24}$

23. Flory, Judge and Jury in Imperial Brazil, 50; Barman, Brazil, 145; Holloway, Policing Rio de Janeiro, 50.

24. Arquivo Minicipal de Salvador, Repertório de Fontes Sobre a Escravidão Existentes No Arquivo Municipal de Salvador as Posturas (Salvador, Bahia, Brazil: Fundação Gregório de Mattos, Prefeitura Municipal do Salvador, 1988), 48 - 49. 
Around the same time, the câmara passed several different ordinances to better order enslaved people within Salvador. In 1833, the câmara established prohibitions against selling knives, swords, and blades and firearms to enslaved people. These ordinances also barred enslaved people from taking part in otherwise-sanctioned games and punished enslaved people who galloped horses through the city. These posturas were fairly straightforward. Government officials attempted to prevent the actions of enslaved people from becoming serious violent crimes. ${ }^{25}$

Collectively, the history of the legislation and the police forces highlighted how significant enslaved people were to order in the period. Enslaved people were integral to Salvador's social life and economy but authorities still feared that enslaved people could threaten public safety, morals, and public space. Salvador's câmara created codes responding to the enslaved population, as provincial authorities established a strong police presence to enforce such legislation.

\section{Policing Slavery in Practice}

In 1831, João Lourenço Suixaz, the Juiz da Paz in the neighborhood of Conceição da Praia - a fregusia in the lower city — sent monthly reports to the Prezidente (Governor) of Bahia, Honorato José de Barros Baim. In his record of October, Suixaz included the following reports of criminals and punishment:

Joaquim Manoel, found with a dagger, condemned to 60 days on October 13 Luiz S. Anna who deserted and stole, sent to the Prezidente with legal summary October 8 Other black fled Joaquim corrected, freed. $-49$.

25. Arquivo Minicipal de Salvador, Repertório de Fontes Sobre a Escravidão, 48 
Rita, and Joanna, these prisoners stole, released. Luiz justified their conduct. Antonio and Francisco, found trying to circulate false coin, sent to the criminal judge.

Marcelino Periero, corrected, freed.

Andre, Liuza, and Honorio, vagabonds, sent to work on the train.

Diego, Negro, larceny.

Maria Euferni, hurt a man, sent to the criminal judge.

Slave of Silvo, resisted the patrol.

Francisco, Negro, and Iguar, disorder.

Luiz Antonio de Carvalho, passed false notes, freed.

Manoel Grs. dos Santos, fought with another, freed.

Caetano Rios, broke postura number 6

Theodorio Rivers, found with a knife edge. ${ }^{26}$

Although the report only accounted one encounter with enslaved people, it highlighted exactly how the Juiz da Paz in Conceição da Praia surveilled, arrested, punished, and referred arrestees to other provincial legislators. At the most basic level, these records suggest that these writings originated in the personal notes of the Juiz da Paz. They were informal, incomplete, and often unspecific. They sometimes failed to take account of individual's names. At others, they failed to note the crime or punishment. These records also imply that the Juiz da Paz acted as an intermediary police official. Individuals arrested, likely by the Guarda Municipal Permanente, appeared before the Juiz da Paz. It would be the official's responsibility to figure out how to correct arrestees and to determine whether or not their cases required a trial in front of other judicial officials. In this way, the Juiz da Paz decided how to preserve the order suggested by provincial legislation. In short, from their position in the various freguesias, the Juiz da Paz became an integral part of policing Salvador.

26. João Lourenço Suixaz, João Lourenço Suixaz to Prezidente do Provincia, Juizes de Paz 1 Vara, Arquivos Do Estado Do Bahia (Salvador, BA, 1831). 
While the report of the Juiz da Paz only represents a thin slice of crime within the city, being a record of two months of a single police official in a single freguesia, it does depict a law and order in action under the jurisdiction of the Juiz da Paz. These arrests indicate that there was a focus on public order crimes within Salvador. Yet, the Juiz da Paz did not blindly enforce the dictates of the câmara. The Juiz da Paz, like other police forces, decided how to best promote good order in relation to the actions of enslaved people and the ordinances passed by local officials.

From the records of the Juiz da Paz in Conceição da Praia, two major patterns emerged. First, people identified as enslaved people made up a smaller percentage of the arrest records than their population would suggest: enslaved people made up $24 \%$ of the arrests. Since enslaved people made up roughly $42 \%$ of the Salvador's population around 1835 , the $24 \%$ arrest rate falls well below the proportional population of Salvador. ${ }^{27}$ While enslaved people were not the sole focus of the police, they did influence Salvador's policing efforts. Second, these reports also represented a broader trend in Salvador; enslaved people were most commonly arrested for crimes against public order (See Table 5).

27. Suixaz, João Lourenço Suixaz to Prezidente do Provincia; Suixaz, João Lourenço Suixaz to Prezidente do Provincia; Reis, Slave Rebellion in Brazil, 6. 
Table 5: Juiz da Paz, Conceição da Praia, "Relação do Prezos", September - October 1831

\begin{tabular}{|l|r|r|r|r|}
\hline Crimes & $\begin{array}{l}\text { Slaves } \\
\text { Arrested }\end{array}$ & $29 \%$ & $\begin{array}{l}\text { Free } \\
\text { People }\end{array}$ & $71 \%$ \\
\hline Violent & 1 & $9 \%$ & 5 & $19 \%$ \\
\hline Property & 4 & $36 \%$ & 3 & $11 \%$ \\
\hline Public Order & 6 & $55 \%$ & 15 & $56 \%$ \\
\hline Unknown & 0 & $0 \%$ & 4 & $15 \%$ \\
\hline Total & 11 & & 27 & \\
\hline
\end{tabular}

Sources: Suixaz, João Lourenço. João Lourenço Suixaz to Prezidente do Provincia. Juizes de Paz 1 Vara. Arquivos Do Estado Do Bahia. Salvador, BA, 1831; Suixaz, João Lourenço. João Lourenço Suixaz to Prezidente do Provincia. Juizes de Paz 1 Vara. Arquivos Do Estado Do Bahia. Salvador, BA, 1831.

João Lourenço Suixaz reprimanded and punished free persons for a variety of crimes, including insulting the patrol, fighting, vagabondage, passing false notes, carrying weapons, robbery, theft, and injuring others. The Juiz da Paz arrested enslaved people for slightly different crimes. These types of crime break down into larger forms: public order, violent, and property crimes. In September and October of 1831, Suixaz arrested enslaved people for public order (55\%), violent (9\%), and property crimes (36\%). Suixaz most commonly arrested slaves for public order crimes, represented by running away and quilombo (or living amongst other runaway slaves in properties and communities) in these records (See Table 5.A. for a complete list of reported crimes). The reports of the Juiz da Paz also contained several arrests for theft. Only one enslaved person came before the Juiz da Paz for a crime of violence. The crime statistics 
represented in the 1831 reports of João Lourenço Suixaz mirrored arrest records in the years that followed. ${ }^{28}$

The records of the Juiz da Paz suggest that Salvador presented a variety of opportunities for enslaved people to engage in behavior that challenged constructions of public order, even when, or especially when, they did not pose violent threats to other people's personal safety. It is clear that some enslaved people used their freedom in and around the city to commit crimes. They ran away and lived with other runaways. They stole from other individuals. They fought. In response, Salvador's câmara passed a number of new posturas to prevent these types of actions. As justices of the peace and other police forces attempted to engage enslaved people, they interpreted and applied the legislation of the câmara. The types of arrest records signified that order was something fluid, defined not only in legislative halls, but also in daily, and especially nightly, encounters in the streets.

While order depended on the actions of slaves, it also depended on public officials. When the câmara passed ordinances or police officials arrested individuals, they created norms for good order. In both cases, these norms rested upon the actions of Salvador' slave population. As enslaved people continued to challenge those norms, officials created new theories and practices. In the following period, new challenges again tested the limits of public order and official responses.

28. João Lourenço Suixaz, João Lourenço Suixaz to Prezidente do Provincia, Juizes de Paz 1 Vara, Arquivos Do Estado Do Bahia (Salvador, BA, 1831); Suixaz, João Lourenço Suixaz to Prezidente do Provincia; Reis, Slave Rebellion in Brazil, 6. 


\section{Conclusion}

Between 1823 and 1835, the theory and practice of policing revolved around slavery within Salvador. Salvador's câmara passed a number of posturas that restricted the ways enslaved people lived, worked, and recreated. The câmara also expanded the mandate of the Corpo da Policia, Juiz da Paz, Guarda Municipal Permanente, and the Guarda Nacional. As a result, enslaved people became a focal point of policing. While enslaved people did not monopolize the arrest records, these posturas suggested that enslaved people did play a critical part in official constructions of order. After independence, Salvador already began to come up with new ways to arrest, surveil, and police enslaved people by regulating different threats to public order. However, at this time, enslaved people remained the main focus of restrictions. In the years that followed, as series of events threatened Salvador, local officials sought to protect public welfare through regulations on enslaved people and the individuals who interacted with these slaves. 


\section{PART II}

Police Forces and the Policing of Slavery

In the second period-1811 to 1815 in New Orleans and 1835 to 1838 in Salvador - each city responded to slave rebellions and political instability by establishing new systems of public order based upon comprehensive senses of responsibility for the actions of enslaved people. The German Coast Rebellion (1811) and the Revolta dos Malês (1835) shook New Orleans and Salvador. These events challenged the earlier theories and practices guiding the policing of slavery. New laws and institutions asserted a new authority over the welfare of each city. The legislation regulated not only slaves but their masters. At the same time, these laws justified police intervention into the slave-master relationship when public order required it. 


\section{CHAPTER 3}

New Orleans

$1811-1815$

\section{Introduction}

On January 10, 1811, “a gentleman in New Orleans" wrote a letter to his friend in Chester, Pennsylvania. In the correspondence, the gentleman provided an account of the Deslondes or German Coast Rebellion (January 8 - 10, 1811). The rebellion of an estimated one hundred fifty to five hundred enslaved people had serious repercussions on the city as the rebels marched towards New Orleans. The gentleman suggested that the imminent attack threw New Orleans "into the utmost dismay and confusion." While the rebellion was ultimately unsuccessful, the specter of rebellious slaves incited responses from the New Orleans City Council and the New Orleans City Guard. These officials established an inclusive system of policing slavery. However, this slave rebellion was just one of the events that influenced official constructions of order in New Orleans and Louisiana in the years that followed.

Shortly after the German Coast rebellion, the War of 1812 also created instability in New Orleans, because-Louisiana and the Mississippi River were theaters in the war between the United States and Great Britain. The actions of enslaved people in both of these contexts challenged the efforts of local officials to preserve public welfare. The New Orleans City Council and the New Orleans City Guard responded through a series

1. "Insurrection in Orleans. Extract of a Letter from a Gentleman in New Orleans to His Friend in Chester, Pennsylvania," Columbian 407 (21 February 1811): 3. 
of changes in legislative and policing practices. Policing focused on preventing enslaved people from running away and rebelling. However, legislators also sought to regulate negligent masters and free people of color to order slavery in New Orleans.

Economic growth, immigration, and statehood influenced officials in New Orleans in the early 1810s. As capital, commodities, and inhabitants arrived in New Orleans, the city's growth subtly eroded the political power of Creoles. While these Creoles continued to control New Orleans City Council, the city was slowly becoming an American city. As a result, the City Council had to start accommodating others in New Orleans. At the same time, growth also corresponded to an expansion of the slave population within New Orleans. Authorities felt that if they failed to regulate and police slavery, enslaved people could threaten the security of the city by running away and rebelling.

The German Coast Rebellion and the War of 1812 allowed legislators and the police in New Orleans to expand upon previous theories and practices guiding the policing slavery. The specter of rebellious and runaway slaves proved to be a powerful force in the city. Officials saw the destructive force that the German Coast Rebellion unleashed. Fearing another uprising, the City Council passed ordinances that sought to limit the communication and mobility of enslaved people. Authorities also created a new form of enforcement for the City Guard. The City Council mandated that the City Guard surveil and police private properties and residences, without the consent of property owners. Fears of runaway and rebellious slaves remained throughout the War of 1812, as local officials and city elites fretted that enslaved people, free blacks, and pirates might 
join the British to subvert Louisiana's wartime efforts. Collectively, legislators and the police promoted a heavy-handed approach to policing slavery throughout the era.

Municipal and police officials refined their system of public order in New Orleans between 1811 and 1815 . The chapter adds another dimension to what we already know about slavery in New Orleans by pointing to the City Council and the City Guard as factors in the relationship between enslaved people and their owners. Many historians have discussed the legal and political changes within New Orleans and Louisiana and their effects on the trajectory of slavery. However, the body of literature has mainly focused on the transition between French, Spanish, and American legal codes. Those works have not explored the implementation of such laws. ${ }^{2}$ The chapter brings municipal institutions into a discussion with these larger legal transitions. Through this approach, the theories and practices of formal authority become clear in New Orleans. The municipal records indicate that enslaved people and slavery played a large part in the constructions of public well-being. While the New Orleans City Council crafted a number of ordinances that circumscribed the actions of enslaved people in the city, the City Guard used these codes to police slavery. The collective actions of the City Council

2. James H. Dormon, "The Persistent Specter: Slave Rebellion in Territorial Louisiana," Louisiana History 18, no. 4 (Autumn 1977): 389 - 404; Schafer, Slavery, The Civil Law, and the Supreme Court of Louisiana; Rousey, Policing the Southern City; Ingersoll, Mammon and Manon in Early New Orleans; Junius Rodriguez, "Rebellion on the River Road: The Ideology and Influence of Louisiana's German Coast Slave Insurrection of 1811," in Antislavery Violence: Sectional, Racial, and Cultural Conflict in Antebellum America, John R. Mckivigan and Stanley Harrold (Knoxville, TN: The University of Tennessee Press, 1999), 65 - 88; Schafer, Becoming Free, Remaining Free; Kastor, The Nation's Crucible; Spear, Race, Sex, and Social Order in Early New Orleans; Scott, "Paper Thin"; Daniel Rasmussen, American Uprising: The Untold Story of America's Largest Slave Revolt (New York, NY: HarperCollins Publishers, 2011). 
and City Guard amended the comprehensive system of regulating and policing slavery to account for masters and others who were connected to the slave population.

The chapter further holds that urban expansion influenced slave laws and policing within early nineteenth-century New Orleans. American expansion and commercial growth — particularly related to sugar and cotton—poised New Orleans for development. Growth and subsequent warfare created new opportunities for enslaved people. New Orleans' enslaved population seized these opportunities, rebelling and running away. These types of slave resistance were not new, of course, but they had new meanings in the era of preventative policing. In response, legislators responded with legislation that protected public safety through an expansion of policing beyond the slave population, which called for the surveillance of masters, free people of color, and other working-class individuals. In policing those that had contact with the slave community, public authorities sought not just to regulate the actions of individual enslaved people, but to order the institution of slavery in a systemic fashion.

\section{Growth and Statehood}

The period between 1811 and 1815 was one of growth for Louisiana.

Commercial and demographic development also defined New Orleans. Yet, development also initiated a slow transition of political power. As Louisiana became a state, demographic and economic expansion forced the New Orleans City Council to be more responsive to its inhabitants and their actions.

Commercial and demographic growth marked New Orleans between 1811 and 1815. Growth meant that government officials had more assets and inhabitants to protect, as they sought to promote public welfare. While it is impossible to ascertain the 
degree to which the War of 1812 disrupted New Orleans, statistics surrounding the period suggested the city continued to expand in the first years of the 1810s. Commodities continued to flow to the docks of New Orleans. Trade in sugar, cotton, and other goods increased around eighteen-fold from the time of the Louisiana Purchase to 1815. While exports of New Orleans averaged about $\$ 538,250$ in the final years of Spanish rule, exports totaled $\$ 9,749,253$ in 1815 . This trade made New Orleans one of the principal ports of the United States. ${ }^{3}$ The rapid commercial growth led to population increases within New Orleans. The United States Censuses suggests that the population of New Orleans increased by 10,000 inhabitants between 1810 and 1820. Americans, SaintDominguans, immigrants, and slaves also settled in New Orleans during the War of 1812. These rapid growths created problems for government authorities, who wanted to preserve orderly social relations within New Orleans. ${ }^{4}$

Expansion also influenced who was in charge of the government institutions responsible for public order. As Louisiana grew, the United States made Louisiana its eighteenth state in 1812. Statehood also altered the balance between Americans and Creoles in state and municipal politics. While Creoles retained control of the City

3. Between 1799 and 1802, New Orleans exported a total of $\$ 2,153,000$ for an annual average of $\$ 538,250$ dollars. By 1815 , the Port of New Orleans was exporting $\$ 9,749,253$ in commodities. Sibley, An Account of Louisiana, 65 - 66; John Adams Paxton, The New-Orleans Directory and Register (New Orleans, LA: J.A. Paxton, 1822), 27.

4. While New Orleans had 17,242 inhabitants in 1810 , these numbers grew to 27,176 by 1820 . It is only reasonable to assume that the growth did not all occur in the final years of the era. U.S. Census, Third Decennial Census, 82, 295; U.S. Census, Fourth Decennial Census (Washington, D.C.: Gales \& Seaton, 1821), 81. 
Council, Americans started to challenge their authority. Collectively, statehood marked an opening of New Orleans politics. By the 1830s, state legislators had experimented with moving the state capital and splitting up New Orleans to cut Creoles entirely out of the political landscape of Louisiana. ${ }^{5}$

Economic growth, immigration, and statehood profoundly influenced New Orleans in the early 1810s. The rapid development of New Orleans also challenged official conceptions of order. As new monies, people, and political powers defined New Orleans, maintaining orderly social relations required a greater police presence.

Government officials had to respond to these pressures. However, the contemporaneous German Coast Rebellion and the War of 1812 proved to officials that public safety rested upon controlling slavery within these larger transitions.

\section{Slaves in Rebellion and War}

The growth of the city, a slave rebellion, and the War of 1812 had repercussions on law enforcement in New Orleans between 1811 and 1815. The population of enslaved people grew along with the city, as it had after the Louisiana Purchase. Yet, the German Coast Rebellion and the War of 1812 had a significant role within conceptions of order in New Orleans. These events accelerated earlier tendencies towards comprehensive legislation and institutions that policed slavery. While the City Guard continued police slavery in New Orleans, the ordinances that they enforced took on a new method. Local officials began to assume some of the responsibilities of slaveownership. In practice, this 50.

5. Dargo, Jefferson’s Louisiana, 171 - 75; Kastor, The Nation's Crucible, 130 - 
entailed surveilling and policing those connected to the slave population: free people of color, immigrants, and slave owners.

As New Orleans expanded commercially and demographically in the 1810 s, the slave population also increased. The population of enslaved people expanded from 5,961 to 7,335 between 1810 and 1820 . However, despite the growth in real numbers, the enslaved population did not keep pace with the influx of Americans and immigrants. Slaves made up $35 \%$ of the population in 1810 , but only $27 \%$ in $1820 .{ }^{6}$ Nonetheless, enslaved people remained an important part of the city's labor force.

Enslaved people were a significant part of the development of the city. They continued to labor in the houses and the streets. Their labor was responsible for the unloading and controlling commodities on the city's docks. At the same time, officials used slaves, stationed in the police jail, to repair the city's infrastructure and prepare the ramparts during the War of 1812 . They also remained active in the city's streets, markets, and religious ceremonies.

A slave rebellion, attributed to Charles Deslondes, struck fear into the inhabitants of New Orleans on the night of January 8, 1811. Deslondes and a group of enslaved people attacked the Andry plantation on the German Coast, approximately 36 miles upriver from New Orleans. These rebels united and marched towards New Orleans with some semblance of discipline. Planters and their families fled from the surrounding countryside to New Orleans. Governor Claiborne dispatched the Louisiana militia and

6. U.S. Census, Third Decennial Census, 82, 295; U.S. Census, Fourth Decennial Census, 81. 
the U.S. Army stationed in Louisiana in response. These forces met the rebels on the Destrehan plantation on January 11, 1811. There, the U.S. Army and the Louisiana militia ended the rebellion by killing some sixty enslaved rebels. While the rebellion caused considerable damages to the plantations along Louisiana's German Coast, the rebellion failed to reach New Orleans. Nonetheless, the German Coast Rebellion shattered New Orleanian's perceptions of an orderly slave population. Authorities reacted with a shift from policing the actions of individual slaves to surveilling and policing the slave population and the masters integral to it.

Historians have argued that the event created an immediate backlash; but in fact, changes were slow to come. The first long-standing legal reforms came nearly twelve months later. Nonetheless, the rebellion did mark a transitional period for public order and municipal slave ordinances. The City Council established restrictive prescriptions and proscriptions for enslaved people in the city. ${ }^{7}$ While Louisianans had seen rebellion before, the response of the New Orleans City Council was unique. The City Council passed new types of laws focused on controlling slavery through the slaves and their masters. ${ }^{8}$

On February 15, 1812, the New Orleans City Council passed an ordinance that provided practical solutions for limiting the places enslaved people could live and

7. "Insurrection in New Orleans"; Rodriguez, "Rebellion on the River Road"; Robert L. Paquette, “"A Horde of Brigands?': The Great Louisiana Slave Revolt of 1811 Reconsidered," Historical Reflections/Réflexions Historiques 35 (2009): 72 - 96; Rasmussen, American Uprising.

8. Paquette, “"A Horde of Brigands?," 81. 
assemble. While it was an expanded version of earlier ordinances, the law also created an inclusive sense of responsibility because it contained a number of articles directed at slaveowners. Individual owners could no longer be trusted to judge the honesty and loyalty of their enslaved people. Legislators punished masters for letting enslaved people live outside of their homes and chastised masters who let groups of slaves congregate on their property. Moreover, these articles also established a new prerogative for the City Guard, allowing them to "enter...into any house or lot where enslaved people shall be so gathered." ${ }^{9}$ While the ordinance did not pinpoint new sources of slave disorder, the wider construction of responsibility created a new era of slave relations in the city. In the name of public safety, the ordinance allowed government officials to enter property without the consent of property owners. The municipality sought to rein in some of the actions of individuals who owned slaves, particularly when these actions were detrimental to public welfare. When masters allowed enslaved people to congregate or live outside their homes, for example, officials felt that these masters enabled slaves to resist, rebel, and commit crimes. With this legislation, the City Council attempted to give the City Guard tools to control the city and by extension the slavery within it.

During the War of 1812, official concerns for the slave population remained an important force in legislating and policing New Orleans. While the German Coast rebellion and subsequent ordinances highlighted municipal intervention into policing enslaved people, it also marked anxiety about a disorderly population of slaves. The fear

9. New Orleans, Ordinances Issued by the City Council of New-Orleans, 84 - 90; Paquette, “"A Horde of Brigands?," 81. 
became both palpable and visible in the years that followed. During the War of 1812 with the threat of British invasion of New Orleans and the Mississippi River-military commanders, politicians, the New Orleans City Council, and the City Guard expressed concern regarding enslaved people. Governor W.C.C. Claiborne related the fears of many New Orleanians within the context of enticing General Andrew Jackson to come to New Orleans:

Louisiana has at the moment much to apprehend from Domestic Insurrection; We have every reason to believe that the Enemy has been intriguing with our enslaved people, and from a variety of circumstances, we have much cause to suspect that they on their part, mediate mischief. ${ }^{10}$

In the quote, Claiborne clearly identified a multifaceted fear. As the British advanced throughout the Gulf of Mexico and towards New Orleans, they compounded official fears about the slave population. While runaway and rebellious slaves threatened official conceptions of order, the threat multiplied in unison with a British invasion. The New Orleans City Council concluded that it was "advisable for the maintenance of order and the City's safety, that some measures of police relative to enslaved people and free colored persons should be taken." curfew to 7 P.M. and even required all free blacks to register with the city to obtain "a

10. W.C.C. Claiborne, "Governor Claiborne to Jackson," in Correspondences of Andrew Jackson, vol. II: May 1, 1814 to December 31, 1819, ed. John Spencer Bassett (Washington, D.C.: Carnegie Institution of Washington, 1814), II: May 1, 1814 to December 31, 1819:55 - 56.

11. "Proceedings of the Conseil de Ville," 8: 24 - 25, Louisiana Division (New Orleans Public Library), 24 - 25; Kastor, The Nation's Crucible, 173. 
'safety pass' to prove they were not runaways." ${ }^{12}$ These measures created a form of martial law that made people of color easier to surveil and police. Authorities felt that all enslaved people were seen as potential recruits to the British and, therefore, responded with a strong-handed approach to policing slavery. Government officials formed a control mechanism that lasted until the danger of British invasion ceased, as Americans defeated the British in the Battle of New Orleans.

While preparations for warfare took place along the Mississippi River throughout 1814, the British invasion still did entice enslaved people to run away. ${ }^{13}$ While there are not estimates of the numbers of slaves who ran away, a number of enslaved people escaped their owners for the British forces in Louisiana. There were a significant number of runaways that W.C.C. Claiborne and General Andrew Jackson led a mission to retrieve them. Yet, the British emancipated these individuals and relocated them to islands within their empire, particularly Bermuda and Trinidad. While few slaves returned to Louisiana, Claiborne and Jackson cobbled together a policy of compensating slaveowners for their

12. Kastor, The Nation's Crucible, 173; W.C.C. Claiborne, "Claiborne to Choctaw Chief, August 1812," in The Letter Books of William C.C. Claiborne, 1801 1816, vol. 6, ed. Dunbar Rowland (Jackson, MS: Mississippi State Library and Archive, 1917), 153 - 55; W.C.C. Claiborne, "Claiborne to Brown, 27 July 1813," in The Letter Books of William C.C. Claiborne, 1801 - 1816, vol. 6, ed. Dunbar Rowland (Jackson, MS: Mississippi State Library and Archive, 1917), 245 - 46; Holmes, "Holmes to Wilkinson, 7 September 1812," in The Territorial Papers of the United States, vol. 6, ed. Clarence Edward Carter (Washington, D.C.: U.S. Government Printing Office, 1934), 320 - 21.

13. Gene Allen Smith, The Slaves' Gamble: Choosing Sides in the War of 1812 (New York, NY: Palgrave Macmillan, 2013), 165. 
runaways. Rather than recovering slaves or providing new ones, government officials paid slaveowners for their loss of their slaves. ${ }^{14}$

Between 1811 and 1815, the actions of legislators created a new order. In response to a slave rebellion and warfare, the City Council and W.C.C. Claiborne established a stronger police mandate. In order to prevent rebellions and slaves from running away, the City Guard was to surveil and police not only enslaved people, but also free people of color and slaveowners. In the years that followed, the system of surveillance would endure and justify yet more expansive ways of policing slavery.

\section{Policing Slavery in Practice}

On November 12, 1814, New Orleans Police Commissioner Louis Nicholas sent a complete report of the actions taken by the City Guard the night prior to the mayor. In the document, Nicholas accounted:

At 7 hours[,] Mr. Lorda required a man of the guard to arrest one of his negresses named Ursule, and she was put in the jail.

At 8 hours[,] the commissioners of the police led to the Post, the negroes W. Say belonging to Mr. Cadet Moulou; Auguste belonging to Jaoćhem Courcellle; François belonging to Mr. Turcas; Applollon belonging to J. Courcelle; Joseph to Cheion; Jacques or François to Madame. Ve. Domingue; Eveillé to Mr. Bouligny; they were arrested in a house situated on rue Dauphiné, forming a pernicious society in the colony; they were put in the jail. All the utensils of the order and a pistol were brought to the post.

At 9 hours[,] the commissioners of the police brought to the post, the negro named Charles belonging to Mr. Demarche, the negro was put in the jail.

14. W.C.C Claiborne, "Governor Claiborne to Jackson," in Correspondences of Andrew Jackson, vol. II: May 1, 1814 to December 31, 1819, ed. John Spencer Bassett (Washington, D.C.: Carnegie Institution of Washington, 1815), II: May 1, 1814 to December 31, 1819:159 - 61; W.C.C. Claiborne, "Claiborne to General Lambert," in The Letter Books of William C.C. Claiborne, 1801 - 1816, vol. 6, ed. Dunbar Rowland (Jackson, MS: Mississippi State Library and Archive, 1917), 6:352 - 53; W.C.C.

Claiborne, "Answer: Claiborne to General Lambert," in The Letter Books of William C.C. Claiborne, 1801 - 1816, vol. 6, ed. Dunbar Rowland (Jackson, MS: Mississippi State Library and Archive, 1917), 6:353 - 54; Kastor, The Nation's Crucible, 172. 
The negroes of the chain [chain gang] left at 6:30 for their work.

[P.S.] The negroes [arrested at $8 \mathrm{pm}$ ] were assembled in the house of Reinard Gailliard, in [group led by] a free negress Madelon. ${ }^{15}$

The Report of the Captain of the Guards, like all arrest records, indicates something explicit about policing. The City Guard functioned as first responders to disorderly and illegal activities. Over the previous night, the City Guard arrested: one slave at the behest of her master; seven slaves found gathering illegally; and, one slave who supposedly violated curfew. These records do not show a complete record of all crimes committed but, instead, emphasize that the police were applying legislation in ways they deemed fit. By arresting slaves found in groups, out on the streets, and not for violent or property crimes, the City Guard had become a truly preventative police force. They also incorporated legislation from the City Council to prevent the actions of slaves from becoming public order concerns.

A close reading of these records suggests strong similarities with the Reports of the Captain of the Guards in 1809. The arrests indicated that enslaved people were still a significant focal point for the New Orleans City Council and the New Orleans City Guard. However, these reports also indicated several new developments. The City Guard utilized new legislation to enter the property of slaveowners and arrest congregations of enslaved people. Masters also started to call upon the police force to arrest and punish their slaves. These types of actions would increasingly become the mark of the New Orleans City Guard. While military commanders, state executives, and

15. Louis Nicholas, "Rapport Du 11 Au 12 9bre 1814," Charles F. Heartman Collection 1724 - 1897 (Suite 319, Building 38, Xavier University of Louisiana, 1 Drexel Drive, New Orleans, LA 70125, 1814). 
the City Council established a number of practical means for New Orleans to deal with the actions of enslaved people, the responsibility for enforcing these regulations fell upon the New Orleans City Guard. Through enforcement, the New Orleans City Guard became a powerful source of authority within the city.

As with the above example, the daily reports of the Captain of the Guards in 1814 suggested that the misconduct of enslaved people remained a chief concern. Enslaved people made up $64 \%$ and $78 \%$ of the total arrests in 1809 and in $1814 .{ }^{16}$ These statistics suggest a combination of two forces. While enslaved people capitalized on the instability of the era, the City Guard responded by arresting the city's slaves at rates higher than their respective population. As Claiborne and Jackson discussed, the Battle of New Orleans posed a key moment for enslaved people to resist and run away. However, these slaves also committed numerous minor infractions of public order. Their actions ranged from running away and gathering illegally to improperly weighing traded goods. Judging by their arrests, the City Guard likely treated people of color as a suspicious class during the period and arrested slaves at a high rate to hem in minor infractions as well as major ones before they threatened New Orleans itself.

The Reports of the Captain of the Guards indicates that enslaved and free people generally committed the same types of crimes: public order, property and violent

16. Slaves made up between $35 \%$ and $27 \%$ of the total population of the city in those years. These statistics were built from a random sampling of the 663 total arrest records in 1814, from January to November. The random sample was created through an examination of 241 arrests or reaching a margin of error at 5.04\%. "Report of the Captain of the Guards"; "Report of the Captain of the Guards"; US Government, Census (1810), 82, 295; U.S. Census, Fourth Decennial Census, 81. 
crimes. ${ }^{17}$ The New Orleans City Guard arrested both enslaved people and free persons for crimes against public order at a greater rate than all other crimes. These arrests were followed by property crimes and violent crimes, respectively (See Table 6). ${ }^{18}$

Table 6: The sample of the Reports of the Captain of the Guards in 1814

\begin{tabular}{|l|r|r|r|r|}
\hline Crimes & $\begin{array}{l}\text { Slaves } \\
\text { Arrested }\end{array}$ & $75 \%$ & $\begin{array}{l}\text { Free } \\
\text { People }\end{array}$ & $25 \%$ \\
\hline Violent & 5 & $6 \%$ & 4 & $15 \%$ \\
\hline Property & 23 & $28 \%$ & 7 & $26 \%$ \\
\hline $\begin{array}{l}\text { Public } \\
\text { Order }\end{array}$ & 54 & $66 \%$ & 16 & $59 \%$ \\
\hline Total & 82 & & 27 & \\
\hline
\end{tabular}

Source: "Report of the Captain of the Guards." Charles F. Heartman Collection 1724 1897. Suite 319, Building 38, Xavier University of Louisiana, 1 Drexel Drive, New Orleans, LA 70125.

These arrest records highlight the fact that public order crimes were a high priority for the New Orleans City Guard. Marronage (running away) made up the largest percentage of public order arrests of enslaved people. Arrests of runaways also show the diversity amongst the enslaved people and their means of escape. Enslaved people used the woods

17. Of the 241 records in the sample, 101 entries referred to crimes and actions of people. The arrest records also contained a large number of reports of the chain gang leaving the police prison and different balls going on in the city that subtracted from the total number of crimes listed in the Reports of the Captain of the Guard. Of 101 people arrested, 110 crimes were committed. Slaves were responsible for 83 of the 110 crimes. "Report of the Captain of the Guards."

18. "Report of the Captain of the Guards," Charles F. Heartman Collection 1724 1897 (Suite 319, Building 38, Xavier University of Louisiana, 1 Drexel Drive, New Orleans, LA 70125, 1814). 
and the Mississippi River that surrounded the city to run away. ${ }^{19}$ They also stole or brought with them a number of provisions to aid their escape. ${ }^{20}$ The diverse stories of these arrests create a clearer picture of the different experiences of enslaved people running away and the supposed problems they created in society. While enslaved people ran away in a variety of ways and the type activity was not generally seen as a group crime, the context of the German Coast Rebellion and the War of 1812 suggested that the many individual cases running away could be more problematic to the system of slavery.

Other public order crimes also remained important in New Orleans. Enslaved people commonly committed other public order crimes as a temporary relief from their condition. The Report of the Captain of the Guards commonly related the arrests of enslaved people for various other crimes against public order, like disturbing the peace, sleeping outdoors, pris de boisson (drunkness), insolence, trying to hop a train, dancing; vagabondage; playing cards; forming an illegal society, and failure to complete service (See Table 6.A. in the Appendix for a complete list of arrests). ${ }^{21}$ Collectively, these

19. "Report of the Captain of the Guards," Rapport du 24 au 25 Janvier 1814, Charles F. Heartman Collection 1724 - 1897 (Suite 319, Building 38, Xavier University of Louisiana, 1 Drexel Drive, New Orleans, LA 70125, 1814).

20. "Report of the Captain of the Guards," Rapport de la Garde de L'Hotel de Ville Du 7 au 8 Novembre 1814, Charles F. Heartman Collection 1724 - 1897 (Suite 319, Building 38, Xavier University of Louisiana, 1 Drexel Drive, New Orleans, LA 70125, 1814).

21. "Report of the Captain of the Guards," Rapport du 29 au 30 Aout 1814, Charles F. Heartman Collection 1724 - 1897 (Suite 319, Building 38, Xavier University of Louisiana, 1 Drexel Drive, New Orleans, LA 70125, 1814); "Report of the Captain of the Guards," Rapport du 20 au 21 September 1814, Charles F. Heartman Collection 1724 - 1897 (Suite 319, Building 38, Xavier University of Louisiana, 1 Drexel Drive, New Orleans, LA 70125, 1814); "Report of the Captain of the Guards," Rapport de 18 au 19 
records suggested that the New Orleans City Council and the New Orleans City Guard acted in unison. Regulating and policing slavery became a means to preserve the public welfare of New Orleans.

These records also indicated that slaveowners were beginning to buy into the police authority. While the New Orleans City Council had made slaveowners the object of new legislation, not one was arrested for indiscretions against slaves or the public order. However, slaveowners did show up in another way. Masters requested the City Guard arrest their own slaves. In all of the arrests of enslaved people, $5 \%$ were made at the behest of their masters (See Table 7).

Table 7: Slaves Deposited by Masters 1814

\begin{tabular}{|c|c|c|c|c|c|}
\hline & & & & & Total \\
\hline & No & & Yes & & \\
\hline Slaves & 127 & $94.78 \%$ & 7 & $5.22 \%$ & 134 \\
\hline
\end{tabular}

Source: "Report of the Captain of the Guards." Charles F. Heartman Collection 1724 1897. Suite 319, Building 38, Xavier University of Louisiana, 1 Drexel Drive, New Orleans, LA 70125.

Enslaved people were not commonly arrested at the behest of their masters, but certain owners took an interest in using the police to control their enslaved people and support public order.

As the anxieties about enslaved peoples' actions dissipated at the end of War of 1812, the New Orleans City Council and the City Guard had a new approach to creating order in society: the municipality would take a greater role within policing slavery.

May 1814, Charles F. Heartman Collection 1724 - 1897 (Suite 319, Building 38, Xavier University of Louisiana, 1 Drexel Drive, New Orleans, LA 70125, 1814). 
While the City Guard was already an accepted part of New Orleans, they became a more integral factor in the city. Part of what the police did as they arrested slaves for public order crimes or accepted slaves from masters, was justify their presence. By surveilling and policing the city, the City Guard attempted to prevent smaller transgressions of public order from disrupting society or becoming larger disorders. These police practices continued to mark New Orleans in the years that followed.

\section{Conclusion}

Between 1811 and 1815, the theory and practice of policing revolved around slavery within New Orleans. Principally in response to the German Coast Rebellion and the War of 1812, the New Orleans City Council passed a number of ordinances that restricted the ways enslaved people lived, worked, and recreated, and thus, it expanded the mandate of the New Orleans City Guard. As a result, enslaved people remained a significant focus of policing. In the process, the New Orleans City Council and the City Guard began to assert the right to police masters as part of the greater good. The City Guard continued to arrest enslaved people most commonly for crimes of public order. As a result, New Orleans had new ways to arrest, surveil, and police its slave community. While municipal ordinances suggested that masters themselves became the object of policing, records indicate that the City Guard did not arrest masters. However, masters did increasingly use the City Guard to police their slaves. In the years that followed, authorities supported and expanded their prerogative to police slavery. 


\section{CHAPTER 4}

Salvador

$1835-1838$

\section{Introduction}

On February 11, 1835, O Diario de Pernambuco published an account of Salvador's Revolta dos Malês (January 24 - 25, 1835), originally from O Diario da Bahia. In the article, Francisco Gonçalves Martins, Bahian Police Chief (the highest ranking police official in the province) and juiz da paz in Salvador, detailed the two-day rebellion of some six hundred enslaved and free people of color. After reporting that order had been restored, Martins stated that the city would "have time for measures of the provincial legislature, arranged so that it is not necessary to fight a second time with such

people." "In the days and months that followed, provincial and câmara officials grappled with the proper ways to prevent such rebellions. In these efforts, enslaved people, free people of color, and masters became a focus of new leis (laws), posturas (municipal ordinances), éditos (edicts), and police reforms. These laws and their enforcement ushered in a new era for public order and urban slavery in Salvador.

As Salvador emerged from the Revolta dos Malês, it entered a distinct period of policing slavery. While international market prices for Bahian commodities fell, the city of Salvador continued to grow. Slaves remained a crucial part of the city. However, when enslaved people threatened society or disrupted its peace with their actions, it ran

1. Francisco Gonçalves Martins, "Interior, Bahia de Janeiro Da 1835 [Do Diario Da Bahia]," Diario de Pernambuco 8 (11 February 1835): 2 - 3. 
against official conceptions of public order. Bahian officials sought to deal with these possibilities through a number of police reforms and restrictive laws aimed at enslaved people and their masters. Salvador's police forces arrested enslaved people for a number of mostly public order crimes.

The chapter examines how provincial and municipal officials transformed the policing of slavery and thus adds another dimension to what we already know about Salavador between 1835 and 1838. Many historians have discussed the Revolta dos Malês in terms of enslaved people, free persons of color, and the slave trade. They have collectively argued that the rebellion transformed regional and national legislation. However, very few have examined the implementation of such laws. The chapter uses police records to argue that legal and institutional change marked the response to the Revolta dos Malês. ${ }^{2}$ Authorities established curfews and a pass system to control the actions of enslaved people. Legislation also made masters the object of surveillance: declaring martial law and the right to search houses; mandating masters teach their slaves Catholicism; and forcing all transaction of slaves to be registered. Legal changes both limited the authority of masters and made them more responsible for the actions of their slaves. Government authorities began to assume some of the responsibility of slave ownership. Yet, police forces were also part of the process. They continued to arrest enslaved people for public order crimes.

2. João José Reis, Slave Rebellion in Brazil: The Muslim Uprising of 1835 in Bahia, Arthur Brakel, Arthur Brakel (Baltimore, MD: John Hopkins University Press, 1993); Dale Torston Graden, From Slavery to Freedom in Brazil: Bahia, 1835 - 1900 (Albuquerque, NM: University of New Mexico Press, 2006). 
In addition to the rebellion, urban expansion influenced the policing of order in Salvador. Salvador continued to grow demographically and economically. As a major part of Salvador's labor force, enslaved people continued to play an important role in the city. Growth pressured local officials and their attempts to structure society. Local officials assumed the power to create legislation and institutions to promote order. In the name of public safety, officials began to surveil and police slaves and individuals who had associations to the population.

As part of official actions to reform public welfare, officials created new police groups. Provincial officials in Salvador were unhappy with the performance of the police during the Revolta dos Malês. They responded by establishing the Policia to patrol and police the city at a greater frequency than earlier groups. The Policia allowed provincial officials more direct oversight of Salvador's police system than in the years prior. The Policia and the Juizes da Paz enforced the laws passed in the wake of the Revolta dos Malês. As the Policia commonly arrested enslaved people for public order crimes, their actions made the police an important aspect of public welfare.

\section{The City}

The city of Salvador developed commercially and demographically from 1835 to 1838. While the growth rate of the tobacco and sugar industries slowed, trade in these commodities continued. At the same time, the population of Salvador rose. Development also created greater pressures on officials to police and order society.

Bahian sugar and tobacco economies began to falter by the 1830s. While the value of sugar and its production had risen in the years after the Haitian Revolution (1791 - 1804), prices stabilized and began to fall by the 1820 s. However, production patterns 
endured in Bahia. As the global production of sugar expanded into the 1820s, market prices fell. Bahian planters grew and exported greater amounts of sugar to retain their investments but profits decreased as prices fell. These economic currents spelled disaster for the Bahian sugar industry. ${ }^{3}$ A loss of markets, meanwhile, crippled Bahia's lowquality tobacco export economy after Brazilian Independence. While tobacco had been an important commodity, driving the Bahian export economy in the late colonial period, events in the 1820s and 1830s slowed the growth of tobacco. Bahian tobacco, primarily used for snuff and pipes, had been traded with European markets. It was also used in the African slave trade. European consumer preferences for higher quality cigar tobacco and the 1831 abolition of the slave trade severely restricted the commerce in lower-quality tobacco. With the collapse of these two markets for Bahian tobacco, trade in it faltered, only recovering in the late 1840 s when planters converted to the production of leaf tobacco necessary for cigars. ${ }^{4}$ While the economic decline of tobacco and sugar slowed Salvador's economy, trade patterns did not dictate population changes.

Despite economic issues, Salvador's population expanded. The population of Salvador rose between 1835 and 1838. Scholars have estimated there was a growth from 67,182 inhabitants in 1835 to 69,836 in $1838 .^{5}$ While expansion was not as substantial as the growth of New Orleans between 1804 and 1820, Salvador's population created

3. Mintz, Sweetness and Power, 73; Andrade, A Mão de Obra Escrava Em Salvador 1811 - 1860, 9; Barickman, Bahian Counterpoint, 33 - 41; Nishida, Slavery and Identity, 21.

4. Barickman, Bahian Counterpoint, 28 - 33.

5. Mattoso, Bahia, 138; Reis, Slave Rebellion in Brazil, 6. 
stresses on government officials interested in preserving order. Local government officials responded by becoming a proactive force in charge of ordering the larger numbers of people over time.

Collectively, commercial and demographic growth remained a challenge for provincial and municipal officials within Salvador. Maintaining public order endured an important imperative and the city's slave population lingered a point of emphasis. As local officials created legislation that constricted the lives of slaves and responded quickly to the Revolta dos Malês, they also established legislation to protect public order and policed minor disruptions to it.

\section{Slaves}

Enslaved people were an important part of Salvador and their actions had significant repercussions in the era. An illicit Atlantic slave trade and an internal slave trade affected Salvador, yet the population of enslaved people grew to highest percentage of the century during the 1830 s. Slaves continued to be a crucial part of the city's labor force. Their actions and, in particular, their part in the Revolta dos Malês prompted legislative and policing reforms.

In the years after the 1831 Abolition, two slave trades influenced the development of Salvador. First, an illicit Atlantic slave trade continued in Bahia. While the annual imported number of enslaved people fell, the trade did not cease. In the five years after the 1831 Abolition, the average annual import of enslaved people dropped from 4,740 
(from 1821 - 1825) and 9,580 (from 1826 - 1830) to 3,340 between 1831 and $1835 .^{6}$

Second, an internal slave trade in Brazil developed as the emerging mining and coffee production in regions outside of Bahia overtook sugar as Brazil's most important export. Within the transition, Brazil's Southeast—a region comprised of the provinces of Rio de Janeiro, São Paulo, Minas Gerais, and Espírito Santo—-became the new economic center of Brazil. ${ }^{7}$ Higher slave prices in other parts of Brazil created a new demand for enslaved people. Bahian slaveowners and slavetraders responded to higher slave prices by shipping their enslaved people to regions where they could obtain the highest profits for selling their enslaved people. While Bahian owners had always sold their enslaved people to other parts of Brazil, the traffic in enslaved people became more lucrative and accelerated in the years after the 1831 Abolition and again after the Revolta dos Malês. As masters sent enslaved people to other parts of Brazil, the slave population began to fall in comparison to the free population of Salvador. Population change did not mean that officials stopped concerning themselves with enslaved people and their impact on the development of the city. ${ }^{8}$

6. These estimates come from David Eltis. David Eltis, Economic Growth and the Ending of the Transatlantic Slave Trade (Oxford, UK: Oxford University Press, 1987), 243 - 45; Richard Graham, Feeding the City, 17.

7. Barickman, Bahian Counterpoint, 26 - 28.

8. Herbert S. Klein, “The Internal Slave Trade in Ninenteenth-Century Brazil: A Study of Slave Importations Into Rio de Janeiro in 1852," The Hispanic American Historical Review 51, no. 4 (November 1971): 567 - 85; Sidney Chaloub, Visões Da Liberdade: Uma História Das Últimas Décadas Da Escravidão Na Corte (São Paulo, SP: Companhia Das Letras, 1990), 56 - 60; Reis, Slave Rebellion in Brazil, 15; Richard Graham, "Nos Tumbeiros Mais Uma Vez? O Comércio Interprovincial de Escravos No 
While enslaved people made up around $42 \%$ of Salvador's total population in 1835 , they comprised $27.46 \%$ of Salvador's population by 1855 . Since we do not have intermediate censuses, it would be safe to assume that the decrease was in fact gradual. Scholars have suggested that the ratio of the slave population fell as a result of multiple factors, including the 1831 Abolition of the Atlantic slave trade, Brazil's internal slave trade, exportations as punishments for crimes, and slave emancipations. Scholars also have argued that the city began to transition from a "slave society" to a "slave-owning society," or from one dependent on slave labor to one in which enslaved people were not the predominant labor group. Nonetheless, slavery remained an important part of official constructions of order in Salvador, not least because of the actions of enslaved people affected the trajectory of policing and slavery both before and after the revolt. ${ }^{9}$

Controlling the slave population remained essential to conceptions of public welfare among officials and masters alike. As Salvador's percentage of slaves rose to its

Brasil," Afro-Ásia 27 (2002): 121 - 60; Graden, From Slavery to Freedom in Brazil, 133 38; Richard Graham, Feeding the City, 15 - 19.

9. Within the context of an estimated population increase of 3,592 people between 1835 and 1840, a simple growth of the free population and stagnation of slave population does not make up the population decrease of $3.65 \%$. Scholars have used the slave populations in 1835,1855 , and 1872 to make estimations of change. They have held that the population decreased between 1835 and 1855 at an estimated rate of .73\% per year. This suggests that masters most definitely sold and emancipated their slaves along with any possible natural changes in the general population of Salvador. Nascimento, Dez Freguesias Da Cidade Do Salvador, 97; Andrade, A Mão de Obra Escrava Em Salvador 1811 - 1860, 29 - 30; Chaloub, Visões Da Liberdade, 41 - 80; Reis, Slave Rebellion in Brazil, 6; Richard Graham, "Nos Tumbeiros Mais Uma Vez"; Nishida, Slavery and Identity, 1 - 26; Richard Graham, "Another Middle Passage? The Internal Slave Trade in Brazil," in The Chattel Principle: Internal Slave Trades in the Americas, ed. Walter Johnson (New Haven, CT: Yale University Press, 2004), 291 - 324. 
highest levels in the 1830s, local officials began to question the place of slaves in society. Government institutions regulated, surveilled, and policed the population of enslaved people. Yet, slaveowners conceptions of order initially rejected regulations and policing of their slaves. These masters rejected the imposition a slave pass system because it would impede the ability of Salvador's slaves to work and move throughout the city. ${ }^{10}$ However, the Revolta dos Malês changed these opinions and justified amendments to how authorities policed slavery.

\section{The Revolta dos Malês}

On Sunday January 25, 1835, Salvador was a buzz. During the previous night, two free women of color exposed a plotted slave rebellion. The Guarda Municipal Permanente and the National Guard preempted the revolt by arresting the main conspirators. Nonetheless, a number of enslaved people took to Salvador's streets, three to four hours prior to the planned rebellion. Throughout the morning, an estimated six hundred enslaved people and freemen initially attacked the jail where the police held the rebellion's leaders. When the police and military authorities repelled the initial onslaught, the rebels moved on to other military and government installations. As these offensives failed, the rebels fled to the northwestern part of the city. Within a few short hours, the local police and military units put the rebellion down. Seventy enslaved and free people of color died, but only nine persons who entered the rebels died during the

${ }^{10}$ Richard Graham, Feeding the City, 39. 
rebellion. ${ }^{11}$ In the immediate aftermath of the Revolta dos Malês, the citizens of Salvador "were still in a great state of alarm."."

In the months that followed, long-term reforms created a new era of policing slavery. While judicial officials only saw 288 cases specifically related to the slave rebellion, officials tried, executed, imprisoned, whipped, or deported seven hundred free and enslaved people of color. ${ }^{13}$ Salvador's judiciary tried and sentenced some 186 enslaved people and 102 free persons related to the revolt. After the rebellion had been broken and punishments had been doled out, the Revolta dos Malês continued to influence Salvador. It created two larger political trends. First, masters and officials were determined to suppress future rebellions. Second, the Revolta dos Malês gave pause to politicians who suggested reopening the Atlantic slave trade. These politicians made connections between newly-imported slave populations and the rebellion. They, therefore, assumed that banning the slave trade would be a good within society. At the same time, new conceptions of order emerged from the event. Bahian officials sought to control such slave rebellions principally through a number of ordinances that focused on

11. Padre Etienne Ignace Brazil, “A Revolta Dos Malês,” Revista Do Instituto Histórico e Geográfíco Da Bahia 72 (1909): 67 - 126; Reis, Slave Rebellion in Brazil, 170 - 230; Graden, From Slavery to Freedom in Brazil, 22 - 24.

12. Despatches from the United States Consuls in Pernambuco, 1817 - 1906 (Washington, DC: National Archives and Records Service, 1962).

13. Graden, From Slavery to Freedom in Brazil, 22 - 23. 
the slave community and those connected to it in the months and years that followed the Revolta dos Malês. ${ }^{14}$

\section{Legal and Police Reforms}

In the months and years after the Revolta dos Malês, Bahian officials sought to gain greater control over the communities implicated in the rebellion. While authorities arrested and punished individuals directly involved in the rebellion, legislators also passed a number of measures regulating how the community of people of African descent worked, lived, and recreated. The Bahian Legislative Assembly, presidents (positions akin to a governor within the United States), and police chiefs also passed a number of laws, edicts, and dispositions that increased the tools of surveillance on the slave community. Furthermore, these officials restructured Salvador's police forces. All of these reforms had the effect of reordering the relationship between government officials and enslaved people. Local authorities began to assume some of the responsibilities of slaveownership, as they surveilled and policed enslaved people and individuals connected to the slave population. ${ }^{15}$

On February 21, 1835, Francisco Gonçalves Martins - as the Chief of Police of Bahia — created one of the first long-lasting changes to the policing of slavery. Martins issued an edict mixing elements of a slave curfew and pass system. The Edict of February 21 (also referred to as the Edict of February 20) mandated that all enslaved

14. Graden, From Slavery to Freedom in Brazil, 24; Brown, "'On the Vanguard of Civilization'," 6; Reis, Slave Rebellion in Brazil, 223 - 30; Reis, Rebelião Escrava No Brasil, 548.

15. Martins, "Interior," 2 - 3. 
people on the streets of Salvador after $8 \mathrm{pm}$ have passes signed by their masters. Their passes had to indicate where slaves lived, where they were headed, and how long they were expected to be away. The law also required police forces to arrest all people of color, free or enslaved, found in public in groups of four or more. The police punished enslaved people with jail time and fifty lashes, nearly double the amount of lashes given for insulting the patrol, and charged their masters a fine that covered the cost of incarceration. Free persons implicated in these crimes faced punishments ranging from fines to jail time. ${ }^{16}$ The edict created new circumstances for enslaved people and slaveowners within the city of Salvador. While the city had long debated the use of passes, the edict was the first step towards the type of pass system found in other slaveholding societies. The Edict of February 21 was part of a move to create a stronger culture of surveilling of people of color than had operated in previous years. This edict required that police forces pay closer attention to people of color during nighttime hours and, especially when congregated in groups. In the process, the law shifted responsibility to masters for the actions of their slaves. Masters were now responsible for writing passes for their slaves. ${ }^{17}$

On March 28, 1835, the Assemblea Legislativa da Bahia (Legislative Assembly of Bahia) began to formulate its response to the Revolta dos Malês. As one of the first

16. Francisco Gonçalves Martins, "Edital Lavrado Pelo Chefe de Policia Da Bahia," in "Os Malês," Revista Do Instituto Historico e Geografico Brazileiro, no. 72 (1909): $125-26$.

17. Reis, Slave Rebellion in Brazil, 223; Graden, From Slavery to Freedom in Brazil, 23 - 24; Richard Graham, Feeding the City, 39. 
measures passed in the wake of the rebellion, they passed $L e i^{\circ} 1 . L e i^{\circ} 1$ suspended Article 179 Section 7 of Brazil's Constitução. Article 179 served as a Brazilian Bill of Rights, and section 7 held that "All citizens have in their house an inviolable asylum. At night no one can enter, except by the citizen's consent, except to defend against fire or flood; and during the day, [the house] may only be entered in cases, in accordance to the Law." Lei ${ }^{\circ} 1$ gave provincial judicial and police officials the right to enter households without inhabitant's permission at day or night. In essence, the provincial law was a specific subset of martial law that allowed government officials to search for enslaved and free people of color responsible for the revolt a few months earlier. The law had serious implications for slaveowners and free persons. Passage of such legislation suggested that slaveowners and freepersons had failed to control the slave population and still might be aiding or sheltering rebels, wittingly or not. Therefore, the provincial government claimed the right to search all properties for individuals, who might have been connected to the Revolta dos Malês. With Lei ${ }^{\circ} 1$ and others, officials altered the prerogatives of slaveownership. A concern for public safety became a mandate to reduce various forms of paternal authority over dependents and households. It now meant something different than the rights of slaveowners and householders. ${ }^{18}$

18. Brazil, Collecção Da Leis Do Imperio Do Brazil, Vol 1. Leis das Cortes Geraes Extraordinarias e Constituintes Da Portugueza (Rio de Janeiro, RJ: Imprensa Nacional, 1822), 32 - 35; Martins, "Interior," 2 - 3; Bahia, "N. 1. Lei de 28 de Março de 1835," in Collecção Da Leis e Resoluções Da Assemblea Legislativa Da Bahia, Sanccionadas e Publicadas Nos Annos de 1835 a 1838., Vol 1. (Salvador, BA: Typ. Constitutional de França Guerra, 1863). 
The Bahian Legislative Assembly also sought to create stronger institutions to police slavery. Upset by the performance of the Guarda Nacional and Guarda Municipal Permanente and their inability to prevent the Revolta dos Malês, the provincial assembly disbanded the regional Guarda Municipal Permanente. The assembly established a new police force, simply entitled the Policia. The new force reported directly to the police chief and president of the province. The Policia served as an intermediary between municipal officials and provincial administrators. While their primary responsibility remained within Brazil's interior, the paramilitary Policia patrolled the streets of Salvador to arrest people who were in the act of committing of crimes. Like previous police groups, the Policia became responsible for patrolling the streets, arresting persons during the commission of a crime, and supporting the local judiciary. For the remainder of $L e i^{\circ} 1$, the Policia helped judicial and military officials track down rebels. The Policia also enforced many of the regional laws that came in the wake of the Revolta dos Malês. At the same time, they remained an alternative to the civilian police system comprised of the provincial police chief, the juiz da paz, delegados (delegates or deputies) and subdelegados (precinct heads). The system of delegados and subdelegados also patrolled and reported written accounts of their actions. Yet, the Policia and justices of the peace created a strong police presence within Salvador. ${ }^{19}$

On May 13, 1835, the provincial legislature passed a law focused on enslaved and free people of African descent by setting up processes for surveilling and policing free

19. Etienne Ignace Brazil, “A Revolta Dos Malês,” Revista Do Instituto Geográfico e Histórico Da Bahia, no. 33 (1907): 149; Brown, “"On the Vanguard of Civilization'," 64. 
people of color. Legislators also instituted a series of taxes placed on the free African community in the province. Finally, it included provisions directly aimed at enslaved people and their masters. $L e i^{\circ} 9$ set up a procedure for the surveillance of the province's population of people of African descent. Articles ten through fourteen established that the Juizes da Paz were required to keep a roll of all free and enslaved people of color in their district, indicating their names, nationality, age, place of residence, and occupation. It also indicated who was to collect information for the roll, set up procedures for keeping track of Africans entering and exiting the province, and laid out the distribution of funds for those involved in taking the roll. ${ }^{20}$ Aimed generally at the free people of color community, Lei ${ }^{\circ} 9$ created both a complex tax system and a mandate to watch over enslaved and free people of color. The piece of legislation also created a directive for masters to convert all enslaved people from their African religions to Catholicism. The article stated that all enslaved people were to be "instructed in the mysteries of the Christian Religion and baptize[d]." Masters would be fined 50\$000 (or roughly $25 \$$ ) for not doing so within six months of the publication of the law. ${ }^{21}$ Officials established a new era of oversight of people of color, who became the objects of surveillance with Lei ๑9. At the same time, the Christianization attempted to dissuade foreign religion,

20. Bahia, "N. 9. Lei de 13 de Maio de 1835," in Colleç̧ão Da Leis e Resoluções Da Assemblea Legislativa Da Bahia, Sanccionadas e Publicadas Nos Annos de 1835 a 1838., Vol 1. (Salvador, BA: Typ. Constitutional de França Guerra, 1863), 24 - 25.

21. Bahia, “N. 9. Lei de 13 de Maio de 1835," 26. 
languages, and practices, particularly Arabic. In the process, authorities sought to break down the communication and cooperation that enabled the Revolta dos Malês. ${ }^{22}$

On June 2, Bahia’s Assemblea Legislativa passed Lei ${ }^{\circ} 14$. Lei ${ }^{\circ} 14$ more directly focused on slave labor within Salvador. With the law, provincial officials took aim at the canto labor system. Lei ${ }^{\circ} 14$ sought to control these cantos by placing them within the direct oversight of provincial authorities. Captães do canto (captains of the canto), who traditionally had been from the same African ethnic group as the workers in their respective canto, worked as their main administrator. In a canto, free persons of colors mixed with enslaved people to do various unskilled and semiskilled jobs throughout the city. Here, different workers performed a variety of jobs — carrying people and goods throughout the city, barbering, cooking, and marketselling. ${ }^{23}$ With Lei ${ }^{\circ} 14$, cantos became known as capatazias (overseerdoms) and the new position of capatases (foremen) replaced the captão do canto (captains of the canto) as the head official of the labor group. These capatases would be accountable for the conduct and good performance of members of the capatazias. The capatases also were responsible for creating a roll of the members of the capatazias, which included: member's names, where they lived, their districts, the names of their masters (if they were enslaved

22. Reis, Slave Rebellion in Brazil, 224 - 25; Reis, Slave Rebellion in Brazil, 224 25.

23. Africa and the Americas: Interconnections During the Slave Trade, ed. José C. Curto and Reneé Soulodre-La France (Trenton, NJ: Africa World Press, 2005), 280. 
people), and the types of jobs they performed. ${ }^{24}$ A year after its passage, new legislation restructured capatazias, instituting an inspector to oversee all capatases. ${ }^{25}$ These laws had profound effects on enslaved people and their labor within the city. While the rolls essentially became a census for tax purposes, Lei ${ }^{\circ} 14$ created provincial oversight of the labor of enslaved people. Although these records had little use in the everyday interactions of authorities and enslaved people, it was a form of long-term surveillance. In this way, Lei ${ }^{\circ} 14$ not only made enslaved people more responsible to government authorities but created a way to follow changes within their labor and living patterns. ${ }^{26}$

Collectively, these laws passed in the wake of the Revolta dos Malês became the first steps in creating a new system of public order that focused on surveilling enslaved and free people of color. The Revolta dos Malês invoked concerns about public safety for officials and masters. As a result, government officials in Salvador new laws and institutions to protect public welfare that mainly revolved around oversight. Legislators, the Policia, and the Juizes da Paz became accepted part of slavery in Salvador.

24. Bahia, "N. 14. Lei de 2 de Junho de 1835," in Collecção Da Leis e Resoluções Da Assemblea Legislativa Da Bahia, Sanccionadas e Publicadas Nos Annos de 1835 a 1838., Vol 1. (Salvador, BA: Typ. Constitutional de França Guerra, 1863), 38 - 39; Reis, Slave Rebellion in Brazil, 227 - 28.

25. Bahia, "Regulamento para a Formação de Capatasias, Em Formidade Da Lei d'Assembléa Legislativa Provincial de 2 de Junho Do Anno Passado, Sob n. 14," in Collecção Da Leis e Resoluções Da Assemblea Legislativa Da Bahia, Sanccionadas e Publicadas Nos Annos de 1835 a 1838., Vol 1. (Salvador, BA: Typ. Constitutional de França Guerra, 1863), 40 - 44.

26. Reis, Slave Rebellion in Brazil, 227 - 28. 


\section{Policing Slavery in Practice}

On March 14, 1837, Commandant General Manoel Coelho de Almadea Sande sent a report of the actions from the Policia, the provincial military police, to the president of Bahia. In the report, Sande noted:

Africans[,] Benedicto and Julião[,] were arrested for the Edict of the 20 of February 1835; and the Juiz da Paz of the Second District in the fregusia of São Pedro, the cabra [person with skin between black and brown color] Felisberto, and a crioulo [a black person born in Brazil] Marcos Ferriera for disorder, who appear to have a compass; in the first district of Curato da Sé, Paulino Hernandes Anjos, delivered to the Inspector of the District; and the preta (black person) Maria Luiza for running away on the order of the [official of the] district, Manoel Joze Lidade. ${ }^{27}$

The Parte Geral Da Guarda Policial on March 14, 1837 indicated something specific about the legislation that the Policia enforced. The report accounted the four total actions taken by the Policia on that day. These records indicated that the Policia greatly differed from the Juiz da Paz. While the records of the Policia were more specific about the arrests and the commission of crimes, they also related the hierarchy of policing. The Policia arrested individuals and delivered them to other officials. However, unlike the records of the Juiz da Paz, the records of the Policia do not contain information about punishments for crimes. The Policia were first responders, and their accounts relied on physical descriptions rather than attempts to ascertain the status of individuals. As the differences between enslaved and free people of color were not always clear, it makes reading these documents difficult. Yet, certain categories of crimes applied to the general population, while others applied specifically to people of color or slaves.

27. "Parte Geral Da Guarda Policial, Quartel Em S Bento 14 de Março de 1837," Mapas Diários, Maço 6301, Correspondencia recebida da Guarda Policial (1832 - 1839) (Salvador, BR: Arquivo Público do Estado da Bahia, 1837). 
The records of the Policia relate several important things. First, the report by Commandant General Sande differed greatly from the reports in 1831 by Juiz da Paz Suixaz. These records contain more accounts of arrests than in the 1831 report of Juiz da Paz Suixaz. Second, these nightly reports provide the best insight into official police actions because of the detailed nature of the records. While the Policia were just one of police groups, their actions suggest that policing slavery was an important aspect of maintaining public welfare. ${ }^{28}$

Police authority remained central to Salvador in the years after the Revolta dos Malês. The Parte Geral da Guarda Policial (Daily Police Reports) taken at the Quartel em São Bento written by Commandante Geral Manuel Coelho do Almenda Sande provides great insight on the state of Salvador's law enforcement in the years after the Revolta dos Malês. The daily reports related many kinds of information: who reported for duty; who was arrested during the rounds of the police; who was apprehended by the juiz da paz; any problems with the streetlighting system; and the Policia patrolmen on duty the following day. While these reports detailed the various actions of the police, arrest records were often not that descriptive about the people being arrested, particularly in comparison to those in New Orleans. Arrest records only listed people's name, race, status or ethnicity, the crime they were accused of committing, and occasionally the district where they were arrested. Even so, when combined and looked at holistically, these sources provide insight both into the state of law enforcement and its relationship to slavery in the time between 1835 and 1838.

28. Brown, “'On the Vanguard of Civilization'," $62-75$. 
In the context of the larger economic, demographic, and legal framework of slavery in Salvador, policing its city streets remained an important way for local and municipal authorities to impose order. The Parte Geral da Guarda Policial (Daily Police Reports) provided an important ruler for measuring the overall changes in law enforcement. While these records most closely related the actions of the provincial Policia within Salvador, they also served as a barometer of the practices and theories that guided public order. A number of provincial laws had made people of African descent the focus of local officials and had a profound impact on constructions of order in the city. However, it did not necessarily mean a change in the way officials in Salvador policed slavery. Salvador's police, the Policia and Delegados, arrested enslaved people for a number of crimes. Yet, the records indicated that the Policia did not simply enforce provincial legislation.

Amongst these records, two main trends become clear. ${ }^{29}$ First, Salvador's police arrested enslaved people at a much lower rate than their representative percentage of the population within the city. Enslaved people accounted for roughly $14 \%$ of total arrests in

29.The general statistics from the Parte Geral in 1837 comes from a random sampling of the 1088 police actions that took place from January to November 6 . Of the 1088 recorded actions, I examined a random sample of 277 documents. Of the 277 , the police listed the slave, racial, or ethnic status and the crimes accused of 243 individuals. These 243 individuals committed 282 crimes, meaning each the police arrested each individual for an average of 1.6 crimes. "Parte Geral Da Guarda Policial," Mapas Diários, Maço 3059, Maço 6301, Guarda Urbana, Correspondencia recebida da Guarda Policial (1832 - 1839) (Salvador, BR: Arquivo Público do Estado da Bahia, 1837). 
1837. ${ }^{30}$ Yet, enslaved people made up between $42 \%$ and $28 \%$ of the city's population from 1834 to $1855 .{ }^{31}$ These differences suggest that enslaved people were not the sole focus of policing in the years after the Revolta dos Malês. Legislation on public order suggested greater surveillance and policing of the actions of the enslaved population. ${ }^{32}$

Second, the most common causes of arrests—amongst enslaved people and free and freed people alike - were crimes against public order. The police arrested enslaved people for these crimes at a similar rate to the entire population (See Table 8). ${ }^{33}$

Table 8: Total Arrests reported at São Bento [January - November 6, 1837]

\begin{tabular}{|l|c|c|c|c|}
\hline Crimes & $\begin{array}{c}\text { Slaves } \\
\text { Arrested }\end{array}$ & $13 \%$ & $\begin{array}{c}\text { Free } \\
\text { People } \\
\text { Arrested }\end{array}$ & $87 \%$ \\
\hline Violent & 3 & $8 \%$ & 19 & $8 \%$ \\
\hline Property & 1 & $3 \%$ & 14 & $6 \%$ \\
\hline $\begin{array}{l}\text { Public } \\
\text { Order }\end{array}$ & 33 & $89 \%$ & 212 & $87 \%$ \\
\hline Total & 37 & & 245 & \\
\hline
\end{tabular}

Source: "Parte Geral Da Guarda Policial.” Mapas Diários. Maço 3059, Maço 6301. Guarda Urbana, Correspondencia recebida da Guarda Policial (1832 - 1839). Salvador, BR: Arquivo Público do Estado da Bahia.

30. Of the random sample of 282 documented crimes, Manuel Coelho do Almenda Sande listed slaves responsible for committing 37 crimes. "Parte Geral Da Guarda Policial."

31. Mattoso, Bahia, 138; Reis, Slave Rebellion in Brazil, 6.

32. Reis, Slave Rebellion in Brazil, 6.

33. While public order crimes made up $86.53 \%$ of accused crimes of non-slaves, it made up $89.19 \%$ of slave arrests. Collectively, the entire population was arrested for these types of crimes $86.88 \%$ of the time. "Parte Geral Da Guarda Policial." 
Broadly defined, these crimes refer to ones less harmful to property or individuals and more representative of social disorder. The police arrested free persons for violating the Edict of February 20 (a curfew established for enslaved people and blacks), running away, drunkenness, vagabondage, being found out late, playing illegal games, desertion, rioting, illegally selling arms to enslaved people, batuque (drumming or loud noises, often attributed to people of color), idleness, or sleeping out of doors (See Table 8.A. in the Appendix for a complete list of arrests). However, unlike their free counterparts, enslaved people were most commonly arrested for infractions of prescribed and proscribed conceptions of public space and public morals for enslaved people, including disorder, suspicion, vagabondage, being found out late, and running away. As the Policia arrested enslaved people for crimes aside from running away and rebellion, it refined constructions of public order to include crimes that disrupted peace.

Amongst the arrest records of enslaved people, a few clear patterns emerge. First, enslaved people were most frequently arrested for running away. In Salvador-as in New Orleans and other slaveholding cities throughout the Atlantic—police commonly arrested individuals as runaways. Fifty-seven percent of all arrests of enslaved people in Salvador in 1837 were for running away. ${ }^{34}$ These records further highlight how enslaved people fled from a variety of places-from local freguisias or distant parts of Brazil. ${ }^{35}$

\section{4. "Parte Geral Da Guarda Policial."}

35. "Parte Geral Da Guarda Policial, Quartel Em S Bento 6 de Junho de 1837," Mapas Diários, Maço 6301, Correspondencia recebida da Guarda Policial (1832 - 1839) (Salvador, BR: Arquivo Público do Estado da Bahia, 1837); "Parte Geral Da Guarda Policial, Quartel Em S Bento 16 de Julho de 1837,” Mapas Diários, Maço 3059, Guarda Urbana (Salvador, BR: Arquivo Público do Estado da Bahia, 1837). 
Collectively, the records of the Policia indicate that the police did arrest enslaved people in the years after the Revolta dos Malês. However, enslaved people were not the exclusive focus of police officials. Enslaved people, in fact, made up only a minor percentage of the arrests in the city. While provincial bureaucrats may have passed laws that drastically changed slavery and mastery, the Policia reaffirmed policing practices of earlier police institutions. The Policia promoted order through policing the entirety of Salvador. Nonetheless, enslaved people still came before the police and remained important to their conceptions of public order. Collectively, laws and their enforcement highlight the fact that local police officials were given a variety of tools to control the slave population. The Policia responded to the actions of legislators and enslaved people to become an accepted part of everyday life in Salvador.

\section{Conclusion}

Clearly, the late 1830s were a period of great change in Salvador, particularly in the ways that the city policed slavery. The Revolta dos Malês forced a swift reaction from provincial officials. The police chief and legislative assembly passed a number of edicts and laws that restricted the actions of both enslaved people and their masters. Legislation limited the ways enslaved people lived, worked, and recreated, while contemporaneously making masters more responsible for their enslaved people. The legislation was intended to make the slave population more visible and to allow for stricter surveillance than in previous eras. Legislative changes theoretically allowed the Bahian provincial government to assume some of the responsibilities of slave ownership. Yet, it did not translate to a stronger emphasis on policing slavery. Slaves remained essential to constructions of public order and became a justification for policing those 
connected to enslaved people. Policing slavery continued within the pattern in Salvador until the early 1840 s, when centralization and nationalism transformed the administrative landscape of the country. The political movement, called the Regresso, initiated a number of reforms that transformed the policing of slavery to a more bureaucratic and surveillance form in the years that followed. 


\section{PART III}

Police Forces and the Policing of the Community

In the third period -1815 to 1835 in New Orleans and 1838 to 1850 in

Salvador - the threat of rebellion and war had subsided in each city; however, officials continued to police order through the slave community and those related to it. Although the percentage of slaves decreased in each city during the time period, enslaved people remained a focal point of local legislators and the police. The New Orleans City Council, the Bahian Legislative Assembly, and Salvador's câmara established laws that created a strong culture of surveillance and prevention. Police used these laws to continue to arrest enslaved people for public order crimes. 


\title{
CHAPTER 5
}

\author{
New Orleans
}

1815 to 1836

\section{Introduction}

On March 24, 1830, L’Abeille-a newspaper in New Orleans catering to its

Creole population - published an account of events taking place the previous day on the

outskirts of the city. The article stated:

Yesterday afternoon about 4 o'clock, an application was made to the city guard by the owner of a runaway negro, to have him arrested, having discovered where he was. The officer of the guard enquired whether it was necessary to send two men, and was answered that the negro was very submissive, and that one man would be enough to conduct him [.] not withstanding, the officer ordered two of the guards to go with the owner, and they went on the Bayou road where they found the negro in a hut belonging to Mr. Milns. As he was almost naked, his master ordered him to put on his clothes and to follow him. The negro feigned to obey and pretended to look for his coat[.] when all at once he rushed on one of the guards, wrung his sword out of his hands, and at the same moment applied a severe blow with it on the head of the other guard, which cut his hat, and with another blow severely wounded him in the wrist. The master of the negro irritated at the daring impudence fired two pistols at him and wounded him in the arm; another person who was present fired a third pistol but missed him. The negro then seized an ax, and breaking down some planks, escaped through the garden. A hunter who happened to be there at the moment fired at the request of the master his two loads at the negro, which hit him in the back and the thigh and brought him down: it was only then that he could be mastered.

How many such occurrences will it required to corroborate the opinion which we expressed a few days ago, and to convince those who pretend that the city guard ought on no occasion to make use of their arms? We do not wish to influence the opinion of any one, but it seems to us that the last occurrence will be sufficient to enlighten those who will be called upon to decide on the fate of the city guard, who is to be brought in a few days before the criminal Court for having killed a sailor. ${ }^{1}$

While the author used the anecdote to justify the use of force, the article laid bare the

close relationship between the City Guard, masters, and enslaved people as it developed

1. "Application; Negro; Enquired; Necessary; Submissive; Bayon; Mr. Milns; Enough,” L'Abeille, 24 March 1830, 5. 
by the 1830s. Within the eyes of officials in New Orleans, order remained precarious after 1815 . While runaway slaves could appear submissive, they had the capacity to cause damage, injury, or death. The author suggested masters and the City Guard remain vigilant. They also relied on one another. While masters routinely called the City Guard to help collect their slaves, control of enslaved people also depended on the general public (the hunter). By extrapolation, public welfare hinged upon the help of the community, not on the laws and the guardsmen alone.

At the same time, the article also illustrates a tension between the slaveowners and the police. The police asked the owner how many men to send, and then did not follow his recommendation. The event itself justified a police response; the slave was indeed dangerous and injured one guard. The article also suggests the culpability of the master for both letting the slave run away and misjudging his violence. Public welfare required the participation of all individuals in New Orleans; however, police authority was the central force controlling disorder within the community.

While the account reflected the disorder posed by enslaved people who ran away, acted out, and rebelled, it also highlighted a new form of policing slavery that also focused on the public surrounding the slave population. In the years after 1815 , the New Orleans City Council broadened their definition of "persons disturbing public tranquility" to include the multitude of working-class individuals coming to Louisiana. ${ }^{2}$ These

2. New Orleans, Ordinances Issued by the City Council of New-Orleans, 66 - 68; "An Ordinance containing several provisions, for the City of New Orleans" in New Orleans, Ordinances Ordained and Established by the Mayor \& City Council of the City of New Orleans (New Orleans, LA: J.C. de St. Romes, 1817), 6. 
groups - predominantly of Irish and German ancestry — would eventually edge enslaved people out of the urban labor market and the city's arrest records. However, particularly before the 1840s, enslaved people remained an important part of official conceptions of order. Moreover, after that point, "disorderly" people in New Orleans would be policed according to laws and institutional practices first developed in the regulation of enslaved people.

New Orleans experienced an era of demographic, economic, and political developments in the years after 1815 . The city grew as a commercial and demographic center of the United States. New Orleans also slowly politically incorporated into the United States. At the same time, legislators and the police sought to control the slave population by making masters more legally culpable for the actions of their enslaved people. The New Orleans City Council and the City Guard inserted themselves into the fabric of New Orleans by surveilling and policing enslaved and free people of color and masters. By the late 1830s, policing slavery within New Orleans became much like that of other Atlantic slaveholding cities. While specific laws were unique to each urban environment, a common thread of official oversight and a significant police presence ran throughout them.

The 1820s and 1830s were full of bureaucratic reforms aimed at ordering slavery. Understanding slavery as an issue of public welfare, officials passed a number of ordinances traditionally regulating the ways in which enslaved people worked and recreated. These laws prohibited trading with slaves, broke up slave gatherings, established punishments for loud noises and insolence, governed slaves working on ships, and created a registry of slaves' laboring in the city. Legislators constructed an 
encompassing system of prevention and surveillance. The New Orleans City Council also made masters more accountable for their slaves through legislative measures. Masters, too, relied upon the police to take up, punish, and employ troublesome enslaved people. These theories and practices guided the policing of slavery until the New Orleans City Council demilitarized the City Guard in 1836.

Within the scholarship on New Orleans, historians have described the 1820s as a middle period between Creole and American rule. While Creoles retained much of their political clout in the previous era, Americans began to take a more prominent role in Louisiana. ${ }^{3}$ Within New Orleans, a white elite political system took shape, accommodating both Creoles and Americans. ${ }^{4}$ The coexistence would eventually draw to a close in 1836, when Louisiana subdivided New Orleans into several districts and fractured the power Creoles held within municipal government. ${ }^{5}$ To illustrate the transition, scholars have often traced the political debates revolving around slavery within state government. Their works have generally focused on the difference between French, Spanish, and American slave law and the restrictions Louisianans placed on emancipation. These historians pointed to the regulation of free black immigration, the expulsion of those emancipated, and the condemnation of inter-racial relationships in an

3. Dargo, Jefferson's Louisiana; Crété, Daily Life in Louisiana, 1815 - 1830, 36 56; Hanger, Bounded Lives, Free Black Society, 163 - 70; Din, Spaniards, Planters, and Slaves, 220 - 36; Ingersoll, Mammon and Manon in Early New Orleans, 315 - 48; Spear, Race, Sex, and Social Order in Early New Orleans, 179 - 214.

4. Kastor, The Nation's Crucible, 228.

5. Wegmann, "No Ordinary, No Earthly Scene," 34. 
1830 Louisiana law as the destruction of French and Spanish slave practices. ${ }^{6}$ The chapter qualifies that argument and demonstrates the complexity of the era. It was not simply a generational displacement of Creoles that led to changes within New Orleans slave society. The chapter's focus on police bureaucracy and arrests brings into relief the actions and goals of public officials, enslaved people, and masters.

While many historians have discussed the legal and political changes within New Orleans and Louisiana and their effects on the trajectory of slavery, few have made connections to the enforcement of such legislation. The chapter argues that law enforcement also played an integral part in shaping urban slavery. The City Guard arrested people for public order concerns to protect public welfare. While authorities still feared runaway and rebellious slaves, policing focused on a number of minor nuisances amongst the slave community. By creating legislation for the control on loud noises, hiring out, insolence, and slaves working on ships, officials sought to both preempt rebellious and runaway slaves and protect public morals. ${ }^{7}$

\section{The City and the Adams-Onis Treaty}

By 1838 , New Orleans had grown, so much so that a publisher of a city directory in that year declared:

6. Hanger, Bounded Lives, Free Black Society, 163 - 70; Schafer, Becoming Free, Remaining Free, 1 - 12; Spear, Race, Sex, and Social Order in Early New Orleans, 179 215.

7. Schafer, Slavery, The Civil Law, and the Supreme Court of Louisiana; Rousey, Policing the Southern City; Ingersoll, Mammon and Manon in Early New Orleans; Schafer, Becoming Free, Remaining Free; Kastor, The Nation's Crucible; Spear, Race, Sex, and Social Order in Early New Orleans; Scott, "Paper Thin." 
New Orleans has been rated the third city of the Union; but she is in reality the third only in population, and second in a commercial point of view. Her imports are now exceeded only by New York and Boston; while her exports are nearly triple any port in the United States except New York, which she exceeds by one third. ${ }^{8}$

The trade and size of the city by the late 1830 s stood as a culmination of many historical patterns. As the principal commercial hub of trade west of the Appalachian Mountain range, New Orleans expanded economically and physically as Americans moved westward. Booming trade cotton and sugar also ensured the demographic growth of New Orleans. Expansion shifted the balance of political powers within New Orleans and Louisiana, as Americans and immigrants began to outnumber Creoles. Consequently, officials grappled with ordering New Orleans during this era. ${ }^{9}$

The commercial growth of Louisiana and, by extension, New Orleans was immense after 1815 . While 65,000 bales of cotton, 20,000 hogsheads of sugar, 1,000,000 gallons of molasses, and 400,000 gallons of tafia arrived on the docks of New Orleans in 1817. ${ }^{10}$ These numbers had risen by 1838. In that year, New Orleans exported 21,338 hogsheads and 2,969 barrels of sugar. Sugar producers within the United States, unlike Brazil, continued to reap the profits from their commerce because of heavy protective tariffs. ${ }^{11}$ However, sugar was not the only cash crop. Commerce in cotton also defined

8. J. Gibson, Gibson's Guide and Directory of the State of Louisiana, and the Cities of New Orleans and Lafayette (New Orleans, LA: J. Gibson, 1838), i.

9. Spear, Race, Sex, and Social Order in Early New Orleans; Dessens, Creole City.

10. Paxton, The New-Orleans Directory, 29 - 31.

11. Gibson, Gibson's Guide and Directory, 287; Richard Follett, The Sugar Masters: Planters and Slaves in Louisiana's Cane World, 1820 - 1860 (Baton Rouge, 
the city. In 1838, twice as many bales of cotton remained in stockpile as were shipped through the port in 1817. Out of the 567,355 bales of cotton that arrived in New Orleans, merchants exported 459,534 bales and retained 126,123 bales for their stockpile. ${ }^{12}$ While New Orleans exported twelve million dollars' worth of commodities annually in 1820 , the commerce reached fifteen million dollars by 1830 , a healthy $25 \%$ growth over a decade. ${ }^{13}$ By 1838 , the port of New Orleans imported fifteen million and exported thirtyseven million dollars' worth of commodities, bringing twenty-two million dollars' worth of profit to the city and its merchants. ${ }^{14}$

Commercial and economic growth advanced with demographic expansion. It created opportunities for individuals of all classes within New Orleans. In the twenty years between 1820 and 1840 , the city grew by roughly 70,000 people. New Orleans reached 102,160 inhabitants by 1840 . Demographic growth made New Orleans one of the largest cities in the United States by the $1840 \mathrm{~s} .{ }^{15}$

LA: Louisiana State University Press, 2005), 20 - 21; Adam Rothman, Slave Country: American Expansion and the Origins of the Deep South (Cambridge, MA: Harvard University Press, 2005), 178 - 79.

12. Walter Johnson, River of Dark Dreams: Slavery and Empire in the Cotton Kingdom (Cambridge, MA: The Belknap Press of Harvard University Press, 2013), 256; Gibson, Gibson's Guide and Directory, 287.

13. Paxton, The New-Orleans Directory, 27; Gibson, Gibson's Guide and Directory, 286.

14. Gibson, Gibson’s Guide and Directory, 286.

15. U.S. Census, Fourth Decennial Census, 81; U.S. Census, Fifth Decennial Census (Washington, D.C.: Duff Green, 1831), 104 - 05; U.S. Census, Sixth Decennial Census (Washington, D.C.: Duff Green, 1841), 60 - 63, 234 - 39, 256. 
Diplomatic and political events also shaped Louisiana and New Orleans after 1815. In 1819, John Quincy Adams and Luis de Onís led negotiations between the United States of America and Spain, respectively. In the sixteen-point Treaty of Amity, Settlement, and Limits Between the United States of America and the King of Spain, Adams and Onís laid the groundwork for the American acquisition of East and West Florida and established a border between the United States and Spanish Texas at the Sabine and Red Rivers, effectively giving Louisiana its modern geographical shape. The Adams-Onis Treaty also highlighted something in terms of orderly relations with slaves. The treaty put Americans and Spanish in the area on friendly terms and effectively shut the border between Louisiana and Texas to runaway slaves. While an uncertain number of slaves still escaped, it no longer became practice for Spanish governors to encourage runaways. The treaty reinforced the political stability of statehood and strengthened the political outlook for Louisiana. ${ }^{16}$

While New Orleans continued to grow, the next major political change occurred in New Orleans in 1836, as Louisiana broke down New Orleans into three different municipalities. The splitting of the city along the lines of the Vieux Carré, Faubourg Marigny, and Faubourg Saint Marie marked a major political development. While the political divide between Creoles and Americans continued to define New Orleans throughout the early nineteenth century, the division of the city effectively marked the splitting up of Creole control. New political arrangements left Creoles in power in the

16. Public Lands, vol. V of American State Papers (Washington D.C.: Gales \& Seaton, 1860); Kastor, The Nation's Crucible, 204 - 05. 
Vieux Carré but subject to the input of Americans in the other municipalities. Creoles continued to lose their political power within Louisiana in the years that followed. ${ }^{17}$

Expansion and political realignments in the city marked an important transition in the administration of order and slavery. The economic and demographic growth created a larger task for preserving order in New Orleans. With more inhabitants and more monies than in the previous eras, preserving order remained important but it took a greater government presence. Yet, enslaved people continued to be an important aspect of official concerns for public order. They remained a part of the city, its growth, and its political developments. The New Orleans City Council and the City Guard created new ways to oversee New Orleans' slave population.

\section{Slaves}

The slave population also played an important part in the growth of New Orleans. Enslaved people made up a significant proportion of the population until the 1840s. As slaves lived, worked, and played in the city, their actions influenced discussions of order and stability in New Orleans. While slaves continued to runaway and rebel, government officials began to regulate and police minor crimes committed by enslaved people in the city.

Slavery first expanded and then contracted within New Orleans between 1820 and 1850. While the slave population grew from $27 \%$ to $31 \%$ of the total population of New Orleans between 1820 and 1830 , this population had decreased to $15 \%$ (of 18,068 ) by

17. Schafer, Becoming Free, Remaining Free, 7; Wegmann, "No Ordinary, No Earthly Scene," 34; Dessens, Creole City, 208 - 11. 
1850. These changes made enslaved people much less commonplace by the $1850 \mathrm{~s} .{ }^{18}$ While scholars have debated whether inhospitable conditions for enslaved people within cities or high slave prices in agriculture labor fueled these demographic changes, the one thing that is clear is that they did have real ramifications on the policing of slavery in New Orleans. ${ }^{19}$

Official concerns for public welfare continued to move beyond the slave population. Enslaved people remained within New Orleans; however, the throngs of working-class individuals who came to the city also became a concern. Contemporaries had already identified these working-class individuals in their relationship to slaves as a problem as they came together in the city's taverns, cabarets, and gambling houses. However, the ways officials policed slavery served as a model for engaging these working-class individuals. $^{20}$

Collectively, the growth of New Orleans and the changing role of enslaved people created new stresses on society. The New Orleans City Council responded with ordinances that created new forms of policing order. Legislators instituted ordinances focused on the various aspects of enslaved peoples' lives. At the same time, the New Orleans City Guard interpreted and applied these laws to surveil and police slaves.

18. U.S. Census, Fourth Decennial Census, 81; U.S. Census, Fifth Decennial Census, 104 - 05; U.S. Census, Sixth Decennial Census, 60 - 63, 234 - 39, 256; U.S. Census, Seventh Decennial Census (Washington, D.C.: Duff Green, 1851), 466 - 74.

19. Wade, Slavery in the Cities; Claudia Dale Goldin, Urban Slavery in the American South 1820 - 1860: A Quantitative History (Chicago, IL: The University of Chicago Press, 1976).

20. "Estate Inventories, 1803 - 1877”; Goldin, Urban Slavey in the American South $1820-1860$. 


\section{Legal and Police Reforms}

As New Orleans entered a phase of demographic and economic growth in the years after the Battle of New Orleans, the New Orleans City Council attempted to order society through the oversight of the city's enslaved population. Based upon traditional constructions of order, a comprehensive system of slave laws emerged, limiting trading with slaves, prohibiting insolence, guarding for runaway slaves on ships, creating a registry of hired-out enslaved labor, and protecting the city from liability for injured slaves. Through key adjustments in existing portions of the law, the City Council sought to increase the ability of the City Guard to promote orderly behavior amongst slaves and those connected to the slave community. Their concerns encompassed social and economic relations not just between enslaved people and their owners, or between slaves and the general public, but also between owners and the city itself.

One of the first ordinances passed in the era contained an article that responded to official suspicions that enslaved people traded illicitly. Concerns over an illicit trade with slaves had long been a concern of government officials since the early eighteenth century. ${ }^{21}$ The new article tied public safety concerns about slaves to controlling the economic position of enslaved people. The article forbade any persons from selling to, purchasing from, and bartering with any slave in "any commodities, goods, or wares or article[,] whatsoever, above the value of five dollars...unless the said slave produce[d] a

21. Article XXIV of Louisiana's Code Noir in French, Historical Collections of Louisiana, 92. 
written permission from his or her master." ${ }^{, 22}$ Although authorities and masters had supported enslaved people's ability to barter and trade as a means of buffering their material well-being, they speculated that enslaved people often stole or fenced illegal goods. The New Orleans City Council felt it needed to intervene through a reiteration of traditional legal norms and established a new mandate to surveil and police slaves in the act of trading.

On October 15, 1817, the New Orleans City Council passed a new municipal slave code and created new legislation that tied public safety concerns to controlling slaves and their actions in public spaces. In the legislation, city officials reaffirmed much of the slave laws passed in the wake of the German Coast Slave Rebellion (1811). Enslaved people were still forbidden from living outside their masters' home without permission and from assembling, except for "divine worship" and Sunday merriment at appointed locations. The ordinance also upheld existing restrictions on free persons, who rented lodgings to enslaved people. ${ }^{23}$ City officials also made some important alterations. Changes included three new articles governing slave morality. Article nine forbade enslaved people from "whooping or halooing...making any clamorous noise, or of singing aloud any indecent song." Article ten threatened the punishment of twenty-five lashes for "every slave who shall be guilty of disrespect towards any white person." Officials also sought new ways to regulate runaways. Article twelve offered a reward for

22. "An Ordinance Containing several provisions of Police, for the City of New Orleans" in New Orleans, Ordinances Ordained and Established by the Mayor \& City Council of the City of New Orleans (New Orleans, LA: J.C. de St. Romes, 1817), 12.

23. New Orleans, Ordinances Issued by the City Council of New-Orleans, 84 - 90. 
"apprehending and securing" any enslaved people aboard ships "with intent to run away." While the fear of slaves escaping by ship was not new, the legislation created incentives for the general public to surveil the actions of enslaved people. ${ }^{24}$

With these articles, public officials recognized that a complex world had emerged on the banks of the Mississippi River. As enslaved people labored on New Orleans' docks, these occupations also presented opportunities for misbehavior. Enslaved people - joined together both figuratively and literally, as groups of dockworkers and bands of chain gangs - acted in ways that could threaten public welfare. The punishments for boisterousness and insolence were an attempt to check the vices of group labor on the city's waterfront. These types of crime did not directly threaten individuals or property in New Orleans. Yet, the actions of enslaved people did offend public morals. This sort of legislation was an attempt to order places where groups of enslaved people threatened the sensibilities of officials, masters, and visitors to the city. Article twelve represented a related issue. Because economic growth brought more vessels than ever to the docks of New Orleans, there was greater potential for enslaved people employed there to make their escapes. ${ }^{25}$ City administrators identified the potential problems and addressed them with laws that increased the things to be vigilant about and supported stiff fines.

24. New Orleans, Ordinances Ordained and Established by the Mayor \& City Council, 216 - 22.

25. Doctor Rarcarn, "Correspondence," Report, Charles F. Heartman Collection 1724 - 1897 (Suite 319, Building 38, Xavier University of Louisiana, 1 Drexel Drive, New Orleans, LA 70125, 1822). 
A month later, New Orleans City Council passed a new ordinance that tied public safety concerns about slaves to surveillance of slaves hired-out in the city. While there already had been a system regulating hired out slaves, the new municipal law mandated that slave hirelings be licensed by the mayor's office, as opposed to simply identifying them as a master's property. The mayor's office issued distinct brass badges with identification numbers to all masters who registered their enslaved people with the office. The mayor ended up with a ledger containing the name, age, and build of all enslaved people legitimately working as day laborers within New Orleans. The new ordinance also contained punishments for counterfeiting badges, hiring enslaved people without badges, refusing to accept work, and "demanding compensation exceeding that above fixed." This, too, was an attempt by New Orleans City Council to gain more control over owners and employers of slaves. At the same time, it also made slave hirelings more visible and policeable. While there had been rules for hiring-out slaves earlier, these new regulations made slave labor more visible within the city, an important policing tool. By regulating where slave hirelings would meet and how they would look, city bureaucrats had greater command of the slave population and, more importantly, any individuals liable to create disorder. ${ }^{26}$

Officials also created a number of laws to order the urban environment and slaves within it. This legislation included a resolution prohibiting enslaved people from gaining

26. Police Code, or Collection of the Ordinances of Police Made by the City Council of New Orleans (New Orleans: Printed by J. Renard, Printer, 1808), 248 - 54; New Orleans, Ordinances Ordained and Established by the Mayor \& City Council, 222 26. 
passage on carts and an ordinance that specified the hours when enslaved people could legally worship in temples, churches, and other religious buildings. ${ }^{27}$ The latter ordinance held that enslaved people could only congregate between sunup and sundown on Sundays. It was an attempt to force slaves into standard forms of religious practice. In particular, the City Council took aim at African religious ceremonies at Congo Square and at slave wakes. ${ }^{28}$ Collectively, these ordinances mandated greater oversight of New Orleans' slave population. As the legislation prohibited certain actions of enslaved people, it also subjected enslaved and free persons of color to new forms of surveillance. These laws attempted to promote public order by giving the City Guard more tools to engage people of color.

In 1836, the New Orleans City Council passed legislation that reformed the city's police system. The law broke up the patrols of groups of watchmen. In its place, the ordinance established a system of individual watchmen walking beats. Scholars have pointed to the 1836 ordinance, as the demilitarization of the New Orleans City Guard. In the legislation, the City Guard no longer policed the streets of New Orleans in military formation. The ordinance also replaced the City Guard's firearms with police clubs. The

27. New Orleans, A General Digest of the Ordinances and Resolutions of the Corporation of New-Orleans, 307; New Orleans, A Digest of the Ordinances, Resolutions, by-Laws, and Regulations of the Corporation of New Orleans, and a Collection of the Laws of the Legislature Relative to the Said City (New Orleans, LA: G. Brusle, 1836), 93.

28. Benjamin Henry Boneval Latrobe, Impressions Respecting New Orleans: Diary \& Sketches, ed. Samuel Wilson Jr. (New York, NY: Columbia University Press, 1951), 49 - 51; Donaldson, "A Window on Slave Culture”; Evans, Congo Square; Wegmann, "No Ordinary, No Earthly Scene." 
demilitarized police group was an attempt to control the police organization and dissuade the patrols from coming in conflict with individuals throughout the city. At the same time, the system made New Orleans City Guard much like that in other cities throughout the United States. The new organization made policing slavery different. In the years that followed, policing slavery would be done in the individual encounters between guardsmen and slaves. $^{29}$

Collectively these laws and ordinances influenced the policing of slavery. In the years after the Battle of New Orleans, the City Council passed legislation to order New Orleans and its slavery. Legislators passed laws focused on many different facets of the actions of enslaved people. While running away and rebellion were still concerns, authorities dictated how enslaved people worked, prayed, and, perhaps more importantly, acted in public spaces.

\section{Policing Slavery in Practice}

On July 5, 1824, Lieutenant C. Dutillet submitted a report to Louis Philippe de Roffignac, New Orleans' mayor, containing the entire reported arrests of the previous night and early that morning. As one of the highest ranking police officials, it was Dutillet's responsibility to submit "the said report...before the mayor, on the opening of

29. "An Ordinance Concerning the Organization of the City-Watch," in A Digest of the Ordinances, Resolutions, by-Laws, and Regulations of the Corporation of New Orleans, and a Collection of the Laws of the Legislature Relative to the Said City, in A Digest of the Ordinances, Resolutions, by-Laws, and Regulations of the Corporation of New Orleans, and a Collection of the Laws of the Legislature Relative to the Said City (New Orleans, LA: G. Brusle, 1836), 105 - 15; Rousey, Policing the Southern City, 11 39. 
his office. ${ }^{30}$ In the handwritten ledger of the Rapport du Lieutenant de la Garde (Report of the Lieutenant of the Guard) stated:

At 6:30[,] the guard of the central post conducted two negresses named Prudence belonging to Mr. Nichols and Eve to Tototte had a package of merchandise and 7 and $1 / 2$ escalins [coins] deposited in the central post.

At 7:00[,] Mr. John Brikitt required two men to bring to the police jail the negro, who claims to be free, named Isaac Sipson and accused of having stabbed someone. Mr. Brikitt is to appear at the Mayor's Office.

At 8:00[,] Mr. Richard Salter brought to the central post and later to the police jail his negro named Charles to be at the disposal of the police.

At 12:30[,] the south patrol brought to the central post and later the police precinct a person named Passe-Partout found sleeping on the levée facing the St. Louis street.

At 11[,] the patrol of Faubourg Marigny brought to the police jail a negro named John Moon belonging to Mr. Smille to be at the disposal of the police.

At 11:30[,] the north patrol brought to the police precinct someone named Welsh found sleeping in the Herb Market and Latourette found sleeping in the place d'armes

At 1 in the morning[,] Mr. de Mripoix making a round brought to the central post someone named O'connel found sleeping at the corner of Canal and Magazin streets.

At 6:30 in the morning[,] Mr. Laivuture[,] a man of the guard[,] brought to the police jail his negress Sophie to be at their disposal.

During the night[,] the patrol of Faubourg Marigny brought a negress named Violette[,] belonging to Mr. Campeche [,] to the police jail. ${ }^{31}$

Read holistically, the daily account of arrests gives readers a great sense of the shifting constructions of policing and order by the 1820s and 1830s. Of the nine total encounters occurring during the nighttime hours of July 4 and morning of July 5, the City Guard arrested ten total people. These ten individuals give a sense of a new order in policing.

Two important trends are important to be pulled out. First, free people became more prominent in the records. Based upon their names and the lack of a racial modifier, Welsh and O'Connel were not only free but white. Second, the categories of these arrests

30. New Orleans, Ordinances Issued by the City Council of New-Orleans, 54.

31. C. Dutillet, "Rapport Du Lieutenant de la Garde Serve Du 4 Au 5 Juillet 1824," Charles F. Heartman Collection 1724 - 1897 (Suite 319, Building 38, Xavier University of Louisiana, 1 Drexel Drive, New Orleans, LA 70125, 1824). 
follow larger patterns. While there were four unclear crimes, three arrests were for public order crimes, one for property crime, and one for violent crime. The arresting of individuals for public order crimes remained a means for officials to promote public order. In this case, the City Guard also arrested the three free people for crimes against public order. While enslaved people became a smaller percentage of the arrests over time, the ways in which the City Guard policed slaves became the model for policing the community. By arresting individuals for crimes against public morals, specifically sleeping in public, the City Guard attempted to promote a form of public order of New Orleans that included policing minor infractions.

As another part of the police bureaucracy, the actions of the New Orleans City Guard reaffirmed some of the transitions taking place within the City Council. The arrests records - contained in the Reports of the Captain of the Guards - indicate that while enslaved people were arrested at levels more representative of their population, they still were a focus of policing efforts. The 1824 and 1834 Reports of the Captain of the Guards provide an important window into police interactions with enslaved people. While policing slavery remained important, the documents suggest a subtle transition taking within New Orleans.

At its most basic level, the Reports of the Captain of the Guards in 1824 highlight a transformation in the policing slavery. The City Guard arrested enslaved people at a rate most respective of their population in the years examined. In 1814 enslaved people made up $77.5 \%$ of arrests, while making up between 27 and $35 \%$ of the Orleans Parish 
population. ${ }^{32}$ However, ten years later enslaved people made up $35 \%$ of arrests, while making up between $27 \%$ and $30 \%$ of Orleans Parish population. ${ }^{33}$ The trend would continue in the Reports of the Captain of the Guards in 1834, as enslaved people made up $41 \%$ of arrests, while making up between $23 \%$ and $31 \%$ of the total population of New Orleans. ${ }^{34}$ The decrease in the arrest rate of enslaved people to a more proportional level suggested that after the turbulent time of rebellion and warfare, different norms for policing emerged, even as legislation reflected concerns over slaves' actions and whereabouts.

Within these records, the New Orleans City Guard continued to most commonly arrest enslaved persons for crimes against public order, including running away. In 1824 and 1834 , public order crimes accounted for $80 \%$ and $77 \%$ of the total arrests of enslaved people (See Tables 9 and 10).

32. Of the 1986 total arrests reported from January through December in 1824, I created a random sample of 318 entries. Of the 318 entries, 307 crimes had been committed by person with identifiable status. From these records, free people made up 196 (63.84\%) of arrests. "Report of the Captain of the Guards"; U.S. Census, Third Decennial Census; U.S. Census, Fourth Decennial Census.

33. "Report of the Captain of the Guards"; U.S. Census, Fourth Decennial Census; U.S. Census, Fifth Decennial Census.

34. Of the 6134 arrests records in 1834, I created a random sample of 360 records (a $5.01 \%$ margin of error). Of the 360 records, 346 had identifiable status. From these records, free people made up 204 (59\%) of the arrests. "Report of the Captain of the Guards," Jan - Mar, Louisiana Division/City Archives (New Orleans Public Library, 219 Loyola Ave., New Orleans, LA 70112, 1834); "Report of the Captain of the Guards," April - May, Louisiana Division/City Archives (New Orleans Public Library, 219 Loyola Ave., New Orleans, LA 70112, 1834); "Report of the Captain of the Guards," Jun - Dec, Louisiana Division/City Archives (New Orleans Public Library, 219 Loyola Ave., New Orleans, LA 70112, 1834). 
Table 9: The sample of the Reports of the Captain of the Guards in 1824

\begin{tabular}{|l|r|r|r|r|}
\hline Crimes & $\begin{array}{l}\text { Slaves } \\
\text { Arrested }\end{array}$ & $35 \%$ & $\begin{array}{l}\text { Free } \\
\text { People }\end{array}$ & $65 \%$ \\
\hline Violent & 3 & $4 \%$ & 23 & $16 \%$ \\
\hline Property & 11 & $14 \%$ & 12 & $8 \%$ \\
\hline Public Order & 64 & $82 \%$ & 108 & $73 \%$ \\
\hline Unknown & 0 & $0 \%$ & 4 & $3 \%$ \\
\hline Total & 78 & & 147 & \\
\hline
\end{tabular}

Source: "Report of the Captain of the Guards," Charles F. Heartman Collection 1724 1897 (Suite 319, Building 38, Xavier University of Louisiana, 1 Drexel Drive, New Orleans, LA 70125, 1824).

Table 10: The sample of the Reports of the Captain of the Guards in 1834

\begin{tabular}{|l|r|r|r|r|}
\hline Crimes & $\begin{array}{l}\text { Slaves } \\
\text { Arrested }\end{array}$ & $30 \%$ & $\begin{array}{l}\text { Free } \\
\text { People }\end{array}$ & $70 \%$ \\
\hline Violent & 1 & $2 \%$ & 13 & $9 \%$ \\
\hline Property & 11 & $18 \%$ & 16 & $11 \%$ \\
\hline Public Order & 48 & $77 \%$ & 111 & $78 \%$ \\
\hline Unknown & 2 & $3 \%$ & 2 & $1 \%$ \\
\hline Total & 62 & & 142 & \\
\hline
\end{tabular}

Source: "Report of the Captain of the Guards," Jan - Mar, Louisiana Division/City Archives (New Orleans Public Library, 219 Loyola Ave., New Orleans, LA 70112, 1834); "Report of the Captain of the Guards," April - May, Louisiana Division/City Archives (New Orleans Public Library, 219 Loyola Ave., New Orleans, LA 70112, 1834); "Report of the Captain of the Guards," Jun - Dec, Louisiana Division/City Archives (New Orleans Public Library, 219 Loyola Ave., New Orleans, LA 70112, 1834).

These arrests came in various forms and illustrate the different types of connections between enslaved persons and public officials. As enslaved people ran away, drank, loitered on the levee, and fired guns, they tested the limits of what the city found acceptable (See Table 9.A. and 10.A. in the Appendix for a complete list of crimes in 1824 and 1834). While runaway slaves had posed a great problem to New Orleans 
throughout the early nineteenth century, the New Orleans City Guard began to arrest enslaved people less commonly for this crime. Of the total arrests of enslaved persons, $32 \%$ and $27 \%$ of these records were for marronage or running away in 1824 and 1834 , respectively. The changing arrest pattern for runaway slaves indicated both a decline in the policing of runaways in a time of relative stability and the policing of other public moral crimes, like insolence. The City Guard also arrested enslaved persons for a number of other disorderly behaviors. Collectively, these crimes against public order demonstrate that the city was a complex place with many different ways for enslaved persons to rub against public authorities.

Arrests of slaves for violent and property crimes made up smaller proportions of the arrest records. Within the crime statistics of the New Orleans City Guard, property crimes made up the second largest group of arrests, making up 14\% and $18 \%$ of arrests of enslaved people in 1824 and 1834 . While property crimes made up $28 \%$ of the arrests in 1814, these types of arrests made up a smaller percentage of total arrests in the years after the War of 1812. The New Orleans City Guard arrested enslaved persons for violent crimes at a lower rate than the previous two categories. Of the total arrests of slaves, $4 \%$ of the arrests of enslaved people were for violent crimes in 1824 and $2 \%$ in 1834.

These records also indicated that slaveowners continued to accept local authority as an important resource. A comparison of the Reports of the Captains of the Guard in 1814,1824 , and 1834 suggested that masters increasingly had their own slaves arrested over time. While $5 \%$ of the arrests of enslaved people were at the behest of their owners in 1814 , by 1824 the percentage rose to $12 \%$. In 1834, these types of arrests accounted for $17 \%$ of all arrests of enslaved persons (See Table 11). 
Table 11: Slaves arrested at the behest of their masters in the Reports of the Captain of the Guards in 1814,1824 , and 1834

\begin{tabular}{|c|c|c|c|c|c|c|}
\hline & 1814 & $\begin{array}{c}\% \text { of } \\
\text { slaves } \\
\text { arrested }\end{array}$ & 1824 & $\begin{array}{c}\% \text { of } \\
\text { slaves } \\
\text { arrested }\end{array}$ & 1834 & $\begin{array}{c}\% \text { of } \\
\text { slaves } \\
\text { arrested }\end{array}$ \\
\hline $\begin{array}{c}\text { Slaves } \\
\text { Arrested } \\
\text { at the } \\
\text { behest } \\
\text { of their } \\
\text { Masters }\end{array}$ & 7 & $5.22 \%$ & 13 & $11.71 \%$ & 24 & $16.90 \%$ \\
\hline $\begin{array}{c}\text { Total } \\
\text { Arrests } \\
\text { of } \\
\text { Slaves }\end{array}$ & 134 & 111 & & 142 & \\
\hline
\end{tabular}

Sources: "Report of the Captain of the Guards." Charles F. Heartman Collection 1724 1897. Suite 319, Building 38, Xavier University of Louisiana, 1 Drexel Drive, New Orleans, LA 70125, "Report of the Captain of the Guards," Charles F. Heartman Collection 1724 - 1897 (Suite 319, Building 38, Xavier University of Louisiana, 1 Drexel Drive, New Orleans, LA 70125, 1824), "Report of the Captain of the Guards," Jan - Mar, Louisiana Division/City Archives (New Orleans Public Library, 219 Loyola Ave., New Orleans, LA 70112, 1834); "Report of the Captain of the Guards," April - May, Louisiana Division/City Archives (New Orleans Public Library, 219 Loyola Ave., New Orleans, LA 70112, 1834); "Report of the Captain of the Guards," Jun - Dec, Louisiana Division/City Archives (New Orleans Public Library, 219 Loyola Ave., New Orleans, LA 70112, 1834).

Enslaved people were not commonly arrested at the behest of their masters, but some masters had their slaves arrested and, in doing so, promoted government's place in policing slavery. Even if masters did so simply so not to be bothered with discipline, having the City Guard arrest ones slaves made the municipality an accepted part of slavery within New Orleans. 
The New Orleans City Guard became a preventative force by the 1830s. As the City Council created new legislation to police crimes that threatened public safety and public morals, it gave the City Guard expansive tools to surveil and arrest enslaved people. This new mandate increased the City Guard's authority in the ordering of New Orleans.

\section{Conclusion}

In the years after 1815, the theory and practice of policing slavery evolved in New Orleans. While the period of warfare and rebellion had set the stage for new approaches, municipal authorities took on a new form by the 1820s. The New Orleans City Council continued to assert the right to assume some of the responsibilities of mastery as part of the greater good, while the City Guard continued to arrest enslaved persons for property and public order crimes. By the 1830s, however, New Orleans had new ways to arrest, surveil, and police its population of enslaved people, including the policing of public morals. Moreover, while masters were responsible for the actions of their slaves, masters themselves became the object of policing reforms. This type of oversight became an important component of urban slavery in Atlantic slaveholding cities in the nineteenth century. 


\section{CHAPTER 6}

Salvador

$1838-1850$

\section{Introduction}

On May 7, 1840, Theodozio Provedes Froes, the Prezidente of Bahia passed a disposition stating that in "all of the cases of infractions perpetrated by children or slaves, their fathers or masters are held responsible." For good measure, he added that "in cases

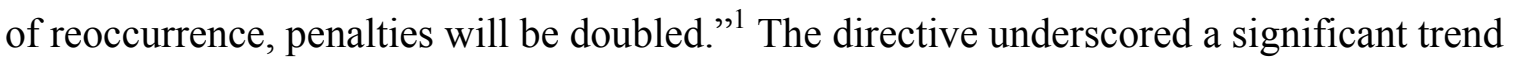
taking place in early nineteenth-century Salvador. While local authorities - provincial and municipal officials — created responsive ordinances and policing procedures during the turbulence of the 1830 s, a new order emerged in the years that followed. In passing legislation, like the disposition, officials attempted to combat slave disorders through regulations aimed at surveilling and controlling masters. Police forces responded by arresting slaves at a rate consistent with their representation in the city's population. What emerged from these efforts was a strong bureaucratic and preventative form of policing slavery.

The chapter traces Salvador from the aftermath of the Revolta dos Malês to midcentury. While the commercial development of the city initially stagnated, Salvador's population grew. At the same time, the population of enslaved people fell within the city because of Brazil's internal slave trade. Provincial and municipal officials retained the power to institute numerous police reforms, including increasingly restrictive laws and

1. Arquivo Minicipal de Salvador, Repertório de Fontes Sobre a Escravidão, 66. 
ordinances on enslaved people and their masters. These laws and ordinances made slaveowners register slave trades, established taxes on slaves traded, and mandated property owners destroy places slaves ran away to in the city. However, Salvador's police forces arrested slaves at a rate more akin to their percentage of the population than in previous years. Shifts in legislating and policing of slavery in Salvador established a strong bureaucratic police presence aimed at the prevention of crime.

The chapter argues that local provincial and municipal government officials expanded upon previous theories and practices of policing of slavery to create a new bureaucratic system based on surveillance in Salvador between 1838 and 1850. The chapter adds another dimension to what we already know about slavery in Salvador in the era. While many historians have focused on the Revolta dos Malês and its impact on enslaved people, free persons of color, and the slave trade, they have emphasized the impact of the slave rebellion at the expense of the transformations within the city itself. ${ }^{2}$ Enslaved people remained an important target of policing slavery. However, the development of the city and the actions of masters also influenced official conceptions of public order. Responsive legislation made slaveowners the object of the law. Legislators suggested that masters be more responsible for the actions of their enslaved people. While the arrest records do not bear out a police focus on slaveowners, they do indicate that slaves remained an important aspect of policing order.

2. Graden, From Slavery to Freedom in Brazil; Reis, Slave Rebellion in Brazil. 


\section{The City}

The 1830s and 1840s were a turbulent but positive time for Bahian sugar and tobacco economies. While the turmoil of Brazilian independence and changing consumption patterns had undercut profits by the 1820s, Bahian sugar and tobacco economies recovered by the 1840 s. Increased sugar production throughout the world eroded profits of Bahian sugar by the 1820s. The sugar industry only recovered when Brazilian political officials brokered international trade agreements around 1845 . In these trade agreements, Great Britain and Germany lowered their tariffs on low-grade or unrefined sugar and kept high tariffs on refined sugar. The tariff changes limited trade in refined sugar. This trend continued to define the Bahian sugar industry and limited its room for expansion in the years that followed. Nonetheless, Bahian planters capitalized on and expanded sugar production to unprecedented proportions by $1850 .^{3}$ Similar events affected tobacco exports. While a transition to cigar tobacco in Europe and the Brazil's 1831 abolition of the slave trade had effectively cut off two main export markets for Bahian tobacco, the industry recovered by the $1840 \mathrm{~s}$. An upward trend in international tobacco prices made tobacco production more profitable in that era. Bahian tobacco growers and producers responded with a transition to leaf tobacco. The transition allowed Bahian tobacco to be used in cigars. Bahian merchants also created

3. F.W.O Morton, "Growth Innovation: The Bahian Sugar Industry, 1790 - 1860," Canadian Journal of Latin American and Caribbean Studies 5, no. 10 (1980): 37 -54; Barickman, Bahian Counterpoint, 38 - 39. 
tobacco refineries. As a result, Bahian tobacco industry recovered by the 1840 s. These economic trends enabled commercial and demographic expansion in Salvador. ${ }^{4}$

These larger trends had a profound impact on Salvador's population. The city remained a metropolis of regional commerce. Scholars have suggested that the population of the city increased from 69,836 to 81,544 between 1838 and $1850 .{ }^{5}$ Population growth affected both the Cidade Baixa and the Cidade Alta. The physical limits of the city continued to expand, however, the traditional perceptions of the two different parts of the city remained. Visitors continued to be struck by the differences of the lower and the upper city. ${ }^{6}$ Yet, the demographic and physical growth meant that police officials had a larger cityscape and more individuals to police than they had in previous years. Ordering the environment required laws that empowered local authorities through a system of bureaucratic surveillance.

Commercial and demographic growth highlights a transformation in policing and order in Salvador. The development of the city created a difficult task for government officials. These authorities had to preserve order within a changing city. Enslaved people steadily made up a smaller percentage of the population and a lower proportion of the city's labor force. Even so, enslaved people and their owners remained a focus of local administrators, suggesting that managing the institution of slavery remained both a

4. Barickman, Bahian Counterpoint, 32 - 33.

5. Mattoso, Bahia, 138.

6. Alexander Marjoribanks, Travels in South and North America (London, UK: Simpkin, Marshall, and Company, 1853), 41 - 48; Robert Abé-Lallement, Reise Durch Nord=Brasilien Im Jahier 1859 (Leipzig: F.D. Bradhaus, 1860), 10. 
high priority for police power and a justification for its existence. Officials responded with bureaucratic efforts that refined the surveillance and policing of slavery in Salvador. ${ }^{7}$

\section{Slaves}

While the percentage of enslaved people declined, they remained an important part of Salvador and their actions had significant repercussions in the era. Both the actions of enslaved people and their labor affected official conceptions of order. Even a reduced slave presence in the city, justified official assertions of continued and enhanced surveillance and policing. However, as masters and traders sold their enslaved people to individuals in other provinces of Brazil, authorities also created laws for supervising slaves and their masters.

While the slave population decreased, enslaved people remained an important part of conceptions of order within Salvador. While the city had a $42 \%$ slave population in 1835 , it fell to $27 \%$ in 1855 . The decline in the population percentages suggests that masters sold and emancipated their slaves along with any possible natural changes in the general population of Salvador. It also indicates that slaves may not have been the only source of labor within Salvador. Yet, slaves continued to be a significant part of Salvador's population. They also remained a focus of authorities in Bahia. ${ }^{8}$

7. Flory, Judge and Jury in Imperial Brazil, 131 - 34; Barman, Brazil, 196 - 201; Brown, “"A Black Mark on Our Legislation'," 98.

8. Within the context of an estimated population increase of 3,592 of 1835 and 1840 , a simple growth of the free population and stagnation of slave population does not make up the population decrease of $3.65 \%$. The estimated is comprised of the estimated slave populations in 1835,1855 , and 1872 . In which the average yearly decrease in slave 
Enslaved people endured in official conceptions of public order. The Revolta dos Malês had proven that the actions of slaves and their masters had severe ramifications on Salvador. Although the slave population decreased after the revolt, legislators still responded with new ways to oversee slavery and police the actions of enslaved people. Authorities prioritized a focus on tracking the slave community through their masters, a practices that had been central to reactions to the rebellion. Yet, legislators established new forms of the surveillance. They created laws and ordinances that required masters to register transactions of slaves as commodities, established taxes on traded slaves, made masters financially culpable for crimes committed by their slaves, and required property owners to destroy lands to where slaves ran away.

\section{Laws and Police Organization}

Alexander Marjoribanks arrived in Salvador around 1850. The Scottish traveler and author of travel narratives collected notes on the trip. Marjoribanks paid particular attention to the city and its institutions. His notes contained detailed accounts and comments on clearly observable local practices. Of the police, he noted that:

They have a military police, who go generally in parties of three or four, armed with swords and muskets. I think it would be an improvement were they to adopt the Chinese fashion, and carry a whip also, as the police of Pekin, the capital of China, in addition to their swords are furnished with a whip, with which they chastise in a summary manner, and upon the spot, those who make a noise or any disturbance on the streets, not of sufficient consequence to warrant their being

population between 1835 and 1855 is estimated at .73\%. Nascimento, Dez Freguesias Da Cidade Do Salvador, 97; Andrade, A Mão de Obra Escrava Em Salvador 1811 1860, 29 - 30; Chaloub, Visões Da Liberdade, 41 - 80; Reis, Slave Rebellion in Brazil, 6; Richard Graham, "Nos Tumbeiros Mais Uma Vez"; Nishida, Slavery and Identity, 1 26; Richard Graham, "Another Middle Passage?" 
taken into custody. Nobody is allowed to carry bowie knives, or sticks above a certain size. ${ }^{9}$

The account provided an important insight into early nineteenth-century Salvador. Marjoribanks points to the relationship of police, law, and order. As the author noted prohibitions on offensive weapons and certain types of actions, he also suggested some of the fundamental weaknesses of police forces in the city. Marjoribanks felt that Salvador's police were ineffective because on the one hand, they could not use their swords or muskets to dispense immediate punishment on people who had committed minor crimes but, on the other hand, the police did not arrest people caught in the act of minor “disturbance." However, Majoribanks's observation indicated the close relationship of police, law, and order as it stood by mid-nineteenth century. Legislators and the police forces remained agents of order within Salvador. Provincial and municipal government officials regulated slaves and their masters to promote public welfare and the police that applied it.

Within the context of the time period, the Bahian prezidente (governor) and the Bahian Legislative Assembly became the most important figures in passing legislation both for the Province and the city of Salvador itself. Provincial institutions would eclipse the municipal câmara in passing municipal laws in this era. Just as the provincial assembly had passed laws in the wake of the Revolta dos Malês-including Lei $n^{\circ} 1$ (the Declaration of Martial Law in wake of the rebellion) and Lei $n^{\circ} 14$ (setting up the captazia system) - it established laws that directly and indirectly impacted slavery within Salvador.

9. Marjoribanks, Travels in South and North America, 46 - 47. 
On June 15,1838 , the legislature passed a law that gave authorities an account of traded slaves. This law was an attempt to rein in Bahia’s slaveowners. Lei ${ }^{\circ} 74$ held that all exchanges of enslaved people as property needed to go through the Escrivão de Paz (scribe of the peace). While $L e i^{\circ} 74$, too, was a provincial-wide reform, it reinforced a key practice to maintaining an orderly slave society. Just like $L e i^{\circ} 14$, Lei ${ }^{\circ} 74$ attempted to make the actions of enslaved people and their master more visible before government officials. While $L e i^{\circ} 14$ created a registry of slaves at work in captazias in the city, Lei ${ }^{\circ} 74$ established a registry of slaves traded by masters. Therefore, Lei ${ }^{\circ} 74$ had a wide appeal, as it traced where enslaved people lived and worked. Lei ${ }^{\circ} 74$ was part of the effort of provincial government to have greater accountability of the slave population in Salvador. $^{10}$

Provincial officials took up a similar measure to track changes in Bahia's slave population as a result of the internal slave trade. One month after the passage of $L e i^{\circ} 74$, the Bahian Legislative Assembly passed Lei ${ }^{\circ} 86$. The law established a tax on slaves being traded to other parts of Brazil. Lei ${ }^{\circ} 86$ would be one in a series of thirteen laws passed between 1838 and 1848 that focused on the taxation of traded slaves. Bahian officials attempted to control and make a profit off of Brazil's internal slave trade through these laws. It also made slaveowners more accountable for their slaves, as authorities created the registries of those slaves traded. Like $L e i^{\circ} 74$, Lei ${ }^{\circ} 86$ was a law that

10. Bahia, "N. 74. Lei de 15 de Junho de 1838," in Collecção Da Leis e Resoluções Da Assemblea Legislativa Da Bahia, Sanccionadas e Publicadas Nos Annos de 1835 a 1838., Vol 1. (Salvador, BA: Typ. Constitutional de França Guerra, 1863), 246 -47 . 
attempted to account for slaves. Through these laws, authorities had an ability to track the larger movements of enslaved people inside and outside the city. ${ }^{11}$

Prezidente Theodozio Froes' general disposition of May 8, 1840 was an important legal tract. The disposition regulated masters by making them fiscally responsible for the actions of their slaves. The mandate also implied a degree of official oversight by the police for slaves and their masters. When slaves committed crimes, officials held masters responsible for damages. In other words, government officials had the right to punish slaves and fine masters. While these laws had little to do with policing slaves on the streets of Salvador at face value, they added to the system of surveillance that engaged masters. By making masters fiscally responsible for the actions of their slaves, the disposition both mandated masters' oversight of their slaves and justified police oversight of both slaves and masters. ${ }^{12}$

The reversal of the Liberal political agenda marked national politics in the $1830 \mathrm{~s}$ and 1840s. While the Liberal political party championed local autonomy and won national political battles in the 1830 s, Conservatives initiated a period of centralizationcalled the Regresso - as they took control of the monarchy and Brazil's General Assembly in the late 1830s. Several of these Conservative reforms affected policing. In

11. Fundação Cultural do Estado da Bahia, Legislação Provincial Da Bahia Sobre o Negro, 1835 - 1888 (Salvador, BA: Fundação Cultural do Estado da Bahia, 1996), 25 26; Richard Graham, "Nos Tumbeiros Mais Uma Vez"; Richard Graham, "Another Middle Passage?"

12. Arquivo Minicipal de Salvador, Repertório de Fontes Sobre a Escravidão Existentes No Arquivo Municipal de Salvador as Posturas (Salvador, Bahia, Brazil: Fundação Gregório de Mattos, Prefeitura Municipal do Salvador, 1988), 66. 
December 1841, Conservatives within Brazil's General Assembly passed a revised criminal code. One of the central functions of the revised code was to rein in the juiz da paz. While the juiz da paz was a locally elected official, the powers of policing would now be invested in nationally appointed-governors and police chiefs. The reform allowed for centralized state control of police actions throughout Brazil. While the new criminal code may not have directly transformed the policing of slavery, it did create a change in the composition of police authority. After the revised code, provincial officials commanded all policing operations within Salvador. ${ }^{13}$

Salvador's câmara also passed legislation affecting the policing of urban slavery. The câmara responded to the actions of enslaved people, who ran away and lived with other runaways in the city. Salvador's câmara passed an ordinance that required all owners of land to destroy any quilombos on their property in 1844 . If they failed to do so, these landowners would be punished with a fine of $20 \$ 000$ mil-réis. ${ }^{14}$ These laws underscored a local emphasis on ordering the city, along with its inhabitants. Like legislation in New Orleans, the law was part of a preventative emphasis on actions within the slave community. By eliminating places for slaves to run away to within the city, authorities attempted to combat slave crimes before they threatened the security of Salvador. ${ }^{15}$

13. Brown, “'On the Vanguard of Civilization'," 14 - 15.

14. In this year, $20 \$ 000$ was $1 / 25$ of the price of a healthy skilled African slave (493\$750). Richard Graham, Feeding the City, 213 - 218.

15. Fundação Cultural do Estado da Bahia, Legislação Provincial Da Bahia Sobre o Negro, 76. 
In the same year, the Bahian Legislative Assembly passed Lei ${ }^{\circ} 291$. The law created taxes on free people of African descent working with slaves as sedan carriers within Salvador. The main purposes of the tax were to create a registry of workers and raise revenue. While the law focused primarily on the free people of African descent, these types of laws paved the way for legislation that restricted the ways in which slaves labored within the city by the second half of the nineteenth century. This type of legislation allowed authorities to expand its control over Salvador's labor force. As the fees from the tax were used to surveil and police laborers, the legislation directly influenced the entire population of people of color. A similar law was applied to enslaved people. In 1857, a tax on ganhadores (day-laboring slaves) led to an effective strike of slaves and outrage from their masters. Even though the 1857 tax represented an overreach by authorities, it was part of a pattern of oversight dating back to Lei ${ }^{\circ} 291 .^{16}$

Brazil's abolition of the Atlantic slave trade in 1850 (Brazil's final and official abolition) also affected the trajectory of slavery in Salvador. It effectively marked a new era for slavery in two ways. First, abolition of the Atlantic slave trade was another assertion of centralization. Through these actions, Conservatives in Brazil's General Assembly created a central policy on slaves and suppressed tensions that had risen between Brazil and Great Britain. As Great Britain championed the abolition of slavery and the international slave trade, it pressured Brazil to follow suit by interrupting Brazil's

16. Fundação Cultural do Estado da Bahia, Legislação Provincial Da Bahia Sobre o Negro, 35; João José Reis, “"The Revolution of the Ganhadores': Urban Labour, Ethnicity and the African Strike of 1857 in Bahia, Brazil," Journal of Latin American Studies 29, no. 2 (May 1997): 355 - 93. 
illicit African slave trade that had been ineffectually prohibited in 1831 . Second, while the slave trade had continued after Brazil's 1831 abolition, enforcement of the 1850 abolition effectively closed off importations of slaves. As the abolition shut down the Atlantic slave trade, it created new strains on Brazil's labor supply. Just like the 1831 abolition, the 1850 abolition fostered higher prices for slaves in the emerging regions in Brazil. These prices accelerated an internal slave trade within Brazil. ${ }^{17}$

While legislators appeared to focus on slaveowners and taxes, they also changed how slavery was policed. Provincial authorities realized that ordering slavery required policing slaves and the surrounding community in the aftermath of the Revolta dos Malês. While establishing regulations to prevent slaves from running away was central to policing slavery, so too were laws making their masters more accountable. At the same time, registries of slave trades and traded slaves enabled authorities to have insight on the population whom they policed. Collectively, legislators made slavery more policeable in Bahia and Salvador.

\section{Policing Slavery in Practice}

On September 20, 1847, the Registro de Portarias (a hand-written ledger of the actions of the Policia) reported the five official actions of senior provincial officials and administrators of jails on that day. While the Registro de Portarias recorded events of the Policia throughout Bahia, the account of September 20, 1847 reported specifically on Salvador:

17. Barman, Brazil, 230 - 35; Richard Graham, "Nos Tumbeiros Mais Uma Vez"; Richard Graham, "Another Middle Passage"; Graden, From Slavery to Freedom in Brazil, 33 - 42. 
The Administrator of the prison jail and house of correction punished with 20 lashes of a cane the African prisoner Maria Ritta for insulting the sentinel. The Administrator of the prison of Aljube delivered the slave Roque belonging to Doma Flornida Maria de Carmo after being punished with thirty lashes.

The Senior Official of the State set free Maria Euzbria who was collected by the same order.

The Senior Official of the State released the African Paulo from Aljube.

The Administrator of Aljube had deposited the African Paulo who will be moved to the Police Quarters.

Read holistically, the Registro de Portarias on September 20, 1847 indicated something specific about policing and order. Unlike the Parte Geral, and more like the reports of the Juiz da Paz, the Registro de Portarias focused on more than arrests. These documents contained a range of information, from the movement of troops and quarantined items to the arrest, judgement, punishment, transfer, and release of individuals. Yet, because the Policia was only one of the police groups that policed slavery in Salvador, its Registro does not speak to the entirety of police actions in the city. The Policia remained the enforcement arm of both camâra and provincial legislators and their reforms aimed at the city in the years after the Revolta dos Malês. While the police saw no need to make explicit their reasons for arrests, the records of September 20 suggest something important about the Policia and order. When the Policia arrested and punished individuals for crimes against public order, the Policia sought to regulate public morals and prevent minor crimes from disrupting society or threatening public welfare. ${ }^{19}$

18. "Portaria,” Registro de Portarias (1847 - 1849), Maço 5622, Policia (Salvador, BR: Arquivo Público do Estado da Bahia, 1847).

19. Brown, "'On the Vanguard of Civilization'," 64; Kraay, Race, State, and Armed Forces in Independence-Era Brazil, 218 - 50. 
Of the 864 total recorded actions within the Registro de Portarias (administrative records) between January 1, 1847 and December 30, 1847, the chapter relies on a random sampling of 267 of these records. In these 267, the Policia detailed troop movements, quarantined items, and specific actions related to policing individuals. The 179 stated police actions taken in response to certain individuals provide great insight to the construction of order and the way policing institutions interacted with slaves (See Table 12).

Table 12: Breakdown of actions taken in relation to individuals within the Registro de Portaria from January to December 1847

\begin{tabular}{|l|r|c|}
\hline & $\begin{array}{c}\text { Actions } \\
\text { taken } \\
\text { related } \\
\text { to } \\
\text { Slaves }\end{array}$ & \\
\hline Arrest & 40 & $73 \%$ \\
\hline Judgment & 1 & $2 \%$ \\
\hline Release & 9 & $16 \%$ \\
\hline Punishment & 5 & $9 \%$ \\
\hline Total Records & 52 & \\
\hline Total Actions & 55 & \\
\hline
\end{tabular}

Source: Registro de Portarias (1847 - 1849), Maço 5622, Policia (Salvador, BR: Arquivo Público do Estado da Bahia, 1847).

Within these records, several patterns become clear. First, the Policia arrested slaves at a rate closer to their percentage of the population, than in previous periods. Of the 179 recorded actions, 110 records were of arrests. Slaves made up thirty-six percent of all these arrests. As slaves composed between $42 \%$ and $28 \%$ of the city's population in between 1835 and 1855, these arrest records appear much closer to their representative 
population than previous years - as slaves made up 24\% and 14\% of arrests in 1831 and 1837, respectively. This suggests that as legislation on the slave population proliferated, police forces followed suit. The true significance of these arrests rates is only visible longitudinally, in other words. While the population of enslaved people in Salvador declined in both absolute and proportionate terms, the police arrested enslaved people more often than they had done earlier in the century. ${ }^{20}$

Of the forty arrests of enslaved people, only fourteen associated them with specific crimes. These numbers are small but highly suggestive, as the overwhelming majority of these arrests were for crimes against public order (See Table 13). Of the fourteen total reported arrests of slaves, thirteen were for public order crimes. The Policia arrested enslaved people for running away and violating the Edict of February 20. Table 13: Crime statistics within a sample of the Registro de Portaria from January to December 1847

\begin{tabular}{|l|r|r|r|r|}
\hline Crime Type & $\begin{array}{c}\text { Slaves } \\
\text { Arrested }\end{array}$ & $29 \%$ & $\begin{array}{c}\text { Free } \\
\text { People }\end{array}$ & $71 \%$ \\
\hline Violent & 0 & $0 \%$ & 5 & $15 \%$ \\
\hline Property & 1 & $7 \%$ & 1 & $3 \%$ \\
\hline Public Order & 13 & $93 \%$ & 25 & $74 \%$ \\
\hline Unknown & 0 & $0 \%$ & 3 & $9 \%$ \\
\hline Total & 14 & & 34 & \\
\hline
\end{tabular}

Source: Registro de Portarias (1847 - 1849), Maço 5622, Policia (Salvador, BR: Arquivo Público do Estado da Bahia, 1847).

20. Most likely, police officials both started to arrest slaves and to list their status more often. Registro de Portarias (1847 - 1849), Maço 5622, Policia (Salvador, BR: Arquivo Público do Estado da Bahia, 1847); "Parte Geral Da Guarda Policial"; Suixaz, João Lourenço Suixaz to Prezidente do Provincia; Suixaz, João Lourenço Suixaz to Prezidente do Provincia. 
Running away was the most commonly listed reason for arrests of enslaved people. They accounted for twelve or $86 \%$ of all arrests of enslaved people. The records maintained that the police arrested slaves for violating the Edict of February 20 and for stealing once each (See Table 13.A. in the Appendix for a complete list of crimes). ${ }^{21}$

These records indicate that the enslaved people remained an important part of conceptions of public order. While legislators had responded with laws and ordinances that aimed at the slave community through their masters, the Policia focused directly enslaved people. The percentage of arrests of enslaved people actually rose and began to more closely reflect their representative proportion of the city. Enslaved people still came before the police and remained important to their conceptions of public order.

\section{Conclusion}

The theories and practices that guided the policing of slavery transformed in Salvador between 1838 and 1850. The growth of the city created new fiscal and bureaucratic strains upon authorities who were responsible for policing an increasingly larger city. While the population of enslaved people decreased in real and proportional numbers, it remained important within municipal and provincial conceptions of public order. The Bahian Legislative Assembly and Salvador's câmara created a number of laws, ordinances, and mandates that prioritized surveilling and policing of enslaved people and their masters. These movements effectively allowed the Bahian provincial government to assume some of the responsibilities of slave ownership and oversight of

21. Registro de Portarias (1847 - 1849). 
slaveowners. The provincial Policia continued to police and enforce public order crime. The prerogative of bureaucratic police oversight created a stronger police presence that would define Salvador for years to come. 


\section{EPILOGUE}

Within the twenty-first century, policing practices and their relationship to people of African descent have risen to the forefront of national and global discussions. The deaths of African American men and women during interactions with the police have opened up a dialogue about the role of urban police forces within the United States. At the same time, a similar conversation has emerged about Brazil. Recent reports have suggested that people of color within Brazilian cities are twice as likely as white people to be killed by the police. These discourses have facilitated larger political questions about racial biases, the use of force, and the trajectory of urban policing in the modern era.

The current theories and practices behind policing race did not occur in a vacuum. A direct line can be traced back to the early nineteenth century. Modern police theories and practices emerged in relationship to enslaved people within slaveholding cities. As legislators sought to control the enslaved population, they invented justifications for permanent police forces with the power to take action against minor and major crimes. To appreciate this, we need to consider the multiple layers of legislative response to urban growth and enslaved people's actions therein. Most obviously, legislators created statutes that attempted to prevent slave rebellions. Second, they developed and expanded definitions of public order through a criminalization of a number of everyday actions of enslaved people. Slaves had always run away, drunk, gathered, lived with one another, and worked throughout the city, but local authorities placed increasingly emphasis on the need to interrupt and prevent these activities, because they were seen as inherently disruptive actions or precursors for more serious events. Third, local government 
officials needed new and robust police forces to enforce public order crimes and police enslaved people. These legislative movements effectively gave police forces the tools to try to control slaves, free blacks, and working-class immigrants. Over time, local elites grew accustomed to the robust legislation and the police forces. As masters had their slaves arrested, and complied with new taxation and registration laws, they insinuated their acceptance, however qualified, grudging, or unthinking of the police. Although slavery would eventually be abolished and with it the major justification for the invention of urban policing in the first place, municipal authority remained an essential part of urban life. Early nineteenth-century municipal policing formed the root of modern conceptions of race, order, and policing.

The present dissertation suggests a new way of telling the story of policing, order, and slavery in nineteenth-century Atlantic slaveholding cities. As historians have long known, the commercial and demographic growth of cities created opportunities for enslaved people. They used the cityscape to run away, drink, gamble, and gather. Regional and municipal legislators responded with legislation that attempted to discourage these acts. Legislators did so by expanding definitions of public order crimes, which justified a more robust system of surveilling and policing the enslaved population. The police could not entirely stop enslaved people's creative uses of the city, but it became a self-justifying mechanism for the everyday monitoring and disruption of a growing list of criminal conduct, which ultimately expanded well beyond the activities of enslaved people.

My dissertation uses the examples of New Orleans and Salvador to provide insight into the nineteenth-century urban slaveholding Atlantic. While the different 
origins of American and Brazilian jurisprudence, along with their distinctive geopolitical contexts, have dominated discussions and comparisons of slavery in each region, the two cities had much in common. Both of these cities were major urban centers in nations that did not ban slavery until the second half of the nineteenth century. These cities also experienced similar patterns commercial and demographic growth, as each of their economies were tied to sugar production. The legislative and police records of each city indicate that slaves affected the concepts and the procedures that guided policing in the era.

Alongside these fundamental and too often overlooked similarities, of course, several key differences developed. First, each municipality attained a different degree of autonomy. In New Orleans, territorial and state legislators had a minimal impact on the development of municipal ordinances. Regional government officials largely left the New Orleans City Council and New Orleans City Guard to their own devices. However, Salvador's câmara (city council) negotiated larger political currents. As Liberals and Conservatives fought for control of Imperial Brazil, they created two idealized versions of government that vacillated as one party or the other gained control of the Brazilian General Assembly. Liberals pushed local autonomy and, in effect, supported the local rule of the câmara and province in the immediate wake of Brazilian independence (1824). Conservatives consolidated national and provincial bureaucracy around mid1830s. This created two periods of rule in Salvador's câmara. In the first period (1824 1837), the câmara had considerable power. In the second (1838 - after), the Bahian Legislative Assembly and Bahian provincial administrators also established legislation on 
the policing of slavery in Salvador. Yet, the câmara still passed ordinances relating to the policing of slavery.

Second, the records of the police represented two different approaches to policing the urban enslaved population. Arrest patterns in each city varied greatly. In New Orleans, the City Guard initially arrested slaves at high rates. In the 1809 and 1814 Reports of the Captain of the Guards, the City Guard arrested enslaved people at higher rates than their representative percentage of the city's population. The arrest rate was roughly twice as large as the proportional population of enslaved people. However, the rate decreased by 1824 and 1834 . Although the rate was still higher than the population percentage of slaves, the signified that policing other groups became essential to official constructions of order. In Salvador, the government records indicate that the police forces commonly arrested enslaved people at proportions lower than their representative population of the city. While Salvador's enslaved population hovered around $40 \%$ throughout the 1830 s, they accounted for only $24 \%$ and $14 \%$ of the total arrests in 1831 and 1837. In the years after, as the enslaved population decreased, police forces arrested slaves more frequently.

Despite these differences and the unique chronological developments in each period, New Orleans and Salvador experienced three similar periods of changes of policing slavery. The first period (1804 to 1811 in New Orleans and 1824 to 1835 in Salvador) was defined by preliminary attempts for the municipalities to structure themselves and their policing within larger important political changes. In the second period (1811 to 1815 in New Orleans and 1835 to 1838 in Salvador) each city responded to slave rebellions and political instability with laws that circumscribed the actions of 
enslaved people. Legislators and the police also asserted a new authority that assumed some of the rights and responsibilities of slaveownership. Despite putting down slave rebellions and stabilizing the cities, local authorities passed legislation that promoted government oversight in response to the growth of the city and their enslaved populations in the third period (1815 to 1835 in New Orleans and 1838 to 1850 in Salvador). By mid-century, these cities had robust police forces with broad authority.

In the first period of development, officials in New Orleans and Salvador navigated larger demographic, economic, and political events. The Louisiana Purchase (1804) fundamentally influenced New Orleans. The Louisiana Purchase unleashed a westward expansion that facilitated economic development and population increases. These events also influenced political events, as Americans fought for control of political power with Creoles. In this context, enslaved people were an overt part of New Orleans. Both their everyday actions and the ones that threatened public order became a focal point of local administrators. Within the environment, territorial and municipal officials experimented with several different constructions of public order. The City Guard commonly arrested enslaved people for public order crimes and created their own norms of preserving the welfare of New Orleans. Brazilian independence (1821 - 1824) had the same type of impact on Salvador, as the Louisiana Purchase had on New Orleans. While Salvador had experienced commercial and demographic growth in the last years of Portuguese rule, independence impeded some of the growth. Independence also unleashed partisan politics that fluctuated between centralization and local autonomy. The Liberal political party initially won out and promoted local autonomy. These political currents shaped how legislation was created in Salvador, as local institutions 
encouraged public order. Enslaved people responded to the growth of Salvador and seized the various opportunities around them. Although they were not arrested at levels representative of their population, enslaved people were an important focus of local legislative and policing efforts in Salvador. Collectively, officials in New Orleans and Salvador made enslaved people the centerpiece of constructions of public order.

In the second period, New Orleans and Salvador responded to slave rebellions and political instability with stronger policing presences and greater oversight of enslaved populations. The German Coast Rebellion (1811) and the Revolta dos Malês (1835) were important events in New Orleans and Salvador. These slave rebellions proved to local officials that public order was something tenuous. These periods of instability created a moment for enslaved people to participate in activities, ran away and rebelled, that pushed upon conceptions of public order. Government officials in New Orleans and Salvador countered with laws that restricted how enslaved people lived, worked, and recreated. While the New Orleans City Council was responsible for these changes in New Orleans, the Bahian Legislative Assembly and the police chief oversaw these reforms in Salvador. In effect, new systems of public order appeared in each city. Restrictive legislation required strong police to interpret and apply laws. Therefore, local government officials expanded the mandate of police forces to include greater oversight of enslaved and free people of color and masters. The modern theories of municipal oversight emerged from the period.

In the third period, the disorders of the middle period subsided but the theories of public order and policing remained. Although the populations and of enslaved and free people of color decreased in New Orleans and Salvador, the robust and intrusive police 
forces remained. The New Orleans City Council, the Bahian Legislative Assembly, and Salvador's câmara encouraged public order through legislation on enslaved people. In New Orleans, these laws included restrictions on trading, hiring-out, and working enslaved people. In Salvador, the legislation attempted to make enslaved people more visible in the city and its official records. Local police forces responded to these codes and the actions of enslaved people. Police forces responded by arresting enslaved people at proportions more representative of their respective populations.

Collectively, these periods of development and my dissertation highlights an important period in urban policing. The theories and practices that justified public oversight formed in the early nineteenth century. In slaveholding cities, urban policing and public order were both tied to changes in the population of enslaved people. Legislation created new mandates for policing slavery that responded specifically to the urban environment. Policing slavery became a means for local authorities to assert themselves into the everyday lives of inhabitants of New Orleans and Salvador. 


\begin{abstract}
APPENDIX
The information contained in the appendix serves as a supplement to the tables within the dissertation. The tables in the appendix provide more complete account of the different occupations and crimes of enslaved people than the tables within the body of the dissertation.

Table 2.A. Occupations of Slaves within the Inventories of New Orleans between 1803 and 1840

The current chart serves as a complete list of the occupations of slaves compiled from 295 of the 3,329 total inventories in Orleans Parish Civil Court between 1803 and 1840. In these inventories, officials listed that 337 slaves performed 528 jobs. The table is arranged in descending number of workers in each occupation. As Table 2 in the dissertation had indicated, Table 2.A. shows that slaves predominantly worked in domestic occupations. The first four rows-Cook, Washer, Domestic, and House Servant - are all domestic occupations. Those specific occupations collectively outnumbered all other occupations listed for slaves.
\end{abstract}




\begin{tabular}{|l|r|l|r|}
\hline & Number & Occupations & Number \\
\hline Cocupations & 87 & Turner & 3 \\
\hline Washer & 82 & Plasterer & 3 \\
\hline Domestic & 65 & Sailor & 2 \\
\hline House Servant & 61 & Joiner & 2 \\
\hline Pickaxe & 23 & Apprentice Shoemaker & 2 \\
\hline Drayman & 22 & Milk Seller & 2 \\
\hline Ironer & 22 & Sugarmaker & 1 \\
\hline Woodcutter & 19 & Saddler & 1 \\
\hline Laborer & 16 & Biscuitmaker & 1 \\
\hline Bricklayer & 14 & Caulker & 1 \\
\hline Nanny & 12 & Milker & 1 \\
\hline Tradesperson & 12 & Bellinger & 1 \\
\hline Fieldhand & 11 & Pilot & 1 \\
\hline Coachman & 9 & Boy & 1 \\
\hline Seamstress & 9 & Hatter & 1 \\
\hline Shoemaker & 6 & Chocolate Maker & 1 \\
\hline Gardener & 5 & Molder & 1 \\
\hline Commander & 5 & Apprentice Joiner & 1 \\
\hline Carpenter & 4 & Waiter & 1 \\
\hline Servant & 4 & Butcher & 1 \\
\hline Mason & 4 & Journeyman & 1 \\
\hline Day Laborer & 3 & Wax Molder & 1 \\
\hline Cowherd & 3 & Total & 528 \\
\hline & & & \\
\hline & & & \\
\hline
\end{tabular}

Source: "Estate Inventories, 1803 - 1877," Orleans Parish Civil Court, Louisiana Division, New Orleans Public Library, New Orleans, Louisiana. 
Table 3.A. Arrest Records of slaves from the Reports of the Captain of the Guards [New Orleans] in 1809

The current chart serves as a complete list of the crimes for which the City Guard arrested slaves for in 1809. Records for the Reports of the Captain of the Guards were very limited in 1809; there were five days of reports in December amongst the Charles F. Heartman Collection. In the sample, the City Guard reported that slaves account for 7 of the 11 total arrests. Like Table 3: Arrest Records from the Reports of the Captain of the Guards in 1809, Table 3.A. suggests that enslaved people were commonly arrested for property and public order crimes. The City Guard did not arrest a single enslaved person for a violent crime.

\begin{tabular}{|l|r|r|}
\hline Crimes & Slaves & \\
\hline Stealing & 2 & $29 \%$ \\
\hline Maroonage & 2 & $29 \%$ \\
\hline $\begin{array}{l}\text { Using False } \\
\text { Monies }\end{array}$ & 1 & $14 \%$ \\
\hline Found Sleeping & 1 & $14 \%$ \\
\hline $\begin{array}{l}\text { Illegally Selling } \\
\text { Goods }\end{array}$ & 1 & $14 \%$ \\
\hline Total & 7 & \\
\hline
\end{tabular}

Source: "Report of the Captain of the Guards," Charles F. Heartman Collection 1724 1897 (Suite 319, Building 38, Xavier University of Louisiana, 1 Drexel Drive, New Orleans, LA 70125, 1809). 
Table 4.A. Occupations of Slaves within the Inventories of Salvador between 1800 and 1840

The current chart serves as a complete list of the occupations of enslaved people compiled from 251 of the 1,381 total inventories in Salvador between 1800 and 1840. In these inventories, officials listed that 1202 slaves performed 1365 jobs. As Table 4 in the dissertation had indicated, Table 4.A. shows that slaves predominantly worked in domestic occupations. Enslaved people most commonly labored as house servants in the city.

\begin{tabular}{|c|c|c|c|}
\hline Occupations & Number & Occupations & Number \\
\hline House Servant & 197 & Iron Hammerer & 3 \\
\hline Domestic & 132 & Shopkeeper/Clerk & 4 \\
\hline $\begin{array}{l}\text { Carregador do } \\
\text { Cadeira/Sedan Carrier }\end{array}$ & 118 & Cooper & 3 \\
\hline Cook & 102 & Works for Ship owner & 3 \\
\hline Farmhand & 94 & Hairdresser & 3 \\
\hline Pickaxe & 93 & Boy & 2 \\
\hline Washer & 66 & Fabric Seller & 2 \\
\hline Seamstress & 66 & Copper Worker & 2 \\
\hline Ganhador/Day Laborer & 64 & Boiler worker & 2 \\
\hline Teamaker & 33 & Blacksmith & 2 \\
\hline Ironer & 33 & Salt Warehouse Worker & 2 \\
\hline Mason & 32 & Locksmith & 2 \\
\hline Carpenter & 28 & Coppersmith & 2 \\
\hline Shoemaker & 28 & Cashier & 1 \\
\hline Service of the Customs & 26 & Fugitive & 1 \\
\hline Farmer/Farmworker & 25 & Coffee Grinder & 1 \\
\hline Lacemaker & 22 & $\begin{array}{l}\text { Servico do Mar/Service } \\
\text { of the Sea }\end{array}$ & 1 \\
\hline Sailor & 21 & Vegetable Seller & 1 \\
\hline Tailor & 20 & Boilermaker & 1 \\
\hline $\begin{array}{l}\text { Servico da Rua/Service } \\
\text { of the Street/Day } \\
\text { Laborer }\end{array}$ & 17 & Rondiera/Patrolman & 2 \\
\hline
\end{tabular}




\begin{tabular}{|l|r|l|r|} 
Sugar Mill & 13 & Worker & 1 \\
\hline Tobacco Roller & 10 & $\begin{array}{l}\text { Service of the Sugar } \\
\text { Fill }\end{array}$ & 1 \\
\hline Framer & 9 & Painter & 1 \\
\hline Rigger & 7 & Boiler Worker & 1 \\
\hline $\begin{array}{l}\text { Lime (Chalk) } \\
\text { Transporter }\end{array}$ & 6 & Soldier & 1 \\
\hline Marketseller & 6 & Rifleman & 1 \\
\hline Sailing Boat & 6 & Servant & 1 \\
\hline Caulker & 6 & Turner & 1 \\
\hline Police & 6 & Tinsmith & 1 \\
\hline Barber & 5 & Minter & 1 \\
\hline Fisherman & 4 & Healer & 1 \\
\hline Sugar Cane & 4 & Shellfisherman & 1 \\
\hline Tabacco Tamper & 4 & Sugarmill Worker & 1 \\
\hline Coachman & 3 & Goldsmith & 1 \\
\hline Sugar Roller & 3 & Ploughman & 1 \\
\hline Breadmaker & 3 & Total & 1367 \\
\hline
\end{tabular}

Source: “Inventários Da Captial (1800 - 1888)." Seção Judiciária. Arquivos Do Estado Do Bahia. Salvador, BA. 
Table 5.A. Slave arrests in the record of the Juiz da Paz, Conceição da Praia, "Relação do Prezos", September - October 1831

The current chart serves as a complete record of slave arrests listed in the records of the Juiz da Paz in Conceição da Praia in September and October of 1831. Records of these two months were the only records of the Juiz da Paz prior to 1835 found amongst the records of the Arquivos Do Estado Do Bahia. Of the 46 recorded actions, only 38 had clearly identifiable status and crimes. Of the 38 records, the Juiz da Paz reported 11 arrests, punishment, or release of enslaved people for specific crimes. Like Table 5: Juiz da Paz, Conceição da Praia, "Relação do Prezos", September - October 1831, Table 5.A. suggests that slaves were arrested for public order crimes most frequently. In these records, officials brought slaves before the Juiz da Paz for four specific crimes, twomaroonage and being part of a maroon community — of which were public order crimes.

\begin{tabular}{|l|r|r|}
\hline Crime/Translation & Slave & \\
\hline Maroonage/Running Away & 4 & $36 \%$ \\
\hline Furto/Theft & 4 & $36 \%$ \\
\hline Injuring another & 1 & $9 \%$ \\
\hline $\begin{array}{l}\text { Quilombos/Part of a Maroon } \\
\text { Colony }\end{array}$ & 2 & $18 \%$ \\
\hline Total & 11 & \\
\hline
\end{tabular}

Sources: Suixaz, João Lourenço. João Lourenço Suixaz to Prezidente do Provincia. Juizes de Paz 1 Vara. Arquivos Do Estado Do Bahia. Salvador, BA, 1831; Suixaz, João Lourenço. João Lourenço Suixaz to Prezidente do Provincia. Juizes de Paz 1 Vara. Arquivos Do Estado Do Bahia. Salvador, BA, 1831. 
Table 6.A. Arrest Records of slaves from the Reports of the Captain of the Guards [New Orleans] in 1814

The current chart serves as a complete record of slave arrests from a random sampling of 241 records of the 663 actions in the Reports of the Captain of the Guards from January to November of 1814 . Of the 241 records, 82 clearly stated that enslaved people committed specific crimes. Like Table 6: The sample of the Reports of the Captain of the Guards in 1814, Table 6.A. suggests that the City Guard most commonly arrested enslaved people for crimes against public order. Amongst the records, maroonage was the most frequent arrest.

\begin{tabular}{|c|c|c|c|c|c|}
\hline & $\begin{array}{c}\text { Slaves } \\
\text { Arrested }\end{array}$ & & & $\begin{array}{l}\text { Slaves } \\
\text { Arrested }\end{array}$ & \\
\hline Maroonage & 32 & $39 \%$ & $\begin{array}{l}\text { Forming and Illegal } \\
\text { Society }\end{array}$ & 2 & $2 \%$ \\
\hline Stealing & 12 & $15 \%$ & $\begin{array}{l}\text { Disturbing the } \\
\text { Peace }\end{array}$ & 1 & $1 \%$ \\
\hline Trespassing & 8 & $10 \%$ & $\begin{array}{l}\text { Pris de } \\
\text { Boisson/Drunkeness }\end{array}$ & 1 & $1 \%$ \\
\hline Fighting & 4 & $5 \%$ & Stabbing & 1 & $1 \%$ \\
\hline Dancing & 4 & $5 \%$ & $\begin{array}{l}\text { Illegal emptying of } \\
\text { a canister }\end{array}$ & 1 & $1 \%$ \\
\hline Found Sleeping & 3 & $4 \%$ & Vagabondage & 1 & $1 \%$ \\
\hline Insolence & 2 & $2 \%$ & Dressing as a Man & 1 & $1 \%$ \\
\hline $\begin{array}{l}\text { Trying to hop a } \\
\text { ttrain }\end{array}$ & 2 & $2 \%$ & Using False Monies & 1 & $1 \%$ \\
\hline Playing Cards & 2 & $2 \%$ & Begging & 1 & $1 \%$ \\
\hline $\begin{array}{l}\text { Illegally Selling } \\
\text { Goods }\end{array}$ & 2 & $2 \%$ & $\begin{array}{l}\text { Failure to Complete } \\
\text { Service }\end{array}$ & 1 & $1 \%$ \\
\hline \multicolumn{4}{|l|}{ Total } & \multicolumn{2}{|l|}{82} \\
\hline
\end{tabular}

Source: "Report of the Captain of the Guards." Charles F. Heartman Collection 1724 1897. Suite 319, Building 38, Xavier University of Louisiana, 1 Drexel Drive, New Orleans, LA 70125. 
Table 8.A. Total Arrests of slaves reported at São Bento [January - November 6, 1837] The current table is a complete record of the Policia arrests of slaves from a random sampling of the 277 of the 1088 total actions recorded by the Policia between January and November 6, 1837. São Bento was a neighborhood in Salvador's Cidade Alta. Of the 277 records, there were 282 arrests listed with specific status. Of the 282 arrest records, the Policia arrested 37 slaves. Like Table 8: Total Arrests reported at São Bento [January - November 6,1837], Table 8.A. indicates that the Policia most commonly arrested enslaved people for public order crimes. Running away made up a larger percentage of the total arrests than all other crimes.

\begin{tabular}{|l|r|r|}
\hline Crime & $\begin{array}{r}\text { Slaves } \\
\text { Arrested }\end{array}$ & \\
\hline Fugido/Running Away & 21 & $57 \%$ \\
\hline Dizordem/Disorder & 3 & $8 \%$ \\
\hline Roubo/Robbery & 3 & $8 \%$ \\
\hline $\begin{array}{l}\text { Edital 20 do } \\
\text { Fevereiro/Curfew, Pass, or } \\
\text { Illegal Gathering }\end{array}$ & 2 & $5 \%$ \\
\hline Suspiciousness & 2 & $5 \%$ \\
\hline Found Out late & 2 & $5 \%$ \\
\hline Questioning & 1 & $3 \%$ \\
\hline Injured & 1 & $3 \%$ \\
\hline Vagabondage & 1 & $3 \%$ \\
\hline Furto/Theft & 1 & $3 \%$ \\
\hline Total & 37 & \\
\hline
\end{tabular}

Source: "Parte Geral Da Guarda Policial.” Mapas Diários. Maço 3059, Maço 6301. Guarda Urbana, Correspondencia recebida da Guarda Policial (1832 - 1839). Salvador, BR: Arquivo Público do Estado da Bahia.

Table 9.A. Arrest Records of slaves from the Reports of the Captain of the Guards [New Orleans] in 1824 
The current charts serves as a complete record of slaves in a random sampling of 318 of 1986 arrest records in the Reports of the Captain of the Guards from January through December 1824. Of the 318 arrest records, 225 had clearly identifiable status and crimes. The City Guard arrested enslaved people for 78 total crimes. Like Table 9: The Sample of the Reports of the Captain of the Guards in 1824, Table 9.A. suggests that the City Guard most commonly arrested enslaved people for crimes against public order. Of the 19 different crimes listed, 14 were public order crimes. Maroonage was the most common listed reason for arresting slaves.

\begin{tabular}{|l|r|r|}
\hline Crime & $\begin{array}{l}\text { Slaves } \\
\text { Arrested }\end{array}$ & \\
\hline Maroonage & 25 & $32.05 \%$ \\
\hline Found Sleeping & 14 & $17.95 \%$ \\
\hline Stealing & 10 & $12.82 \%$ \\
\hline $\begin{array}{l}\text { Sur la Levee/Found on the } \\
\text { Levee }\end{array}$ & 7 & $8.97 \%$ \\
\hline Disposition & 5 & $6.41 \%$ \\
\hline Pris de Boisson/Drunkeness & 2 & $2.56 \%$ \\
\hline Illegal emptying of a canister & 2 & $2.56 \%$ \\
\hline Suspicion of Maroonage & 2 & $2.56 \%$ \\
\hline Without Pass & 1 & $1.28 \%$ \\
\hline Gambling & 1 & $1.28 \%$ \\
\hline Disturbing the Peace & 1 & $1.28 \%$ \\
\hline Battered & 1 & $1.28 \%$ \\
\hline Poor Treatment & 1 & $1.28 \%$ \\
\hline Insolence & 1 & $1.28 \%$ \\
\hline Trespassing & 1 & $1.28 \%$ \\
\hline Climbing Stuff & 1 & $1.28 \%$ \\
\hline Misweighing & 1 & $1.28 \%$ \\
\hline Firing a gun & 1 & $1.28 \%$ \\
\hline Attempted Stabbing & 1 & $1.28 \%$ \\
\hline Total & 78 & \\
\hline
\end{tabular}


Source: "Report of the Captain of the Guards," Charles F. Heartman Collection 1724 1897 (Suite 319, Building 38, Xavier University of Louisiana, 1 Drexel Drive, New Orleans, LA 70125, 1824). 
Table 10.A. 1834 Arrest Records of Slaves from the Reports of the Captain of the Guards in New Orleans

The current table serves as a complete list of the crimes that the City Guard arrested slaves for amongst a random sampling of 360 of the 6,134 total reported police actions in New Orleans in 1834. Of the 360 records, 204 had clearly identifiable status and crime. The City Guard reported slaves being arrested for 62 crimes. Like Table 10: The Sample of the Reports of the Captain of the Guards in 1834, Table 10.A. indicates that crimes against public order remained the predominant category of arrests for slaves. The first three listed crimes — maroonage, found sleeping, and dancing — were all crimes against public order and accounted for $63 \%$ of all arrests in the sample of that year.

\begin{tabular}{|l|r|r|}
\hline & Slaves & \\
\hline Maroonage & 17 & $27 \%$ \\
\hline Found Sleeping & 12 & $19 \%$ \\
\hline Dancing & 10 & $16 \%$ \\
\hline Stealing & 9 & $15 \%$ \\
\hline Escaping the Chains & 2 & $3 \%$ \\
\hline Carrying a Knife/Illegal & 2 & $3 \%$ \\
Weapon & 2 & $3 \%$ \\
\hline Unknown & 1 & $2 \%$ \\
\hline Suspicious & 1 & $2 \%$ \\
\hline Without Pass & 1 & $2 \%$ \\
\hline Insolence & 1 & $2 \%$ \\
\hline Illegal Attendance of Ball & 1 & $2 \%$ \\
\hline Fighting & 1 & $2 \%$ \\
\hline Using False Monies & 1 & $2 \%$ \\
\hline Complaint against them & 1 & $2 \%$ \\
\hline Arson & 62 & \\
\hline Total & &
\end{tabular}

Source: "Report of the Captain of the Guards," Jan - Mar, Louisiana Division/City Archives (New Orleans Public Library, 219 Loyola Ave., New Orleans, LA 70112, 
1834); "Report of the Captain of the Guards," April - May, Louisiana Division/City Archives (New Orleans Public Library, 219 Loyola Ave., New Orleans, LA 70112, 1834); "Report of the Captain of the Guards," Jun - Dec, Louisiana Division/City

Archives (New Orleans Public Library, 219 Loyola Ave., New Orleans, LA 70112, 1834) 
Table 13.A. Crime statistics of slaves within a sample of the Registro de Portaria from January to December 1847

The current chart is a complete list of the arrests of enslaved people in a random sampling of 267 of the total 863 Policia actions recorded from January to December of 1847. While the Policia arrested slaves 40 times amongst the random sample, only 14 indicate specific crimes. Like Table 13: Crime statistics within a sample of the Registro de Portaria from January to December 1847, Table 13.A. indicates that the Policia most commonly arrested slaves for crimes against public order. Moreover, running away remained a major concern for police officials in Salvador, making up $86 \%$ of all arrests of slaves in the sample.

\begin{tabular}{|l|r|r|}
\hline Crime & \multicolumn{1}{|c|}{$\begin{array}{c}\text { Slave } \\
\text { Arrested }\end{array}$} & \\
\hline $\begin{array}{l}\text { Edital 20 do } \\
\text { Fevereiro/Curfew, Pass, or } \\
\text { Illegal Gathering }\end{array}$ & 1 & $7 \%$ \\
\hline Running Away & 12 & $86 \%$ \\
\hline Furto/Stealing & 1 & $7 \%$ \\
\hline & 14 & \\
\hline
\end{tabular}

Source: Registro de Portarias (1847 - 1849), Maço 5622, Policia (Salvador, BR: Arquivo Público do Estado da Bahia, 1847). 
Bibliography

Abé-Lallement, Robert. Reise Durch Nord=Brasilien Im Jahier 1859. Leipzig: F.D. Bradhaus, 1860.

Acts Passed at the First Session of the First Legislature of the Territory of New Orleans: Begun and Held in the City of New Orleans, on the 25th Day of January, in the Year of Our Lord One Thousand Eight Hundred and Six, and of the Independence of the United States of America the Thirtieth. New Orleans, LA: The Authority, 1807.

Adler, Jeffrey. "Streetwalkers, Degraded Outcasts, and Good-for-Nothing Huzzies: Women and the Dangerous Class in Antebellum St. Louis." The Journal of Social History 25, no. 4 (1992): $737-55$

Africa and the Americas: Interconnections During the Slave Trade. Edited by José C. Curto and Reneé Soulodre-La France. Trenton, NJ: Africa World Press, 2005.

Algranti, Leila Mezan. "Slave Crimes: The Use of Police Power to Control the Slave Population of Rio de Janeiro.” Luso-Brazilian Review 25, no. 1 (1988): 27 - 48.

Andrade, Maria José de Souza. A Mão de Obra Escrava Em Salvador 1811 - 1860. São Paulo, SP: Corrupio, 1988.

Andrews, George Reid. Afro-Latin America, 1800 - 2000. New York, NY: Oxford University Press, 2004.

“Application; Negro; Enquired; Necessary; Submissive; Bayon; Mr. Milns; Enough." L'Abeille, 24 March 1830, 5.

Arquivo Minicipal de Salvador. Repertório de Fontes Sobre a Escravidão Existentes No Arquivo Municipal de Salvador as Posturas. Salvador, Bahia, Brazil: Fundação Gregório de Mattos, Prefeitura Municipal do Salvador, 1988.

Aufderheide, Patricia Ann. "Order and Violence: Social Deviance and Control in Brazil, 1780 - 1840.” Ph.D. diss. Minneapolis, MN: University of Minnesota, 1976.

Baade, Hans W. "The Law of Slavery in Spanish Luisiana 1769 - 1803.” In Louisiana's Legal Heritage, Edward F. Hass, 45 - 86. Pensacola, FL: Louisiana Historical Society, 1983.

Bahia. "N. 1. Lei de 28 de Março de 1835." In Collecção Da Leis e Resoluções Da Assemblea Legislativa Da Bahia, Sanccionadas e Publicadas Nos Annos de 1835 a 1838. Vol 1. Salvador, BA: Typ. Constitutional de França Guerra, 1863. . “N. 14. Lei de 2 de Junho de 1835.” In Collecção Da Leis e Resoluções Da Assemblea Legislativa Da Bahia, Sanccionadas e Publicadas Nos Annos de 1835 a 1838. Vol 1. Salvador, BA: Typ. Constitutional de França Guerra, 1863. 
. “N. 273. Lei de 23 Maio de 1847." In Collecção Da Leis e Resoluções Da Assemblea Legislativa Da Bahia, Sanccionadas e Publicadas Nos Annos de 1842 a 1847. Vol 3., 358 - 61. Salvador, BA: Typ. Constitutional de França Guerra, 1863.

. “N. 74. Lei de 15 de Junho de 1838.” In Collecção Da Leis e Resoluções Da Assemblea Legislativa Da Bahia, Sanccionadas e Publicadas Nos Annos de 1835 a 1838. Vol 1. Salvador, BA: Typ. Constitutional de França Guerra, 1863.

. “N. 9. Lei de 13 de Maio de 1835." In Collecção Da Leis e Resoluções Da Assemblea Legislativa Da Bahia, Sanccionadas e Publicadas Nos Annos de 1835 a 1838. Vol 1. Salvador, BA: Typ. Constitutional de França Guerra, 1863.

. "Regulamento para a Formação de Capatasias, Em Formidade Da Lei d'Assembléa Legislativa Provincial de 2 de Junho Do Anno Passado, Sob n. 14." In Collecção Da Leis e Resoluções Da Assemblea Legislativa Da Bahia, Sanccionadas e Publicadas Nos Annos de 1835 a 1838. Vol 1. Salvador, BA: Typ. Constitutional de França Guerra, 1863.

Baptist, Edward E. 2001. “'Cuffy,' 'Fancy Maids,' and 'One-Eyed Men': Rape, Commodification, and the Domestic Slave Trade in the United States." The American Historical Review 106, no. 5 (December 2001): 1619 - 50.

Barickman, B.J. Bahian Counterpoint: Sugar, Tobacco, and Slavery in the Recôncavo. Stanford, CA: Stanfored University Press, 1998.

Barman, Roderick. Brazil: The Forging of a Nation, 1798 - 1852. Stanford, CA: Stanford University Press, 1988.

Boritch, Helen, and John Hagan. "Crime and the Changing Forms of Class Control: Policing Public Order in 'Toronto the Good'." Social Forces 66, no. 2 (December 1987): 307 - 55.

Brazil, Etienne Ignace. “A Revolta Dos Malês.” Revista Do Instituto Geográfico e Histórico Da Bahia, no. 33 (1907): 129 - 49.

Brazil, Padre Etienne Ignace. “A Revolta Dos Malês.” Revista Do Instituto Histórico e Geográfíco Da Bahia 72 (1909): 67 - 126.

Brazil. Collecção Da Leis Do Imperio Do Brazil. Vol 1. Leis das Cortes Geraes Extraordinarias e Constituintes Da Portugueza. Rio de Janeiro, RJ: Imprensa Nacional, 1822.

Brown, Alexandra K. “'A Black Mark on Our Legislation': Slavery, Punishment, and the Politics of Death in Nineteenth-Century Brazil." Luso-Brazilian Review 37, no. 2 (Winter 2000): 95 - 121.

."'On the Vanguard of Civilization': Slavery, the Police, and Conflicts Between Public and Private Power in Salvador Da Bahia, Brazil, 1835 - 1888." Ph.D. diss. Austin, TX: University of Texas, 1998. 
"Cabarets; Impunity; Police; Owner; Offence; Wise." The Daily Picayune, 15 June $1839,2$.

Chaloub, Sidney. Visões Da Liberdade: Uma História Das Últimas Décadas Da Escravidão Na Corte. São Paulo, SP: Companhia Das Letras, 1990.

Claiborne, W.C.C. "Answer: Claiborne to General Lambert." In The Letter Books of William C.C. Claiborne, 1801 - 1816. Vol. 6, edited by Dunbar Rowland, 353 54. Jackson, MS: Mississippi State Library and Archive, 1917.

_. "Circular. New-Orleans." Early American Imprints Series 2, no. no. 6965 (8 November 1804). America's Historical Imprints.

. "Claiborne to Brown, 27 July 1813." In The Letter Books of William C.C. Claiborne, 1801 - 1816. Vol. 6, edited by Dunbar Rowland, 245 - 46. Jackson, MS: Mississippi State Library and Archive, 1917.

."Claiborne to Casa Calvo." In The Letter Books of William C.C. Claiborne, 1801 - 1816. Vol. 2, edited by Dunbar Rowland, 382 - 83. Jackson, MS: Mississippi State Library and Archive, 1917.

- "Claiborne to Choctaw Chief, August 1812." In The Letter Books of William C.C. Claiborne, 1801 - 1816. Vol. 6, edited by Dunbar Rowland, 153 - 55. Jackson, MS: Mississippi State Library and Archive, 1917.

- "Claiborne to General Lambert." In The Letter Books of William C.C. Claiborne, 1801 - 1816. Vol. 6, edited by Dunbar Rowland, 352 - 53. Jackson, MS:

Mississippi State Library and Archive, 1917.

" "Governor Claiborne to Jackson." In Correspondences of Andrew Jackson.

Vol. II: May 1, 1814 to December 31, 1819, edited by John Spencer Bassett, 55 56. Washington, D.C.: Carnegie Institution of Washington, 1814.

Claiborne, W.C.C. "Governor Claiborne to Jackson." In Correspondences of Andrew Jackson. Vol. II: May 1, 1814 to December 31, 1819, edited by John Spencer Bassett, 159 - 61. Washington, D.C.: Carnegie Institution of Washington, 1815.

Claiborne, W.C.C. "James Madison From William C.C. Claiborne, 15 July 1804 (Abstract)." Source: The Papers of James Madison, Secretary of State Series, vol. 7, 2 April-31 August 1804, ed. David B. Mattern, J.C. A. Stagg, Ellen J. Barber, Anne Mandeville Colony, Angela Kreider, and Jeanne Kerr Cross. Charlottesville: University of Virginia Press, 2005, p. 457. Founders Online, National Archives.

. "Ordinance Regulating the City Police." In The Letter Books of William C.C. Claiborne, 1801 - 1816. Vol. 2, edited by Dunbar Rowland, 16 - 19. Jackson, MS: Mississippi State Library and Archive, 1917.

"Connecticut; New Orleans; Prohibited." The Daily Picayune, 23 June 1838, 2.

Costa, Emilia Viotti da Costa. The Brazilian Empire: Myths and Histories. The University of North Carolina Press: Chapel Hill, NC, 2000. 
Cottrol, Robert J. The Long, Lingering Shadow: Slavery, Race, and Law in the American Hemisphere. Athens, GA: University of Georgia Press, 2013.

Crété, Liliane. Daily Life in Louisiana, 1815 - 1830. Patrick Gregory. Baton Rouge, LA: Louisiana State University Press, 1978.

Dargo, George. Jefferson's Louisiana: Politics and the Clash of Legal Traditions. Cambridge, MA: Harvard University Press, 1975.

Dawdy, Shannon Lee. Building the Devil's Empire: French Colonial New Orleans. Chicago, IL: The University of Chicago Press, 2008.

de Casal, Manuel Aires. Corografia Brasílica, Ou Relação Histórico-Geográfica Do Reino Do Brasil. Rio De Janiero, RDJ: Impressão Régia; Edições Cultura;, 1817.

De La Fuente, Alejandro. "Slave Law and Claims-Making in Cuba: The Tannenbaum Debate Revisited." Law and History Review 22, no. 2 (Summer 2004): 339 - 69.

Degler, Carl N. Neither Black Nor White: Slavery and Race Relations in Brazil and the United States. New York, NY: Macmillan, 1971.

Delson, Roberta. "Land and Urban Planning: Aspects of Modernization in Early Nineteenth-Century Brazil.” Luso-Brazilian Review 16, no. 2 (Winter 1979): 191 $-214$.

Despatches from the United States Consuls in Pernambuco, 1817 - 1906. Washington, DC: National Archives and Records Service, 1962.

Dessens, Nathalie. Creole City: A Chronicle of Early American New Orleans. Gainesville, FL: University of Florida Press, 2015.

Din, Gilbert C. Spaniards, Planters, and Slaves: The Spanish Regulation of Slavery in Louisiana, 1763 - 1803. College Station, TX: Texas A \& M University Press, 1999.

Doctor Rarcarn. “Correspondence.” Report. Charles F. Heartman Collection 1724 - 1897. Suite 319, Building 38, Xavier University of Louisiana, 1 Drexel Drive, New Orleans, LA 70125, 1822.

Donaldson, Gary A. "A Window on Slave Culture: Dances at Congo Square in New Orleans, 1800 - 1862." The Journal of Negro History 69, no. 2 (Spring 1984): 63 72.

Dormon, James H. "The Persistent Specter: Slave Rebellion in Territorial Louisiana." Louisiana History 18, no. 4 (Autumn 1977): 389 - 404.

Duncan, Julian Smith. Public and Private Operation of Railways in Brazil. New York City, NY, 1932.

Dutillet, C. "Rapport Du Lieutenant de la Garde Serve Du 4 Au 5 Juillet 1824." Charles F. Heartman Collection 1724 - 1897. Suite 319, Building 38, Xavier University of Louisiana, 1 Drexel Drive, New Orleans, LA 70125, 1824. 
Earle, W.R.D. “Correspondence.” W.R.D. Earle to James Mather, mayor of New Orleans. Charles F. Heartman Collection 1724 - 1897. Suite 319, Building 38, Xavier University of Louisiana, 1 Drexel Drive, New Orleans, LA 70125, 1808.

Eltis, David. Economic Growth and the Ending of the Transatlantic Slave Trade. Oxford, UK: Oxford University Press, 1987.

“Estate Inventories, 1803 - 1877." Orleans Parish Civil Court. Louisiana Division. New Orleans Public Library.

Evans, Freddi Williams. Congo Square: African Roots in New Orleans. Lafayette, LA: University of Louisiana at Lafayette Press, 2011.

Filho, Walter Fraga. Mendigos, Moleques e Vadios Na Bahia Do Século XIX. Salvador, BA: Editora da Universidade Federal da Bahia, 1996.

Flory, Thomas. Judge and Jury in Imperial Brazil, 1808 - 1871. Austin, TX: University of Texas Press, 1981.

Follett, Richard. The Sugar Masters: Planters and Slaves in Louisiana's Cane World, 1820 - 1860. Baton Rouge, LA: Louisiana State University Press, 2005.

Foucault, Michel. Discipline and Punish: The Birth of the Prison. Translated from the French by Alan Sheridan. London, UK: Allen Lane, 1977.

French, B.F. Historical Collections of Louisiana, Embracing Translations of Many Rare and Valuable Documents Relating to the Natural, Civil and Political History of the State. Compiled with Historical and Biographical Notes, and an Introduction. New York, NY, 1851.

Fundação Cultural do Estado da Bahia. Legislação Provincial Da Bahia Sobre o Negro, 1835 - 1888. Salvador, BA: Fundação Cultural do Estado da Bahia, 1996.

Gibson, J. Gibson's Guide and Directory of the State of Louisiana, and the Cities of New Orleans and Lafayette. New Orleans, LA: J. Gibson, 1838.

Goldin, Claudia Dale. Urban Slavery in the American South 1820 - 1860: A Quantitative History. Chicago, IL: The University of Chicago Press, 1976.

Graden, Dale Torston. “An Act 'Even of Public Security': Slave Resistance, Social Tensions, and the End of the International Slave Trade." The Hispanic American Historical Review 76, no. 2 (May 1996): 249 - 82.

From Slavery to Freedom in Brazil: Bahia, 1835 - 1900. Albuquerque, NM: University of New Mexico Press, 2006.

. "The City Has Too Many Slaves Joined Together': The Abolitionist Crisis in Salvador, Bahia, Brazil, 1848 - 1856.” In The African Diaspora, Alusine Jallah and Stephen E. Maizlish, 134 - 52. College Station, 1996.

Graham, Maria Dundas. Journal of A Voyage to Brazil, and Residence There, During Part of the Years 1821, 1822, 1823. New York, NY: Frederick A. Praeger, 1969. 
Graham, Richard. “Another Middle Passage? The Internal Slave Trade in Brazil.” In The Chattel Principle: Internal Slave Trades in the Americas, edited by Walter Johnson, 291 - 324. New Haven, CT: Yale University Press, 2004.

- Feeding the City: From Street Market to Liberal Reform in Salvador, Brazil, 1780 - 1860. Austin, TX: University of Texas Press, 2010.

—_ "Nos Tumbeiros Mais Uma Vez? O Comércio Interprovincial de Escravos No Brasil.” Afro-Ásia 27 (2002): 121 - 60.

Graham, Richard. Patronage and Politics in Nineteenth-Century Brazil. Stanford, CA: Stanford University Press, 1990.

Gross, Ariela, and Alejandro De la Feunte. "Slaves, Free Blacks, and Race in the Legal Regimes of Cuba, Louisiana, and Virginia: A Comparison." North Carolina Law Review 91, no. 5 (2013): 1699 - 756.

Hadden, Sally E. Slave Patrols: Law and Violence in Virginia and the Carolinas. Cambridge, MA: Harvard University Press, 2003.

Hall, Gwendolyn Midlo. Africans in Colonial Louisiana: The Development of AfroCreole Culture in the Eighteenth Century. Baton Rouge, LA: Louisiana State University Press, 2000.

Hanger, Kimberly S. Bounded Lives, Free Black Society in Colonial New Orleans, 1769 1803. Durham, NC: Duke University Press, 1997.

Harkins, John Edwards. "The Neglected Phase of Louisiana's Colonial History: The New Orleans Cabildo, 1769 - 1803." Phd Dissertation. Memphis, TN: Memphis State University, 1976.

Holloway, Thomas H. Policing Rio de Janeiro: Repression and Resistance in a 19thCentury City. Stanford, CA: Stanford University Press, 1993.

Holmes, Jack D. L. "The Abortive Slave Revolt at Pointe Coupée, Louisiana, 1795." Louisiana History 11, no. 4 (1970): 341 - 62.

Holmes. "Holmes to Wilkinson, 7 September 1812." In The Territorial Papers of the United States. Vol. 6, edited by Clarence Edward Carter, 320 - 21. Washington, D.C.: U.S. Government Printing Office, 1934.

Ingersoll, Thomas N. Mammon and Manon in Early New Orleans: The First Slave Society in the Deep South, 1718 - 1819. Knoxville, TN: University of Tennessee Press, 1999.

"Insurrection in Orleans. Extract of a Letter from a Gentleman in New Orleans to His Friend in Chester, Pennsylvania." Columbian 407 (21 February 1811): 3.

“Inventários Da Captial (1800 - 1888)." Seção Judiciária. Arquivos Do Estado Do Bahia. Salvador, BA. 
Johnson, Jerah. “New Orlean's Congo Square: An Urban Setting for Early AfroAmerican Culture Formation.” Louisiana History 32 (Spring 1991): 117 - 57.

Johnson, Ronald Angelo. Diplomacy in Black and White: John Adams, Toussaint Louverture, and Their Atlantic World Alliance. Race in the Atlantic World 1700 1900. The University of Georgia Press, 2014.

Johnson, Walter. River of Dark Dreams: Slavery and Empire in the Cotton Kingdom. Cambridge, MA: The Belknap Press of Harvard University Press, 2013.

Soul by Soul: Life Inside the Antebellum Slave Market. Cambridge, MA: Harvard University Press, 1999.

Kastor, Peter J. The Nation's Crucible: The Louisiana Purchase and the Creation of America. New Haven, CT: Yale University Press, 2004.

Kerr, Derek. Petty Felony, Slave Defiance, and Frontier Villainy: Crime and Criminal Justice in Spanish Louisiana, 1770 - 1803. New York, NY: Garland Publishers, 1993.

Kidder, Daniel P. Sketches of Residence and Travels in Brazil: Embracing Historical and Geographical Notices of the Empire and Several Provinces. Philadelphia, PA: Sorin \& Ball, 1845.

Klein, Herbert S. "The Internal Slave Trade in Ninenteenth-Century Brazil: A Study of Slave Importations Into Rio de Janeiro in 1852." The Hispanic American Historical Review 51, no. 4 (November 1971): 567 - 85.

Kraay, Hendrik. Race, State, and Armed Forces in Independence-Era Brazil: Bahia 1790s - 1840s. Stanford, CA: Stanford University Press, 2001.

Latrobe, Benjamin Henry Boneval. Impressions Respecting New Orleans: Diary \& Sketches. Edited by Samuel Wilson Jr. New York, NY: Columbia University Press, 1951.

Marjoribanks, Alexander. Travels in South and North America. London, UK: Simpkin, Marshall, and Company, 1853.

Martins, Francisco Gonçalves. "Edital Lavrado Pelo Chefe de Policia Da Bahia.” Revista Do Instituto Historico e Geografico Brazileiro, no. 72 (1909): 67 - 126Os Malês, Padre Etienne Ignace Brazil.

. "Interior, Bahia de Janeiro Da 1835 [Do Diario Da Bahia]." Diario de Pernambuco 8 (11 February 1835): 1 - 3.

Mattoso, Katia M. de. Bahia: A Cidade Do Salvador e Seu Mercado No Século XIX. Estudos Brasileiros. Salvador, Brazil: Secretaria Municipal de Educação e Cultura, 1978.

Mendes, Luís Antônio de Oliveira. "Discurso Preliminar, Historico, Introductivo Com Natureza de Descripção Economica Da Comarca e Cidade Da Bahia..” Anais Da Biblioteca Nacional Do Rio de Janeiro 27 (1905): 281 - 348. 
Mintz, Sidney W. Sweetness and Power: The Place of Sugar in Modern History. New York, NY: Penguin Books, 1985.

"Miró's Bando de Beun Gobierno." No. 1. Vol. 3, Records and Deliberations of the Cabildo, 1769 - 1803. Louisiana Division. New Orleans, LA: New Orleans Public Library, 1786.

Monkkonen, Eric H. America Becomes Urban: The Development of U.S. Cities and Towns, 1780 - 1980. Oakland, CA: University of California Press, 1990.

Morgan, Edmund. American Slavery, American Freedom: The Ordeal of Colonial Virginia. New York, NY: W.W. Norton and Company, 1975.

Morton, F.W.O. "Growth Innovation: The Bahian Sugar Industry, 1790 - 1860." Canadian Journal of Latin American and Caribbean Studies 5, no. 10 (1980): 37 -54 .

Mosher, Jeffrey Carl. "Pernambuco and the Construction of the Brazilian Nation-State, 1831 - 1850.” Ph.D. diss. Gainesville, FL: University of Florida, 1996.

Nascimento, Anna Amélia Vieira. Dez Freguesias Da Cidade Do Salvador: Aspectos Socias e Urbanos Do Século XIX. Salvador, BA: Fundação Cultural do Estado da Bahia, 1986.

New Orleans. A Digest of the Ordinances and Resolutions,by the General Council of the City of New Orleans. New Orleans, LA: J. Bayon, 1831.

A Digest of the Ordinances, Resolutions, by-Laws, and Regulations of the Corporation of New Orleans, and a Collection of the Laws of the Legislature Relative to the Said City. New Orleans, LA: G. Brusle, 1836.

A General Digest of the Ordinances and Resolutions of the Corporation of NewOrleans. New Orleans, LA: Jerome Bayon, 1831.

" "An Ordinance Concerning the Organization of the City-Watch." In A Digest of the Ordinances, Resolutions, by-Laws, and Regulations of the Corporation of

New Orleans, and a Collection of the Laws of the Legislature Relative to the Said City. In A Digest of the Ordinances, Resolutions, by-Laws, and Regulations of the Corporation of New Orleans, and a Collection of the Laws of the Legislature

Relative to the Said City, 105 - 15. New Orleans, LA: G. Brusle, 1836.

. Ordinances Issued by the City Council of New-Orleans: From the Promulgation of the Police Code Until the First of January 1812, with Two Acts of the Territorial Legislature, Relative to Said City, to Serve as a Supplement to the Police Code. New Orleans, LA: Printed by Thierry, 1812.

. Ordinances Ordained and Established by the Mayor \& City Council of the City of New Orleans. New Orleans, LA: J.C. de St. Romes, 1817.

Règlement General de Police: Pour la Ville et Banlieue de la Nouvelle-Orléans. New Orleans, LA: Jean Renard, 1805. 
Nicholas, Louis. "Rapport Du 11 Au 12 9bre 1814.” Charles F. Heartman Collection 1724 - 1897. Suite 319, Building 38, Xavier University of Louisiana, 1 Drexel Drive, New Orleans, LA 70125, 1814.

Nishida, Mieko. Slavery and Identity: Ethnicity, Gender, and Race in Salvador, Brazil, 1808 - 1888. Bloomington, IN: Indiana University Press, 2003.

Novak, William J. The People's Welfare: Law and Regulation in Nineteenth Century America. Chapel Hill, NC: University of North Carolina Press, 1996.

Palma, Alcides Passos, ed. História Da Polícia Civil Da Bahia. Bahia, BA: Governo do Estado, 1978.

Paquette, Robert L. “'A Horde of Brigands?': The Great Louisiana Slave Revolt of 1811 Reconsidered.” Historical Reflections/Réflexions Historiques 35 (2009): 72 - 96.

"Parte Geral Da Guarda Policial, Quartel Em S Bento 14 de Março de 1837." Mapas Diários. Maço 6301. Correspondencia recebida da Guarda Policial (1832 - 1839). Salvador, BR: Arquivo Público do Estado da Bahia, 1837.

"Parte Geral Da Guarda Policial, Quartel Em S Bento 16 de Julho de 1837." Mapas Diários. Maço 3059. Guarda Urbana. Salvador, BR: Arquivo Público do Estado da Bahia, 1837.

"Parte Geral Da Guarda Policial, Quartel Em S Bento 6 de Junho de 1837." Mapas Diários. Maço 6301. Correspondencia recebida da Guarda Policial (1832 - 1839). Salvador, BR: Arquivo Público do Estado da Bahia, 1837.

“Parte Geral Da Guarda Policial.” Mapas Diários. Maço 3059, Maço 6301. Guarda Urbana, Correspondencia recebida da Guarda Policial (1832 - 1839). Salvador, BR: Arquivo Público do Estado da Bahia, 1837.

Paxton, John Adams. The New-Orleans Directory and Register. New Orleans, LA: J.A. Paxton, 1822.

Piccato, Pablo. City of Suspects: Crime in Mexico City 1900 - 1931. Durham, NC: Duke University Press, 2001.

Pirspond, James. New Orleans 29 June 1821. Charles F. Heartman Collection 1724 1897. Suite 319, Building 38, Xavier University of Louisiana, 1 Drexel Drive, New Orleans, LA 70125, 1821.

Pitot, James. The Municipal Body. To All the Inhabitants of the City and Precincts of New-Orleans. Early American Imprints, Series 2, No. 9007. New Orleans, LA, 1805.

. Observations of the Colony of Louisiana from 1769 to 1802. Translated by Henry C. Pitot. Baton Rouge, LA: The Historic New Orleans Collection by the Louisiana State University Press, 1979.

Police Code, or Collection of the Ordinances of Police Made by the City Council of New Orleans. New Orleans: Printed by J. Renard, Printer, 1808. 
“Portaria." Registro de Portarias (1847 - 1849). Maço 5622. Policia. Salvador, BR: Arquivo Público do Estado da Bahia, 1847.

"Proceedings of the Conseil de Ville." 8: 24 - 25. Louisiana Division. New Orleans Public Library.

Public Lands. Vol. V of American State Papers. Washington D.C.: Gales \& Seaton, 1860.

Rasmussen, Daniel. American Uprising: The Untold Story of America's Largest Slave Revolt. New York, NY: HarperCollins Publishers, 2011.

Registro de Portarias (1847 - 1849). Maço 5622. Policia. Salvador, BR: Arquivo Público do Estado da Bahia, 1847.

Reis, João José. Rebelião Escrava No Brasil: A História Do Levante Dos Malês Em 1835. São Paulo, SP: Companhia Das Letras, 1986.

. Slave Rebellion in Brazil: The Muslim Uprising of 1835 in Bahia. Arthur Brakel. Arthur Brakel. Baltimore, MD: John Hopkins University Press, 1993.

. "'The Revolution of the Ganhadores': Urban Labour, Ethnicity and the African Strike of 1857 in Bahia, Brazil.” Journal of Latin American Studies 29, no. 2 (May 1997): 355 - 93.

Reis, João José, and Hendrik Kraay. "The Tyrant is Dead': The Revolt of the Periquitos in Bahia, 1824." Hispanic American Historical Review 89, no. 3 (2009): 399 434.

"Report of the Captain of the Guards." Charles F. Heartman Collection 1724 - 1897. Suite 319, Building 38, Xavier University of Louisiana, 1 Drexel Drive, New Orleans, LA 70125, 1809.

"Report of the Captain of the Guards." Report of December 12, 1809. Charles F. Heartman Collection 1724 - 1897. Suite 319, Building 38, Xavier University of Louisiana, 1 Drexel Drive, New Orleans, LA 70125, 1809.

"Report of the Captain of the Guards." Rapport de la Garde de L'Hotel de Ville Du 7 au 8 Novembre 1814. Charles F. Heartman Collection 1724 - 1897. Suite 319, Building 38, Xavier University of Louisiana, 1 Drexel Drive, New Orleans, LA 70125, 1814.

"Report of the Captain of the Guards." Rapport du 20 au 21 September 1814. Charles F. Heartman Collection 1724 - 1897. Suite 319, Building 38, Xavier University of Louisiana, 1 Drexel Drive, New Orleans, LA 70125, 1814.

"Report of the Captain of the Guards." Rapport du 29 au 30 Aout 1814. Charles F. Heartman Collection 1724 - 1897. Suite 319, Building 38, Xavier University of Louisiana, 1 Drexel Drive, New Orleans, LA 70125, 1814. 
"Report of the Captain of the Guards." Rapport de 18 au 19 May 1814. Charles F. Heartman Collection 1724 - 1897. Suite 319, Building 38, Xavier University of Louisiana, 1 Drexel Drive, New Orleans, LA 70125, 1814.

"Report of the Captain of the Guards." Rapport du 24 au 25 Janvier 1814. Charles F. Heartman Collection 1724 - 1897. Suite 319, Building 38, Xavier University of Louisiana, 1 Drexel Drive, New Orleans, LA 70125, 1814.

"Report of the Captain of the Guards." Charles F. Heartman Collection 1724 - 1897. Suite 319, Building 38, Xavier University of Louisiana, 1 Drexel Drive, New Orleans, LA 70125, 1814.

"Report of the Captain of the Guards." Charles F. Heartman Collection 1724 - 1897. Suite 319, Building 38, Xavier University of Louisiana, 1 Drexel Drive, New Orleans, LA 70125, 1814.

"Report of the Captain of the Guards." Charles F. Heartman Collection 1724 - 1897. Suite 319, Building 38, Xavier University of Louisiana, 1 Drexel Drive, New Orleans, LA 70125, 1824.

"Report of the Captain of the Guards." Jun - Dec. Louisiana Division/City Archives. New Orleans Public Library, 219 Loyola Ave., New Orleans, LA 70112, 1834.

"Report of the Captain of the Guards." Jan - Mar. Louisiana Division/City Archives. New Orleans Public Library, 219 Loyola Ave., New Orleans, LA 70112, 1834.

"Report of the Captain of the Guards." April - May. Louisiana Division/City Archives. New Orleans Public Library, 219 Loyola Ave., New Orleans, LA 70112, 1834.

Richardson, James F. Urban Police in the United States. London, UK, 1974.

Rodriguez, Junius. "Rebellion on the River Road: The Ideology and Influence of Louisiana's German Coast Slave Insurrection of 1811." In Antislavery Violence: Sectional, Racial, and Cultural Conflict in Antebellum America, John R. Mckivigan and Stanley Harrold, 65 - 88. Knoxville, TN: The University of Tennessee Press, 1999.

Rothman, Adam. Slave Country: American Expansion and the Origins of the Deep South. Cambridge, MA: Harvard University Press, 2005.

Rousey, Dennis Charles. Policing the Southern City: New Orleans 1805 - 1889. Baton Rouge, LA: Louisiana State University Press, 1997.

Schafer, Judith Kelleher. Becoming Free, Remaining Free: Manumission and Enslavement in New Orleans, 1846 - 1862. Baton Rouge, LA: Louisiana State University Press, 2003.

Slavery, The Civil Law, and the Supreme Court of Louisiana. Baton Rouge, LA: Louisiana State University Press, 1994.

Schultz, Kirsten. Tropical Versailles: Empire, Monarchy, and the Portuguese Royal Court in Rio de Janeiro, 1808 - 1821. New York, NY: Routledge, 2001. 
Schwartz, Stuart B. Sugar Plantations in the Formation of Brazilian Society: Bahia, 1550 - 1835. Cambridge, UK: Cambridge University Press, 1985.

Scott, Rebecca J. "Paper Thin: Freedom and Re-Enslavement in the Diaspora of the Haitian Revolution." Law and History Review 29, no. 4 (November 2011): 1061 88.

- "Slavery and the Law in Atlantic Perspective: Jurisdiction, Jurisprudence, and Justice." Law and History Review 29, no. 4 (November 2011): 915 - 24.

Sibley, John. An Account of Louisiana Laid Before Congress by Direction of the President of the United States November 14, 1803. Providence, RI: Heaton \& Williams, 1803.

Smith, Gene Allen. The Slaves' Gamble: Choosing Sides in the War of 1812. New York, NY: Palgrave Macmillan, 2013.

Spear, Jennifer M. Race, Sex, and Social Order in Early New Orleans. Baltimore, MD: The Johns Hopkins University Press, 2007.

"Squire - the Outlaw?" The Picayune, 19 July 1837, 2.

Stoddard, Amos. Sketches, Historical and Descriptive of Louisiana. Philadelphia, PA, 1812.

Suixaz, João Lourenço. João Lourenço Suixaz to Prezidente do Provincia. Juizes de Paz 1 Vara. Arquivos Do Estado Do Bahia. Salvador, BA, 1831.

—. João Lourenço Suixaz to Prezidente do Provincia. Juizes de Paz 1 Vara. Arquivos Do Estado Do Bahia. Salvador, BA, 1831.

Tannenbaum, Frank. Slave and Citizen: The Negro in the Americas. Boston, MA: Beacon Press, 1946.

Upton, Dell. Another City: Urban Life and Urban Spaces in the New American Republic. New Haven, CT: Yale University Press, 2008.

U.S. Census. Fifth Decennial Census. Washington, D.C.: Duff Green, 1831.

—. Fourth Decennial Census. Washington, D.C.: Gales \& Seaton, 1821.

—. Seventh Decennial Census. Washington, D.C.: Duff Green, 1851.

—. Sixth Decennial Census. Washington, D.C.: Duff Green, 1841.

—. Third Decennial Census. Washington, D.C.: U.S. Government Printing Office, 1811.

US Government. Census, 1810.

Wade, Richard C. Slavery in the Cities: The South 1820 - 1860. New York, NY: Oxford University Press, 1964. 
Wagner, Bryan. Disturbing the Peace: Black Culture and the Police Power After Slavery. Cambridge, MA: Harvard University Press, 2009.

Wegmann, Andrew N. "No Ordinary, No Earthly Scene: Know-Nothingism and the Death of Congo Square." Social Identities: A Journal for the Study of Race, Nation, and Culture 35, no. 3 (Fall 2012): 34 - 59.

Wilentz, Sean. The Rise of American Democracy: Jefferson to Lincoln. New York, NY: W.W. Norton and Company, 2005.

Wood, Gordon S. Empire of Liberty: A History of the Early Republic, 1789 - 1815. New York, NY: Oxford University Press, 2009. 
VITA

GREGORY KENT WEIMER

Born, Youngstown, Ohio

2001-2005

B.A., History

Ohio University

Athens, Ohio

2005-2007

M.A., History

Youngstown State University

Youngstown, Ohio

2006-2007

2008-2015

2008-2012

Research and Teaching Assistant

Youngstown State University

Youngstown, Ohio

Ph.D., History

Florida International University

Miami, Florida

Teaching Assistant

Florida International University

Miami, Florida

2012-2013

Doctoral Evidence Acquisition Fellow

Florida International University

Miami, Florida

$2013-2014$

Teaching Assistant

Florida International University 
Miami, Florida

2014-2015

Dissertation Year Fellow

Florida International University

Miami, Florida

\section{PUBLICATIONS AND PRESENTATIONS}

"Review: Diplomacy in Black and White: John Adams, Toussaint Louverture, and Their Atlantic World Alliance," Journal of the Early Republic 34, no. 4 Winter: $680-83$.

Presented, "Slavery in the City Codes: Early-Nineteenth New Orleans and Salvador" at Louisiana Historical Association, Lafayette, Louisiana, March 6, 2015.

Presented, “'Prefer Death to such a Life as they deemed Slavery': Rex v. Corbet, Impressment, and Discourses of Power in Colonial America" at British Scholar's Conference at University of Texas - Austin, Texas, March 31, 2011. Editor-in-Chief, Atlantic Millennium, 2009-2011. 